
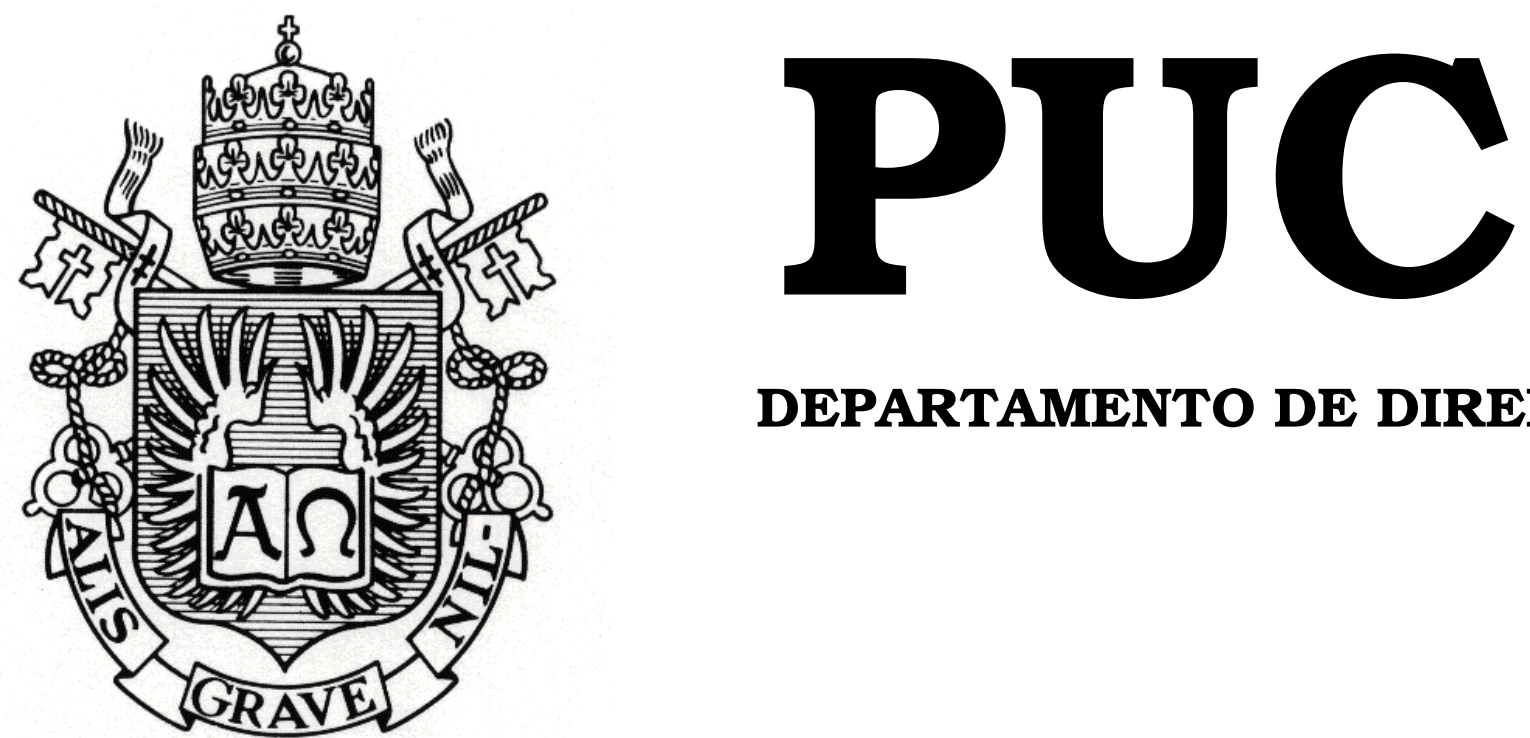

DEPARTAMENTO DE DIREITO

\title{
A FORÇA VINCULANTE DA CLÁUSULA COMPROMISSÓRIA: ANÁLISE DA SENTENÇA ESTRANGEIRA CONTESTADA №. 1
}

por

THAYSA PANZA DE PAULA

ORIENTADORA: NADIA DE ARAUJO

2012.2

PONTIFÍCIA UNIVERSIDADE CATÓLICA DO RIO DE JANEIRO

RUA MARQUÊS DE SÃO VICENTE, 225 - CEP 22453-

900RIO DE JANEIRO - BRASIL 


\section{A FORÇA VINCULANTE DA CLÁUSULA COMPROMISSÓRIA: ANÁLISE DA SENTENÇA ESTRANGEIRA CONTESTADA No. 1}

por

THAYSA PANZA DE PAULA

Monografia apresentada ao Departamento de Direito da Pontifícia Universidade Católica do Rio de Janeiro (PUC-Rio) para a obtenção do Título de Bacharel em Direito.

Orientadora: Nadia de Araujo 
Dedicatória

À Maria do Carmo, Guilherme,

Thayana e Thales pelo exemplo de

amor, igualdade e fraternidade. 


\section{Resumo}

O presente trabalho tem como objetivo auxiliar o debate sobre o instituto da Arbitragem Internacional e o seu reconhecimento pelo ordenamento jurídico brasileiro.

Para tanto, o trabalho será dividido em duas partes principais. A primeira será um estudo teórico, discorrendo sobre o histórico do instituto da arbitragem como instrumento de solução de conflitos no âmbito internacional, e mais adiante, em um plano nacional, será abordada a conquista da arbitragem no Brasil, principalmente pelas as novidades trazidas na ocasião da promulgação da Lei de Arbitragem Brasileira em 1996, em especial, o reconhecimento da eficácia da cláusula compromissória.

A segunda parte será dedicada à análise de um caso concreto, recentemente julgado pela Corte Especial do Superior Tribunal de Justiça, que se debruçou sobre alguns pontos importantes da Arbitragem internacional. Veremos que todos os argumentos levaram a uma questão fundamental: o reconhecimento da cláusula compromissória.

\section{Palavras-chave}

Convenção Arbitral - Cláusula Compromissória - Autonomia da Vontade Homologação de Sentença Arbitral Estrangeira 


\section{Sumário}

Lista de Abreviações ........................................................................ 7

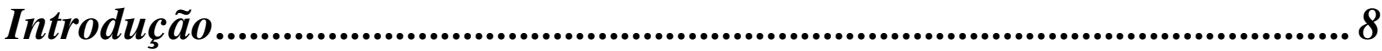

I. Parte I - Da Arbitragem......................................................... 10

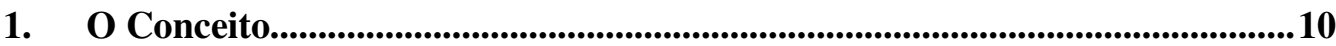

a) Arbitragem: Um breve histórico............................................................................ 11

b) O Brasil e a arbitragem internacional ..................................................................... 13

1.1 A Lei Brasileira de Arbitragem, Lei 9307/96 e as suas inovações. ......................15

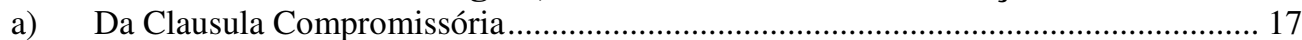

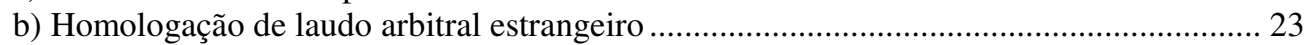

II. Parte II - Análise dos Casos Concretos........................................ 28

2. Sentença Estrangeira Contestada $N^{0} 1$ - KR (2007/0156979-5) do Superior

Tribunal de Justiça. ...................................................................................................28

2.1 Relato dos fatos:

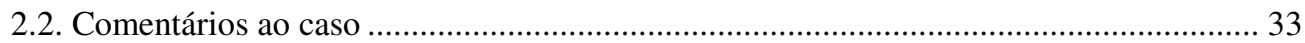

a) Superação da cláusula compromissória pelas deliberações posteriores ao Contrato de

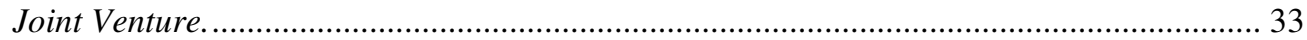

a.1) Prevalência do acordo de base nas Joint Ventures.................................................... 33

a.2) Autonomia da Cláusula Compromissória ……………………………………...... 36

b) As controvérsias levadas à apreciação do tribunal não estavam abrangidas pela

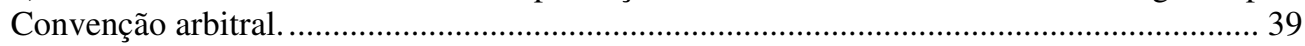

b.1) Autonomia da vontade das partes ........................................................................ 39

c) Revogação tácita da cláusula compromissória em razão da controvérsia ter sido

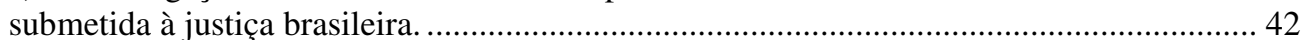

c.1) Das medidas cautelares pré-arbitrais. ................................................................. 42

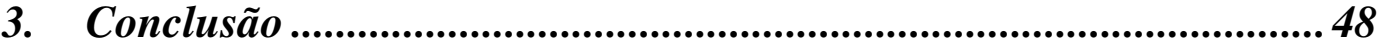

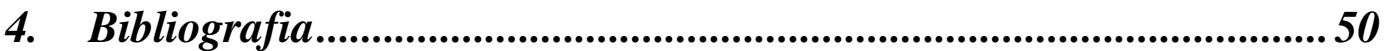

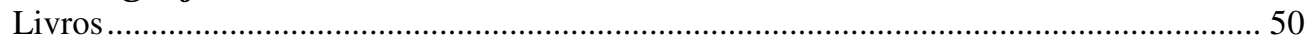

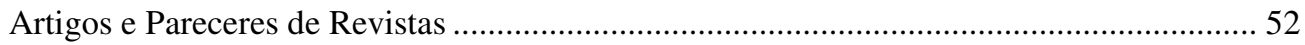

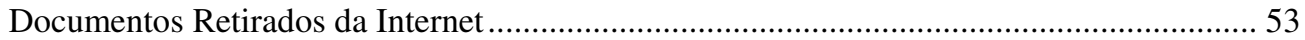

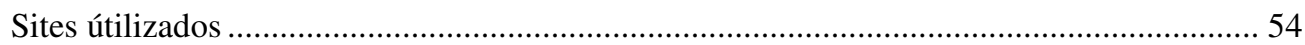

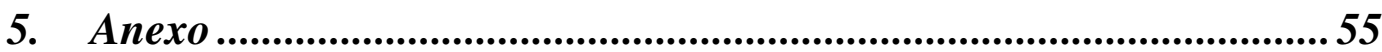



Lista de Abreviações

Art.

Artigo

CC

Código Civil de 2002

CF

Constituição Federal Brasileira de 1988

CPC

Código de Processo Civil

DJ

Diário de Justiça

LA

Lei de Arbitragem

Min.

Ministro

Rel.

Relator

SEC

Sentença Estrangeira Contestada

STJ

Superior Tribunal de Justiça

STF

Superior Tribunal Federal 


\section{Introdução}

Sem dúvida o reconhecimento da arbitragem e a sua adoção como meio alternativo de resolução de conflitos estão diretamente ligados à expansão da atividade comercial. Na medida em que as transações comerciais se intensificam, ultrapassando a fronteira da jurisdição nacional de cada uma das partes contratantes, exige-se um mecanismo capaz de acompanhar o mundo onde as fronteiras importam cada vez menos e o tempo vale cada vez mais.

Assim, apoiada em um âmbito de liberdade, onde há a prevalência da autonomia das partes, a arbitragem adquire cada vez mais relevância como mecanismo apropriado para resolução de conflitos, principalmente de natureza contratual internacional. Aspectos importantes da arbitragem, tais como a celeridade, objetividade, confidencialidade e, economia do procedimento arbitral justificam sua adoção face à complexidade, e principalmente, à morosidade do poder judiciário.

Muito embora já tivéssemos no Brasil previsão legal sobre o instituto desde o período colonial, fato é que na prática pouco se viu a sua aplicação. Foi somente com o advento da Lei 9.307/96, denominada lei de arbitragem brasileira, que a arbitragem restou definitivamente recepcionada não só como texto normativo, mas também pelos nossos tribunais.

A lei brasileira de arbitragem apresenta inovações fundamentais para a consolidação da arbitragem no Brasil, podendo destacar-se: (i) a equiparação entre a cláusula compromissória e o compromisso arbitral, como formas de composição extrajudicial de litígios; (ii) a autonomia da cláusula compromissória em relação ao contrato no qual está inserida e o princípio da Kompetenz-Kompetenz; (iii) o fim do duplo exequatur para fins de homologação de sentença estrangeira.

A lei 9.307/96, considerada o marco da arbitragem no Brasil, permitiu que empresas, principalmente as estrangeiras, adotassem a convenção arbitral em seus contratos com maior segurança em relação à 
validade da cláusula e, consequentemente, maior segurança quanto à eficácia da arbitragem. Afinal, a eficácia da arbitragem é a sua razão de $\operatorname{ser}^{1}$.

Não descartamos a necessidade de ajustes em diversas questões acerca do tema, presentes nos debates da sociedade arbitral. Tendo em vista que mas o inconformismo é imperativo para a constante atualização e aperfeiçoamento do direito, conclui-se a sua necessidade para o aprimoramento do instituto da arbitragem.

O trabalho a ser apresentado buscará auxiliar esses debates, demonstrando o posicionamento atual da doutrina e jurisprudência sobre o reconhecimento da eficácia da Arbitragem, que se dá por meio do reconhecimento da força vinculante da cláusula compromissória.

Após uma exposição predominantemente teórica na parte I, será realizada a análise de um caso concreto - SEC $\mathrm{n}^{\circ} .1$ - para uma melhor compreensão do tema. Entretanto, cabe ressaltar que esta análise está limitada aos pontos da decisão relacionados ao tema, que são a maioria, porém não todos.

\footnotetext{
${ }^{1}$ WALD, Arnoldo. A Evolução do Direito e a Arbitram. In: LEMES, Selma Ferreira; CARMONA, Carlos Alberto; MARTINS, Pedro Batista (coordenadores), Arbitragem Estudos Homenagem ao prof.. Guido Fernando da Silva Soares, In Memoriam; São Paulo. Ed. Atlas S.A., p. 458. 2007.
} 


\section{Parte I - Da Arbitragem}

\section{1. $\underline{\text { C Conceito }}$}

O termo "arbitragem" origina-se do latim, arbiter, que significa juiz, jurado. Por meio da simples análise do significado da palavra arbitragem é possível constatar uma importante característica dessa forma de resolução de conflito - a existência da figura do árbitro. $\mathrm{O}$ árbitro possui, de certa forma, as mesmas características de um Juiz, na medida em que a sua decisão tem poder de sentença, possuindo, assim, as mesmas prerrogativas da decisão judicial.

Após a verificação da primeira característica do instituto da arbitragem, cabe de forma sintetizada conceituar o tema arbitragem. Assim, tem-se que o instituto da arbitragem pode ser definido como um processo alternativo, extrajudicial e voluntário de solução de controvérsias que versa acerca de direitos patrimoniais disponíveis. No procedimento arbitral, as partes litigantes elegem, através de um compromisso arbitral, uma ou mais pessoas denominadas árbitros, submetendo-se a decisão final por ele(s) proferida.

Nas palavras de Nadia de Araujo, "a arbitragem é um meio de solução de litígios utilizado no comércio internacional que permite uma utilização do direito, moldando-se melhor às necessidades dos atores envolvidos nessa intensa atividade ${ }^{2}$.

Já Carlos Alberto Carmona ${ }^{3}$ define esse meio alternativo de solução de controvérsia da seguinte maneira:

\footnotetext{
"A Arbitragem - meio alternativo de solução de controvérsias através da intervenção de uma ou mais pessoas que recebem seus poderes de uma convenção privada, decidindo com base nela, sem intervenção estatal, sendo a decisão destinada a mesma eficácia da sentença judicial - é

2 ARAUJO, Nadia de. Direito Internacional Privado: Teoria e Prática Brasileira. $5^{\mathrm{a} e d . ~ R i o ~ d e ~}$ Janeiro: Ed. Renovar, 2011, p. 509.

${ }^{3}$ CARMONA, Carlos Alberto. Arbitragem e Processo, um comentário à Lei $n^{o}$. 9.307/96. $3^{\text {a }}$. ed. São Paulo: Ed. Atlas S.A., 2009. p. 37.
} 
colocada à disposição de quem quer que seja, para solução de conflitos relativos a direitos patrimoniais acerca dos quais os litigantes possam dispor. Trata-se de mecanismo privado de solução de litígios, por meio do qual um terceiro escolhido pelos litigantes, impõe sua decisão, que deverá ser cumprida pelas partes".

Por meio desta definição de arbitragem, é possível extrair as suas principais características: a primeira delas é o fato de ser considerada um meio alternativo de solução de conflito. Essa denominação "meio alternativo de solução de conflito" nasce do fato da arbitragem fugir da via tradicional de solução de conflito, qual seja, o Poder Judiciário.

Outra característica do instituto da arbitragem vem a ser a intervenção de um terceiro na resolução da lide, o qual não se vincula a qualquer função estatal. Ou seja, a controvérsia é retirada da esfera judicial e levada à esfera privada, onde um particular - árbitro ou tribunal arbitral recebe a prerrogativa de solucionar o litígio, proferindo uma decisão cujo cumprimento é obrigatório às partes.

Percebe-se das mencionadas características, que estas são concretizadas através da convenção arbitral, onde as partes determinam sobre a escolha da arbitragem como instrumento de resolução dos conflitos. A convenção formaliza a vontade das partes.

Por fim, a terceira característica que podemos extrair do professor Carmona é a necessidade da disponibilidade do direito patrimonial a ser levado à arbitragem. Dessa forma, só poderá ser solucionado por meio da arbitragem, um litígio que envolva um direito patrimonial disponível.

Expostas as características basilares da arbitragem, a seguir, veremos a arbitragem no mundo e no Brasil.

\section{a) Arbitragem: Um breve histórico}

O conceito de arbitragem como método de resolução pacifica de conflitos, pode ser considerado tão antigo como a ciência do Direito. Desde a Grécia antiga, já era possível reconhecer o instituto da arbitragem na 
mitologia, que atribuiu ao juízo de paz a primeira forma de arbitragem que existiu na história da civilização. Já na polis, a figura do árbitro era prevista para resolução de conflitos, tendo como função, em um primeiro momento, a busca pela conciliação e, em seguida, o julgamento do litígio por meio da equidade

Mais precisamente no ano de 445 a.C., época de surgimento das Cidades-Estado, constata-se a $1^{\mathrm{a}}$ manifestação de cláusula compromissória prevista no tratado de paz firmado entre Espatas e Atenas, evidenciando a utilização da arbitragem já naquela época.

A idade média também teve o seu papel no desenvolvimento da arbitragem $^{5}$, sendo esta utilizada para solucionar controvérsias entre comerciantes, com base em uso e costumes e demais práticas comerciais existentes à época. Aqui, comerciantes indicavam um terceiro comerciante para decidir sobre as questões advindas da relação comercial, assim, o terceiro escolhido, determinava o valor da mercancia envolvida. Nesse momento, já se atribuiu a cláusula compromissória aos contratos comerciais.

Entretanto, é no final do século XVIII, diante do cenário da Revolução Francesa que a arbitragem é acolhida como instrumento de reação contra os abusos cometidos pela justiça real ${ }^{6}$, sendo, inclusive, prevista no Código de Processo Civil Francês promulgado em $1806^{7}$ :

"1010. Lorsque l'arbitrage será sur appel ou sur requête civile, le jugement arbitral sera definitif et sans appeal."

\footnotetext{
4 “Aristóteles, na retórica (I,13,1974b, 420) confirma que o árbitro visa à equidade, enquanto o juiz visa à lei" - CRETELLA Neto, José. Curso de Arbitragem. $1^{\mathrm{a}}$ Ed., Rio de Janeiro: Ed. Forense, 2004, p.6-7.

${ }^{5}$ Nota-se que a arbitragem precede a ideia de Estado como organização estatal, que surge entre os séculos XVII e XVIII.

${ }^{6}$ Oporto Fazzinga, Silva e Vasconcellos, Fernando. Arbitragem Comercial Internacional. Disponível em < http://sisnet.aduaneiras.com.br/lex/doutrinas/arquivos/080306t.pdf $>$. Acesso em 30 de set. 2012.

${ }^{7}$ Code de Procédure Civile, edition originale et seule officielle, L'imprimerie impériale, 1806. Coleção da Universidade de Michigan - download de cópia integral diponibilizado pelo Google Google books service. Tradução livre: "Quando a arbitragem se der por meio de recurso ou pedido civil, a sentença arbitral será definitivada e irrecorrível."
} 
Caminhando para um cenário internacional, as Convenções da Haia de 1899 e 1907 (ambas sobre a Resolução Pacífica de Controvérsias Internacionais) tiveram papel fundamental na regulação da arbitragem ao criarem a Corte Permanente de Arbitragem ("CPA"). Igualmente importante, cria-se em 1919, a Câmara de Comércio Internacional (“CCI”), marco para um sistema arbitral mais independente e universal, capaz de dispor sobre controvérsias entre países distintos.

\section{b) O Brasil e a arbitragem internacional}

Não há tradição no Brasil do uso da arbitragem para solucionar conflitos. Entretanto, desde a época da Colônia, esta já se encontrava prevista nas Ordenações Filipinas, com a existência da figura do Juiz árbitro e dos Arbitradores.

Em ambiente puramente brasileiro, tem-se o seu reconhecimento previsto na Constituição Federal de 1824 , em seu artigo $160^{8}$ que previa a possibilidade das partes optarem por um juiz-árbitro para solucionar o litígio, tanto nas ações cíveis quanto "nas penais civilmente intentadas". Posteriormente, o Código Comercial de 1850 estabelecia a obrigatoriedade da arbitragem em assuntos comerciais. Contudo, até pouco tempo atrás a legislação brasileira não favorecia a prática da arbitragem, porquanto o código de processo civil não conferia à cláusula compromissória, mas tão somente ao compromisso ${ }^{9}$, os efeitos de afastar o juízo estatal e de instituir a arbitragem ${ }^{10}$.

\footnotetext{
${ }^{8}$ Art. $160 \mathrm{CF} / 1824$. "Nas cíveis, e nas penais civilmente intentadas poderão as Partes nomear Juízes Árbitros. Suas Sentenças serão executadas sem recurso, se assim o convencionarem as mesmas Partes".

${ }^{9}$ A cláusula compromissória antecede ao conflito, é definida para o surgimento de um futuro conflito, já o compromisso arbitral exige a existência efetivada da disputa, o compromisso nasce com o conflito.

${ }^{10}$ LOBO, C. A. da Silveira. Uma introdução à arbitragem comercial internacional. In: ALMEIDA, Ricardo Ramalho (org.). Arbitragem interna e internacional: questões de doutrina e da prática. Ed. Renova, 2003, p.5
} 
A arbitragem também foi prevista pelo Código Civil, de 1916, em seus artigos 1037 a 1048, que determinavam a irrecorribilidade da sentença arbitral, e ainda, que na existência de compromisso escrito entre as partes designando um árbitro, o contrato seria válido, afastando o Poder Judiciário.

A partir do inicio da vigência do Código Civil de 1916 é possível destacar a aplicação da arbitragem na solução de litígios complexos, como foi o caso conhecido como "Companhia Siderúrgica Nacional x Augusto Batista Pereira", envolvendo a exploração de mina de carvão no Estado de Santa Catarina ${ }^{11}$, cujo contrato em discussão data de 1947.

Confira-se:

Juízo Arbitral - Compromisso - Apelação da Sentença Homologatória Renúncia Não basta, para que se considere a decisão como contrária ao direito expresso, a eventualidade de erro na interpretação da lei; ou na aplicação da norma legal aos fatos provados. É de mister tenha sido violada a norma legal expressa, e não apenas eleita uma de duas ou mais interpretações possíveis da mesma norma. Salvo esse caso excepcional, não é possível substituir a decisão do Tribunal à do árbitro escolhido pelas próprias partes.

A Companhia Siderúrgica Nacional, sociedade anônima estabelecida na Capital Federal, à avenida Nilo Peçanha nº 31 e os engenheiros José Batista Pereira e Augusto Batista Pereira, o primeiro residente em Porto Alegre e o segundo nesta Capital, resolveram submeter a este juízo arbitral as divergência surgidas entre eles e a propósito do contrato de locação de serviços, firmado a 22 de maio de 1947, com o prazo de quatro anos, já extinto.

Não obstante a previsão da arbitragem no ordenamento jurídico brasileiro desde a Constituição de 1837 , não se pode ignorar os seus obstáculos como a falta de executoriedade da cláusula compromissória, vista meramente como uma "obrigação de fazer", a dificuldade imposta pela legislação no que versava sobre o reconhecimento e execução de sentenças arbitrais estrangeiras, e a ausência de lei específica sobre o tema. Inúmeros obstáculos que impedem à aplicação apropriada da arbitragem.

Há autores que entendem que a razão para a não aplicabilidade da arbitragem à pratica de solução de conflitos no Brasil seria a tradição

${ }^{11}$ Revista Forense, Rio de Janeiro, v. 15, 195, p. 239 
nacional de confiar no Estado como único ente capaz de dirimir os problemas da sociedade e desconfiar dos atos praticados por particulares em geral. Essa relutância, na visão de alguns, configurou uma barreira para a expansão da arbitragem.

Para Pedro A. Batista Martins ${ }^{12}$, existe no Brasil o "primado do Estado sobre o indivíduo", ou "paternalismo estatal", consubstanciando exacerbada inclinação da coletividade ao Estado como espécie de salvação única para os problemas individuais e da coletividade, que muitas vezes afasta o princípio da autonomia da vontade das pessoas.

Entretanto, percebe-se uma mudança deste cenário nas últimas décadas. A promulgação da Lei no ${ }^{\circ}$ 9.307, de 23 de setembro de 1996, mais conhecida como a Lei Brasileira de Arbitragem e o reconhecimento da sua constitucionalidade pelo Supremo Tribunal Federal ${ }^{13}$ são alguns exemplos. Além disso, em 2002 o Brasil ratificou a Convenção de Nova Iorque de 1958, e a introduziu no ordenamento jurídico pátrio. Tais acontecimentos configuram um marco importante para a consolidação da arbitragem no país.

\title{
1.1 A Lei Brasileira de Arbitragem, Lei $9307 / 96$ e as suas inovacões.
}

Sem dúvida o marco do reconhecimento da arbitragem no Brasil foi a promulgação da Lei Brasileira de Arbitragem de 1996, que finalmente passou a disciplinar a arbitragem no Brasil.

Segundo Pedro A. Batista Martins ${ }^{14}$ :

\begin{abstract}
"A Lei de Arbitragem é a convergência da democratização social com os novos direitos sociais, voltados para a efetividade e solidariedade. É lei cidadã, que permeia o inconsciente social, o consenso e a solidariedade. Instiga a ética e a moral. Agiliza e possibilita o exercício de direito
\end{abstract}

\footnotetext{
${ }^{12}$ CARMONA, Carlos Alberto. Arbitragem e Processo, um comentário à Lei $n^{o}$. 9.307/96. $3^{\mathrm{a}}$. ed. São Paulo: Ed. Atlas S.A., 2009. p. 45.

${ }^{13}$ BRASIL, Supremo Tribunal Federal, Agravo Regimental na Sentença Estrangeira no. 5.206, Rel. Min. Sepúlveda Pertence, .julgamento em 12.12.2001.

${ }^{14}$ MARTINS, Pedro A. Batista. Apontamentos sobre a lei de arbitragem. Rio de Janeiro: Ed. Forense, 2008, introdução.
} 
natural do cidadão, isto é, o acesso à justiça. Confirma e reforça o sentido de cidadania pela cooperação do cidadão comum com o Estado, na importante tarefa de pacificação dos conflitos. Atende, enfim, ao devido processo substantivo

Daí não ser a Lei Marco Maciel mais um simples conjunto de dispositivos legais. É mais. É muito mais! É o início de nova cultura de uma sociedade participativa, ciosa de seus direitos, mas, sobretudo, consciente de seus deveres. A arbitragem traduz esse espírito secular. É o povo exercendo, em sua plenitude, seus direitos com responsabilidade. Com liberdade. Com respeito. Enfim, com cidadania".

Nesse mesmo sentido, diz Carmona ${ }^{15}$ :

"A Lei de Arbitragem trouxe a esperança de revitalização do instituto no Brasil. A arbitragem, que poderá ser utilizada para solução de controvérsias que envolvam direitos patrimoniais disponíveis, ressurge, com a nova lei, não apenas como mei alternativo de solução de conflitos, mas como forma eficaz de amenizar os problemas com o acesso à justiça, o que poderá propiciar, em curto período de tempo, o aumento da credibilidade do ordenamento jurídico brasileiro, seja no âmbito interno, seja no âmbito internacional, num momento em que a Justiça Estatal encontra-se sob profunda crise.

Isso porque, a Lei 9.307/96, ao alterar o instituto da arbitragem, procura proporcionar maior praticidade ao procedimento, tentando resolver questões que tornavam imprestável a utilização do juízo arbitral como meio alternativo de pacificação de conflitos. Nesse sentido, o legislador fortaleceu a cláusula compromissória, que, até então, quase não produzia efeitos. Prezou ainda, pela desnecessidade de homologação das decisões judiciais, assemelhando as sentenças arbitral e estatal, e pôs fim ao sistema de dupla homologação, por meio do qual o Supremo Tribunal Federal não homologava laudos arbitrais estrangeiros, sem que, antes, o executado obtivesse o exequatur da justiça do país onde o laudo fora proferido.

A Lei de Arbitragem introduziu questões fundamentais, capazes de modificar radicalmente a estrutura da arbitragem no país. Uma delas se refere ao estabelecimento da chamada convenção de arbitragem, cujas espécies são o compromisso arbitral e a cláusula compromissória ${ }^{16}$.

\footnotetext{
${ }^{15}$ CARMONA, Carlos Alberto. A arbitragem no Brasil no terceiro ano de vigência da Lei n. ${ }^{\circ}$ 9.307/96. In: PUCCI, Adriana Noemi (Coord.). Aspectos atuais da arbitragem: coletânea de artigos dos árbitros do Centro de Conciliação e Arbitragem da Câmara de Comércio ArgentinoBrasileira de São Paulo. Rio de Janeiro: Ed. Forense, 2001. p. 45.

${ }^{16}$ Art. $3^{\circ}$, L. 9.307/96: As partes interessadas podem submeter a solução de seus litígios ao juízo arbitral mediante convenção de arbitragem, assim entendida a cláusula compromissória e o compromisso arbitral.
} 
Outra inovação diz respeito ao acolhimento do princípio da cláusula compromissória, o que torna a sua existência independente do contrato no qual esta inserida ${ }^{17}$. Já no que se refere à sentença arbitral nacional, esta passou a ter a mesma eficácia da sentença proferida pelo Estado-Juiz, dispensando a homologação pelo Poder Judiciário ${ }^{18}$.

Assim, a lei 9.307/96 tem sua importância cravada na evolução da arbitragem no Brasil, não somente pelas matérias acolhidas, mas também devido às inovações apresentadas.

\section{a) Da Clausula Compromissória}

Conforme já mencionado, uma das principais inovações advindas da Lei Brasileira de Arbitragem decorreu do estabelecimento da Convenção de Arbitragem, equiparando a cláusula compromissória e o compromisso arbitral, como formas de composição extrajudicial de disputas, sejam elas presentes ou futuras a um ou diversos árbitros, cuja adoção exclui a causa do âmbito do processo jurisdicional.

Em uma breve síntese, Carlos Alberto Carmona ${ }^{19}$ entende que a nova lei trouxe a Convenção de Arbitragem com duas principais características, conforme dispõe:

“(...) a convenção de arbitragem tem duplo caráter: como acordo de vontades, vincula as partes no que se refere a litígios atuais ou futuros, obrigando-as reciprocamente à submissão ao juízo arbitral; como pacto processual, seus objetivos são os de derrogar a jurisdição estatal, submetendo as partes à jurisdição dos árbitros. Portanto, basta a convenção de arbitragem (cláusula ou compromisso) para afastar a competência do juiz togado (...)"

\footnotetext{
${ }^{17}$ Art. 8º, L. 9.307/96: A cláusula compromissória é autônoma em relação ao contrato em que estiver inserta, de tal sorte que a nulidade deste não implica, necessariamente, a nulidade da cláusula compromissória.

${ }^{18}$ Art. 31, L. 9.307/96: A sentença arbitral produz, entre as partes e seus sucessores, os mesmos efeitos da sentença proferida pelos órgãos do Poder Judiciário e, sendo condenatória, constitui título executivo.

${ }^{19}$ CARMONA, Carlos Alberto. Arbitragem e Processo, um comentário à Lei $n^{o}$. 9.307/96. $3^{\mathrm{a}}$. ed. São Paulo: Ed. Atlas S.A., 2009. p. 79.
} 
Referida lei estabeleceu, portanto, um procedimento judicial para forçar a implementação da arbitragem. Dessa forma, constituída a convenção arbitral, produz-se desde logo seus efeitos de afastar o juízo estatal, atribuindo a jurisdição aos árbitros.

Ressalte-se ainda que a Lei Brasileira de Arbitragem faz distinção entre a cláusula compromissória e o compromisso arbitral. Assim, se as partes quiserem submeter a solução do seu litígio à arbitragem, estas devem criar uma convenção de arbitragem, que será uma cláusula compromissória inserida no contrato ou, quando já surgido o litígio, um compromisso arbitral. Referida distinção encontra-se prevista no artigo $7^{\circ}$ da referida $1 \mathrm{ei}^{20}$.

Dessa forma, tem-se que a principal diferença entre a cláusula compromissória e o compromisso arbitral é que este se refere a um litígio presente, ao passo que aquela, pressupõe-se anterior a qualquer conflito, conforme definição do Superior Tribunal de Justiça ${ }^{21}$ : Vale observar que tanto a cláusula quanto o compromisso passaram a produzir o mesmo efeito, não havendo muito interesse em tal distinção.

A diferença entre as duas formas de acordo versa no fato de que, enquanto o compromisso arbitral se destina a submeter ao juízo arbitral uma controvérsia concreta já surgida entre as partes, a cláusula compromissória objetiva submeter a processo arbitral apenas questões indeterminadas e futuras, que possam surgir no decorrer da execução do contrato.

Hoje a cláusula compromissória é assegurada pelos princípios da autonomia e o da Kompetenz-Kompetenz, que lhe garantem eficácia junto aos pressupostos da sua absoluta validade dispostos no artigo $8^{\circ}$ da Lei 9.307/96:

\footnotetext{
${ }^{20}$ Art. $7^{\circ}$, Lei 9.307/96: "Existindo cláusula compromissória e havendo resistência quanto à instituição da arbitragem, poderá a parte interessada requerer a citação da outra parte para comparecer em juízo a fim de lavrar-se o compromisso, designando o juiz audiência especial para tal fim."

${ }^{21}$ BRASIL. Superior Tribunal de Justiça. SEC 1.210/GB, Rel. Ministro Fernando Gonçalves, Corte Especial, julgado em 20/06/2007.
} 
"A cláusula compromissória é autônoma em relação ao contrato em que estiver inserta, de tal sorte que a nulidade deste não implica, necessariamente, a nulidade da cláusula arbitral."

Assim, tem-se como efeitos submeter à arbitragem como a solução dos litígios advindos do contrato no qual a cláusula expressa foi inserida de maneira a afastar a jurisdição estatal.

Dessa forma, abandona-se a ideia de cláusula compromissória apenas como um mero pré-contrato para realizar um compromisso, sem qualquer efeito vinculante, mas sim como uma obrigação para constituir um juízo arbitral, afastando o juízo estatal.

Entretanto, antes da cláusula compromissória gozar de autonomia prevista na legislação nacional, esta era vista como mero pré-contrato no qual as partes signatárias se comprometiam a celebrar o compromisso para haver a arbitragem e ainda não detinha execução específica, bastando a mera alegação de nulidade do contrato por uma das partes para colocar em jogo a validade da cláusula. Dessa maneira, a parte não interessada na instituição do tribunal arbitral utilizava-se desta arguição de nulidade contratual para invalidar o contrato como um todo, inclusive a cláusula, e assim dilatar o processo uma vez que a questão era levada, primeiramente, ao judiciário para decidir sobre a validade do contrato.

Diante desse cenário, o artigo $8^{\circ}$ da Lei Brasileira de Arbitragem consagra a autonomia da cláusula compromissória, bem como garante a autonomia das vontades das partes (contratantes) resguardando a escolha de manter o litígio na via arbitral e de afastar a intervenção estatal. Mencionada autonomia significa que se nulo o contrato, a clausula subsistirá, desde que não seja essencial à própria existência do acordo.

Derivam da autonomia da cláusula compromissória, duas principais consequências: a primeira é de que a convenção arbitral não é comprometida pela validade do contrato principal; ademais, a cláusula pode ser regida por lei diversa daquela que conduz o contrato principal. 
Nas palavras de Pedro Batista Martins 22 , "a autonomia da cláusula e a competência-competência atuam como verdadeiras blindagens jurídicas àqueles que buscam se afastar da obrigação assumida de submeter as controvérsias ao juízo arbitral".

No direito comparado esse princípio é bastante difundido, em especial nos países do Common Law segundo se observa das palavras de Philippe Fouchard ${ }^{23}$ :

"The principle of autonomy has been, however, expressly recognized in the statutes or case Law of a large number of countries.(...) A variety of countries, including many with a common law tradition, have implemented legislation based on the Model Law. As a result, the recognition of the principle of autonomy has become widespread." $\operatorname{Rozas}^{24}$ :

Nesse sentido, também leciona o professor José Carlos Fernández

"El carácter autónomo del convenio arbitral está establecido en la generalidad de los sistemas jurídicos a partir de los dispuestos en la Ley Modal Unicitral en el sentido de que «la cláusula compromisoria que forme parte de un contrato se considerará como un acuerdo independiente de las estipulaciones del contrato»".

A doutrina de J. C. Fernández Rozas entende que a convenção de arbitragem é uma condição adicional e diversa às condições gerais estabelecidas em um contrato. Dessa forma, a autonomia da cláusula compromissória implica na possibilidade do acordo arbitral e da resolução

\footnotetext{
22 MARTINS, Pedro Batista, Poder Judiciário-Princípio da autonomia da cláusula compromissória - princípio da competência-competência - Convenção de Nova Iorque - Outorga de poderes para firmar cláusula compromissória - determinação de lei aplicável ao conflito julgamento pelo tribunal arbitral. In: Revista de Arbitragem e Mediação Vol.7, 2005, p. 174-193.

${ }^{23}$ FOUCHARD, Philippe; GAILLARD, Emmanuel; GOLDMAN, Berthold. On International Commercial Arbitration, org. (Gaillard, Emmanuel, \& Savage, John); Kluwer Law International: Haia, 2010, p. 203-205. Tradução livre: "O Princípio da autonomia tem sido expressamente reconhecido em diversos casos de diversos países. Inúmeros países, incluindo os regidos pela tradição da Common Law, já implementaram legislação baseada na Lei Modelo UNCTIRAL. Assim, o reconhecimento do princípio da autonomia foi difundido."

${ }^{24}$ ROZAZ, J. C. Fernández; GARCÍA, Rafael Arenas; ASENSIO, Pedro Alberto de Miguel, In Derecho de los Negocios internationals. $3^{\mathrm{a}}$ edicíon, Ed. Iustel, Madrid, 2011, p.650. Tradução livre: "O caráter autônomo da convenção arbitral está determinado na maioria dos sistemas jurídicos formados a partir da Lei Modelo UNCITRAL, no sentido de considerar a cláusula compromissória como um acordo independente das estipulações dispostas no contrato."
} 
do litígio serem regulados por leis diversas daquela do contrato $^{25}$, por exemplo.

A validade e eficácia da cláusula compromissória autorizam as partes a submeteres à arbitragem os conflitos que venham a surgir relativos ao contrato, o que retira dos contratantes a opção de optarem pela demanda judicial. A inovação advinda da Lei de Arbitragem visa acelerar a solução de litígios, tendo a clausula arbitral força suficiente para afastar o ingresso da parte na justiça estatal.

O próprio STF já reconheceu a constitucionalidade da força vinculante da cláusula compromissória, como se percebe da leitura do acórdão proferido no SE $5.206 \mathrm{AgRg}^{26} \mathrm{em}$ que durante a votação do Agravo Regimental interposto contra a decisão que não homologou sentença arbitral estrangeira, foi suscitada a inconstitucionalidade da Lei $9.307 / 96^{27}$. Nas palavras do Procurador-Geral da Repúbica à época:

O legislador ordinário nacional, com a edição da lei 9.30/96, abriu o caminho para que as pessoas físicas e jurídicas capazes se valessem da arbitragem como forma de solucionar as suas controvérsias relativas a direitos patrimoniais disponíveis, sem a intervenção do Estado por meio de decisão destinada a assumir os efeitos da sentença arbitral. Vale dizer: equiparou os efeitos da sentença arbitral aos da decisão judicial em processo de conhecimento.

Sustentando a mesma posição do Procurador-Geral, enfatizou a Ministra Ellen Gracie sobre a importância da validade da cláusula compromissória para os negócios internacionais:

Negar a possibilidade a que a cláusula compromissória tenha plena validade e que enseje execução específica importa em erigir em privilégio da parte inadimplente ou furtar-se à submissão à via expedida de solução

\footnotetext{
${ }^{25}$ Tradução livre do trecho: “(...) la cláusula de arbitraje es una condición suplementaria y diversa de las condiciones generales establecidas en un contrato. Por descontado, la autonomía de la cláusula compromisoria implica que el acuerdo arbitral y el fondo de la controversia pueden regular por leyes diferentes". Cit. p.652.

${ }^{26}$ Disponível em:

$<<$ http://redir.stf.jus.br/paginadorpub/paginador.jsp?docTP=AC\&docID=345889 >> acesso em 12.10.2012.

${ }^{27}$ DOLINGER, Jacob; TIBÚRCIO, Carmen, Direito Internacional Privado (parte especial): Arbitragem Comercial Internacional; Rio de Janeiro: Ed. Renovar, 2003, p. 64
} 
da controvérsia, mecanismo pelo qual optara livremente, quando da lavratura do contrato original em que inserida essa previsão. É dar recalcitrante o poder de anular condição que - dada a natureza dos interesses envolvidos - pode ter sido consideração básica à formação da avença. É inegável que, no mundo acelerado em que vivemos, ter, ou não, acesso às fórmulas rápidas de solução das pendências resultantes do fluxo comercial, constitui diferencial significativo no poder de barganha dos contratantes."

Não obstante autonomia da cláusula compromissória, sob a influência da Lei Modelo da Unicitral sobre Arbitragem Comercial, o ordenamento jurídico brasileiro incorporou um segundo princípio, o já mencionado princípio Kompetenz-Kompetenz e, conferiu ao árbitro, dentre outras competências, àquela para decidir sobre a existência, validade e eficácia da cláusula compromissória, caso alguma dessas questões sejam suscitadas ou até mesmo de ofício ${ }^{28}$. Ou seja, se alguma dessas partes suscitar innexistência, invalidade ou ineficácia da cláusula compromissória, será do árbitro a competência para julgar.

Acerca desse assunto, o Superior Tribunal de Justiça entende pela obrigatoriedade da solução do litígio pela via arbitral, quando existente cláusula compromissória previamente ajustada entre as partes. Neste sentido, confira-se:

"Processual civil. Arbitragem. Obrigatoriedade da solução do litígio pela via arbitral, quando existente cláusula previamente ajustada entre as partes neste sentido. Inteligência dos arts. $1^{\circ}, 3^{\circ}$ e $7^{\circ}$ da lei 9.307/96. Precedentes. Provimento neste ponto. Alegada ofensa ao art. 535 do CPC. Não ocorrência. Recurso especial parcialmente provido. ${ }^{29}$

"Lei De Arbitragem - Instituição Judicial Do Compromisso Arbitral Objeto Do Litígio - Infringência A Cláusulas Contratuais - Validade Ausência De Omissão.

I - Se o acórdão recorrido aborda todas as questões submetidas à sua apreciação, não há falar em violação ao inciso II do artigo 535 do Código de Processo Civil.

II - Para a instauração do procedimento judicial de instituição da arbitragem (artigo $7^{\circ}$ da Lei n..$^{\circ}$ 9.307/96), são indispensáveis a existência

\footnotetext{
${ }^{28}$ Art. 8, §único L. 9307/96: Caberá ao árbitro decidir de ofício, ou por provocação das partes, as questões acerca da existência, validade e eficácia da convenção de arbitragem e do contrato que contenha a cláusula compromissória.

${ }_{29} 10$ BRASIL. Superior Tribunal de Justiça (terceira. turma). Resp. 791.260/RS, Rel. Min. Paulo Furtado (Desembargador Convocado Oo TJ/BA). Julgado em 22/06/2010.
} 
de cláusula compromissória e a resistência de uma das partes à sua instituição, requisitos presentes no caso concreto.

III - Tendo as partes validamente estatuído que as controvérsias decorrentes dos contratos de credenciamento seriam dirimidas por meio do procedimento previsto na Lei de Arbitragem, a discussão sobre a infringência às suas cláusulas, bem como $o$ direito a eventual indenização, são passíveis de solução pela via escolhida.

Com ressalvas quanto à terminologia, não conheço do recurso especial." ${ }^{\text {30 }}$

Como se infere do entendimento do STJ, o ordenamento jurídico brasileiro recepcionou o princípio da Kompetenz-Kompetenz em uma dualidade de efeitos: o positivo - aptidão do árbitro para decidir sobre a existência, validade e eficácia da cláusula -, e o negativo - afasta a jurisdição estatal da análise dessas controvérsias contratuais ${ }^{31}$, de tal modo que o árbitro seja o primeiro julgador.

A existência da cláusula compromissória em um contrato permite ao juízo estatal atuar apenas em situações de (i) nulidade de decisão arbitral quando o árbitro não dispuser de tal poder (ii) quando os meios pela via arbitral se esgotarem; (iii) na execução de medidas cautelares ou coercitivas quando a pedido do árbitro. Isto quer dizer que apenas em casos de exceção, onde há manifesta causa para anular sentença arbitral ou do contrato é que se cogita a atuação do poder estatal.

Deste modo, percebe-se que o princípio da autonomia assim como o principio Kompetenz-Kompetenz objetivam garantir a força vinculante da cláusula compromissória, atendendo ao que foi pactuado pelas partes.

\section{b) Homologação de laudo arbitral estrangeiro}

A independência da sentença arbitral conferida pelo artigo 18 da Lei 9.307/96, garantiu a sua plena eficácia, sem que para tal seja necessária a sua homologação pela autoridade judiciária. Assim, houve o fim da possibilidade de alteração pelo judiciário do trabalho do árbitro, que

\footnotetext{
${ }^{30}$ BRASIL. Superior Tribunal de Justiça (terceira turma). Resp. 450.881/DF, Rel. Min. CASTRO FILHO, julgamento em 11.04.2003.

${ }^{31}$ MARTINS, Pedro A. Batista. Apontamentos sobre a lei de Arbitragem, $1^{\text {a }}$ ed., Rio de Janeiro: Ed. Forense, 2008, p. 137
} 
descaracterizava por completo o efeito da agilidade com que se deseja a solução do litígio tendo em vista que, para a homologação da sentença, seria preciso aguardar os lentos trâmites judiciais.

Entretanto, para a sentença estrangeira, estatal ou arbitral, é exigido passar por um procedimento de homologação pelo STJ $^{32}$ para que sua eficácia seja reconhecida em território nacional. É que o Código de Processo Civil, enquanto lei federal exige a homologação da sentença estrangeira para que esta adquira eficácia em território brasileiro ${ }^{33}$.

O ordenamento jurídico brasileiro considera estrangeira toda sentença proferida fora do território brasileiro, adotando, assim, o princípio da territorialidade. É o que dispõe de forma expressa o artigo 34 da lei brasileira de Arbitragem, que considera "sentença arbitral estrangeira a que tenha sido proferida fora do território nacional".

Embora a ratificação da Convenção de Nova Iorque de 1958 pelo Brasil tenha ocorrido apenas no ano de 2002, percebe-se que finalmente restou consagrado o critério geográfico ${ }^{34}$ utilizado para definir se uma sentença é estrangeira, reproduzindo-se a disposição constante do artigo I.1 da $\mathrm{CNY}^{35}$.

Nas palavras do jurista Arnoldo Wald ${ }^{36}$ :

"A solução encontrada pelo legislador brasileiro foi inspirada na Convenção de Nova Iorque de 1958, assim como em outras legislações estrangeiras, como a da Espanha, que a considerou a mais adequada para a determinação da nacionalidade das sentenças arbitrais e, por conseguinte, do regime a elas aplicáveis."

\footnotetext{
${ }^{32}$ A Lei Brasileira de Arbitragem previa expressamente em seu artigo 35, a necessidade da sua homologação pelo Supremo Tribunal Federal. Entretanto, com a entrada em vigor da Emenda Constitucional $n^{\circ}$. 45, em 8 de dezembro de 2004, a competência para a homologação de sentenças estrangeiras foi deslocada do Supremo Tribunal Federal para o Superior Tribunal de Justiça.

${ }^{33}$ CARMONA, Carlos Alberto. Arbitragem e Processo, um comentário à Lei $n^{o}$. 9.307/96. $3^{\mathrm{a}}$. ed. São Paulo: Ed. Atlas S.A., 2009. p. 445.

${ }^{34}$ LEE, João Bosco. A homologação de Sentença Arbitral Estrangeira: a Convenção de Nova Iorque de 1958 e o Direito Brasileiro de Arbitragem In: LEMES, Selma Ferreira; CARMONA, Carlos Alberto; MARTINS, Pedro Batista (coordenadores), Arbitragem Estudos em Homenagem ao Prof. Guido Fernando da Silva Soares, In Memoriam; São Paulo:Ed. Atlas S.A., 2007, p.177

${ }^{35}$ A CNY de 1958 foi ratificada por 137 países e na maioria dos casos, conforme art. 34 da Lei 9.307/96, será o diploma internacional a ser aplicado no procedimento de homologação de sentença arbitral estrangeira no Brasil.

${ }^{36}$ WALD, Arnoldo, Os Meios Judiciais de Controle da Sentença Arbitral. In: Revista de Arbitragem e Medição no. 1, 2004. p 50-51
} 
Definição adotada também no direito comparado como se verifica da Lei espanhola de arbitragem, Ley de Arbitraje $/ 2003^{37}$ :

"El art. 46 LA/2003 tras reiterar la definición de laudo extranjero de la LA/1998, esto es, «el pronunciado fuera del territorio español», soluciona, de una vez por todas, el eterno problema de la dualidad de regímenes existente has la fecha en nuestro ordenamiento, y en muchos otros, como consecuencia de la observancia de la CNY de 1958."

Vale lembrar que a Lei de Arbitragem Brasileira aboliu um dos grandes obstáculos para o reconhecimento da arbitragem internacional no país: o denominado duplo exequatur ${ }^{38}$ ou dupla homologação, já abolido pela CNY de 1958. Após a entrada em vigor da lei 9.307/96, elimina-se tal limitação, exigindo-se apenas que a sentença estrangeira seja levada diretamente ao STJ para concessão do exequatur.

Os laudos arbitrais estrangeiros devem seguir um procedimento de execução que englobam duas etapas: (i) o reconhecimento da sentença arbitral; (ii) e a execução da mencionada sentença ${ }^{39}$.

A primeira etapa é a própria homologação da sentença estrangeira, que continua sendo pressuposto para a sua execução. O requerimento para homologação deverá ser formulado pela parte interessada, nos termos do artigo 37 da Lei de Arbitragem, que será realizado por meio de petição inicial, contendo as indicações da lei processual, conforme disposto no artigo 282 do Código de Processo civil.

\footnotetext{
${ }^{37}$ ROZAZ, J. C. Fernández; GARCÍA, Rafael Arenas; ASENSIO, Pedro Alberto de Miguel, In: Derecho de los Negocios internationales, $3^{\mathrm{a}}$ edicíon, Ed. Iustel, Madrid, 2011, p.709. Tradução livre: "O art. 46 da LA/2003 surge para reiterar a definição da sentença estrangeira da LA/1998, isto é, "o pronunciamento fora do território espanhol" soluciona, de uma vez por todas, a questão de dualidade de regimes existentes em nosso ordenamento jurídico e em muitos outros, como consequência da observância da CNY de 1958".

${ }^{38}$ Antes da promulgação da Lei 9.30/96, as sentenças estrangeiras precisavam passar por prévia homologação no tribunal de origem e somente após tal reconhecimento, ela deveria ser trazida para homologação no Brasil, na época realizada pelo STF para assim, adquirir força executiva.

${ }^{39}$ PUCCI, Adriana Noemi, Homologação de Sentenças Estrangeiras In: LEMES, Selma Ferreira, CARMONA, Carlos Alberto, MARTINS Pedro Batista (coordenadores), Arbitragem Estudos em Homenagem ao Prof. Guido Fernando da Silva Soares, In Memoriam; São Paulo:Ed. Atlas S.A., 2007, p.341-342
} 
Os requisitos para o procedimento homologatório estão elencados na Resolução n ${ }^{\text {o }} 9$ de 2005 do próprio STJ e nos artigos 38 e 39 da Lei de Arbitragem. A princípio o procedimento de reconhecimento da sentença estrangeira não tem como objetivo rever o mérito da sentença, mas tão somente verificar o preenchimento de condições formais impostas pelo ordenamento jurídico brasileiro, que comprovem a regularidade e atribuam validade à sentença estrangeira É o que esclarece Nadia de Araujo ${ }^{40}$ :

\begin{abstract}
“A homologação reveste-se de caráter de verdadeira ação, e tem natureza tipicamente jurisdicional. O STF julgava o mérito da ação de homologação ao acolhê-la, o que continua a fazer o STJ. Cria-se situação nova, que passa a produzir efeitos no território nacional.(...) '

$\mathrm{O}$ contraditório se restringe à discussão sobre a satisfação dos requisitos de homologabilidade, considerando julgamento de mérito do pedido. (...) A parte ré não pode pretender discutir a justiça ou injustiça da sentença estrangeira."
\end{abstract}

Os requisitos para homologação de sentença estrangeira encontramse no artigo $5^{\circ}$ da Res. 9/2005 do STJ e no artigo 15 da Lei de Introdução às normas do Direito Brasileiro ${ }^{41}$. São, portanto, requisitos indispensáveis à homologação da sentença estrangeira (I) ter sido proferida por juízo/árbitro competente; (II) a devida citação do réu ou a verificação legal da sua revelia (III) o trânsito em julgado; (IV) atendida as formalidade necessárias para a execução no lugar em que foi proferida; (V) tradução por oficial ou juramentada no Brasil.

Referidos requisitos estão constatados também pelo artigo 38 da Lei $9.307 / 96^{42}$, e mais uma vez a lei fortalece o reconhecimento da autonomia

\footnotetext{
${ }^{40}$ ARAUJO, Nadia de. Direito Internacional Privado: Teoria e Prática Brasileira. 5aed. Rio de Janeiro: Editora Renovar, 2011, p. 329-330.

${ }^{41}$ Nova redação dada pela Lei ${ }^{\circ} 12.376$ de 2010, antes denominada de Lei de introdução ao código civil ("LICC").

${ }^{42}$ Art. 38, L. 9.307/96: Somente poderá ser negada a homologação para o reconhecimento ou execução de sentença arbitral estrangeira, quando o réu demonstrar que:

I - as partes na convenção de arbitragem eram incapazes;

II - a convenção de arbitragem não era válida segundo a lei à qual as partes a submeteram, ou, na falta de indicação, em virtude da lei do país onde a sentença arbitral foi proferida;

III - não foi notificado da designação do árbitro ou do procedimento de arbitragem, ou tenha sido violado o princípio do contraditório, impossibilitando a ampla defesa;

IV - a sentença arbitral foi proferida fora dos limites da convenção de arbitragem, e não foi possível separar a parte excedente daquela submetida à arbitragem;
} 
da cláusula compromissória, garantindo a ela a dedicação de uma lei específica para governar sua existência, validade e eficácia, conforme se confere do inciso II do art. $38^{43}$.

A Res. n. 9/2005 do STJ também aponta os requisitos formais a serem cumpridos para que uma sentença estrangeira seja homologada pelo STJ, sendo certo que as hipóteses para a não homologação estão sempre restritas ao não cumprimento de um destes. Nesse sentido, o próprio corpo normativo restringe as chances de uma sentença não ser reconhecida no país.

É preciso, em conclusão, fazer uma pequena ressalva para o cabimento de recursos da decisão que deferir ou indeferir sentença arbitral estrangeira. Apesar da forte tendência em reconhecer-se as sentenças arbitrais estrangeiras, a possibilidade de se interpor recurso, em especial, o recurso extraordinário, infelizmente, apresentar-se como um obstáculo no quesito celeridade, tão presente na arbitragem. O recurso extraordinário traz consigo outros recursos cabíveis já no Supremo Tribunal Federal o que pode postergar consideravelmente a homologação de uma sentença estrangeira. Por exemplo, o caso a ser analisado na parte II já esta em fase de recurso extraordinário pendente de juízo de admissibilidade, ou seja, ainda é possível haver mudanças na decisão proferida pela Corte Especial.

V - a instituição da arbitragem não está de acordo com o compromisso arbitral ou cláusula compromissória;

VI - a sentença arbitral não se tenha, ainda, tornado obrigatória para as partes, tenha sido anulada, ou, ainda, tenha sido suspensa por órgão judicial do país onde a sentença arbitral for prolatada.

${ }^{43}$ MARTINS, Pedro A. Batista. Apontamentos sobre a lei de arbitragem. Rio de Janeiro: $1^{\text {a ed. Rio }}$ de Janeiro: Ed. Forense, 2008, p. 383 
"The life of the law has not been logic; it has been experience". Oliver Wendell Holmes

\section{Parte II - Análise dos Casos Concretos}

Realizada uma abordagem mais teórica sobre o tema na Parte I, nesta segunda parte buscaremos analisar o acórdão do Superior Tribunal de Justiça, publicado no dia $1^{\circ}$ de Fevereiro de 2012, que homologou parcialmente a sentença estrangeira contestada $\mathrm{n}^{\circ}$. 1, proferida pelo Tribunal Arbitral. Esta segunda parte será dividida em duas outras partes principais: (2.1) Relato dos fatos (2.2) Comentários acerca do caso.

A análise a ser realizada permitirá uma visão prática do entendimento atual do nosso Superior Tribunal de Justiça no que se refere ao reconhecimento da cláusula compromissória e, consequentemente, ao reconhecimento da própria arbitragem como método de solução disputas.

Válido informar que, dada a recente decisão que, rejeitou os Embargos de declaração e manteve a homologação da sentença estrangeira, somente foi publicada em 09 de agosto do presente ano, há ainda Recurso Extraordinário pendente apreciação do juízo de admissibilidade. Portanto, não está descartada a possibilidade do acórdão sofrer eventual reforma após a apresentação do presente trabalho de monografia.

\section{Sentença Estrangeira Contestada № 1 - KR (2007/0156979-5) do Superior Tribunal de Justica. ${ }^{44}$}

\subsection{Relato dos fatos:}

\footnotetext{
${ }^{44}$ STJ, SEC nº1, Rel. Min. Maria Thereza de Assis Moura, Presidente da Sessão Min. Ari Pargendler; dje em: 01.02.2012; Requerente: Kia Motors Corporation; Requeridos: Washington Armênio Lopes; Chong Jin Jeon; Roberto Uchôa Neto; Ásia Motors Do Brasil S/A; Set Participações eEmpreendimentos S/A; Set Trading S/A ; JBP do Brasil; American Samoa Corporation
} 


\begin{abstract}
EMENTA
"SENTENÇA ARBITRAL ESTRANGEIRA CONTESTADA. PRETENSÃO HOMOLOGATÓRIA A SER DEFERIDA EM PARTE. REQUISITOS DA LEI ATENDIDOS. VÍCIOS DE NEGAÇÃO INEXISTENTES. AMPLA COMPETENCIA PARA DIRIMIR CONFLITOS ENTRE OS CONTRATANTES DE JOINT VENTURE

Sendo lícito o negócio jurídico realizado no Brasil, por partes de legítimo contrato de joint venture, não se the pode extrair as consequências jurídicas da quebra do acordado. Por mais razão, não se pode afastar a convenção arbitral nele instituída por meio de cláusula compromissória ampla, em que se regulou o Juízo competente para resolver todas as controvérsias das partes, incluindo aí a extensão dos temas debatidos, sob a alegação de renúncia tácita ou de suposta substituição do avençado.

Uma vez expressada a vontade de estatuir, em contrato, cláusula compromissória ampla, a sua destituição deve vir através de igual declaração expressa das partes, não servindo, para tanto, mera alusão a atos ou a acordos que não tinham o condão de afastar a convenção das partes.

Ademais, o próprio sentido do contrato de joint venture assinado pelas partes elimina o argumento de que uma delas quis abdicar da instituição de juízo arbitral no estrangeiro.

A revelia não importa em falta de citação, mas, ao contrário, a pressupõe.

O laudo arbitral lavrado por Corte previamente prevista na cláusula compromissória obedece aos requisitos para sua internalização em território pátrio, máxime porque não ofende os ditames dos arts. $3^{\circ}, 5^{\circ}$ e $6^{\circ}$ da Resolução $n .{ }^{\circ} 9$ desta Corte, devendo, por isso, ser homologado.

Havendo a Justiça brasileira, definitivamente, resolvido controvérsia quanto a um dos temas do pedido de homologação da sentença arbitral, deve a pretensão ser negada quanto a isso por obediência à coisa julgada.

Homologação deferida em parte, com a exclusão dos itens 7 e 10 da decisão arbitral."
\end{abstract}

Trata-se de pedido de homologação de sentença arbitral estrangeira proferida pelo Tribunal Arbitral de Nova Iorque, requerido pela Kia Motors Corporation ("Kia"), em substituição à Asia Motors Company (AMC) a qual foi incorporada ${ }^{45}$.

A sentença arbitral teve por objeto o contrato de parceria, denominado joint venture, celebrado entre as partes em junho de 1997, visando expandir as vendas de veículos da AMC na América Latina. No contrato estava previsto convenção arbitral e cláusula compromissória, conforme se infere da cláusula 14.3 e seguintes:

"14.3 Qualquer conflito ou reclamação que surja deste Acordo, ou que a ele se relacione, incluindo a interpretação, aplicação e rescisão deste Acordo, e que não possa ser resolvido amigavelmente entre as partes, será resolvido por arbitragem compulsória, em conformidade com as

45 Alguns trechos do "relato dos fatos" foram retirados do voto da relatora Ministra Maria Thereza de Assis Moura bem como do voto-vista da Ministra Nancy Andrighi e do Ministro Massami uyeda. 
Regras de Conciliação e Arbitragem da Câmara Internacional do Comércio ( "ICC"). (...)"

Durante a vigência do negócio jurídico, ocorrem problemas de entendimento entre as partes que levaram à realização de assembleia geral extraordinária pela Ásia Motors Brasil (AMB) - empresa constituída para viabilizar a parceria-, em março de 1998, na qual houve aprovação de aumento de capital a ser imposto aos acionistas, em especial à Kia.

Em contrapartida, em janeiro de 2000, a Kia ajuizou medida cautelar perante uma das varas cíveis da comarca de Salvador/Bahia a fim de suspender os efeitos das deliberações decorrentes da assembleia geral extraordinária. Em tempo, apresentou ação principal, de rito ordinário, para anular a assembleia.

Tanto na Cautelar como na Ação Principal, a Kia ressalvou expressamente que ao submeter-se à justiça brasileira não estava renunciando à cláusula arbitral, informando que a via judicial estava sendo adotada em razão da urgência das medidas e como única alternativa para assegurar os seus direitos, tendo em vista que o tribunal arbitral competente ainda não havia sido constituído e a tutela de urgência não poderia aguardar pela sua constituição.

Logo após o ajuizamento destas ações perante a justiça estatal, fundada em cláusula compromissória específica, suscitando violação ao contrato de joint venture, e pedido de indenização, a Kia formulou pedido de procedimento arbitral junto à Câmara Comércio Internacional.

A sentença arbitral entendeu pela violação da $\mathrm{AMB}$ ao contrato de joint venture, o que resultou na recisão do mesmo, reconhecendo o aumento de capital da AMB como fraudulento e condenando todos os requeridos ao pagamento de indenização por perdas e danos à AMC, hoje Kia. Prolatada a sentença, a Kia entrou com um pedido de homologação de sentença arbitral estrangeira perante o Superior Tribunal de Justiça. 
Em sede de contestação, e como tese principal, um dos Requeridos (Washington Armênio Lopes) alegou os seguintes pontos, transcritos do voto da Relatora Ministra Maria Thereza de Assis Moura:

De forma resumida, são os temas da contestação desse Requerido:

a) incompetência do Tribunal Arbitral em face de três circunstâncias:

$1^{\text {a) }) ~ s u p e r a c ̧ a ̃ o ~ d a ~ c l a ́ u s u l a ~ c o m p r o m i s s o ́ r i a, ~ i n s t i t u i ́ d a ~ n o ~ c o n t r a t o ~ d e ~ j o i n t ~}$ venture, por deliberações posteriores, notadamente o acordo de acionistas e o contrato social, que, assinados logo depois do contrato inicial, não previram a convenção arbitral;

$\left.2^{\mathrm{a}}\right)$ o contexto da lide ajuizada no Tribunal Arbitral estava fora da convenção arbitral, na medida em que a cláusula compromissória somente abarcava as controvérsias que se relacionassem ao exercício dos direitos dos acionistas tratados no Capítulo 4 do contrato respectivo, que cuidava acerca unicamente da opção de compra e venda de ações.

$3^{\mathrm{a}}$ ) revogação tácita da convenção arbitral pela vontade das partes ao se submeterem à competência da Justiça brasileira, em ação cautelar e em ação de conhecimento, controvérsia acerca de deliberações assembleares tomadas em 2/3/1998. O Requerido sustenta, in casu, a hipótese de renúncia à cláusula compromissória por parte da Requerente, autora dos procedimentos judiciais.

b) Falta de citação das empresas American Samoa Corporation e Bambari International S/A no processo de arbitragem.

No que concerne o item b), sobre o não cumprimento do artigo $5^{\circ}$, II, da Res. n. 9/2005 do STJ em razão da falta de citação de duas das demais requeridas, as empresas American Samoa e Bambari, a corte entendeu que as empresas foram citadas, porém optaram por não participar do procedimento, e assim, se deram por revéis. Dessa forma, a verificação de revelia rechaçou a hipótese de falta de citação.

Já sobre as circunstâncias do item a), o Superior Tribunal de Justiça entendeu da seguinte maneira:

$1^{a}$ Preservou-se o princípio da autonomia da vontade das partes, posto que estas firmaram livremente acordo com cláusula compromissória, submetendo-as ao juízo arbitral. Ainda, a renúncia à cláusula compromissória é interpretada de maneira restritiva e, portanto, exige-se que esta seja feita expressamente; 
$2^{\mathrm{a}}$ ) Consagrou a autonomia da cláusula compromissória em relação ao contrato principal e entendeu o contrato de joint venture como aquele contrato-mãe, que deu origem a todas demais deliberações. Assim, a cláusula compromissória não teria sido renunciada, mas sim aplicada a todos as futuras controvérsias.

3) O mero ajuizamento de ação cautelar, e da seguida ação ordinária, não implica na renuncia à cláusula compromissória, uma vez que a urgência da questão exige medida cautelares, inclusive prevista no próprio ordenamento jurídico brasileiro, disposto no artigo 22 da lei 9.307/96 e nos $\S \S 3^{\circ}$ e $3^{\circ}$ do artigo $4^{\circ}$ da Res. $n^{\circ}$ 9/2005 do STJ.

O pedido de homologação foi deferido em parte tendo em vista a existência de decisão do juízo nacional já transitada em julgado, que caso se considerasse os itens já decididos pela Justiça Brasileira estariam violando a soberania nacional, pois prevaleceria uma sentença estrangeira sobre a decisão judicial brasileira já transitada em julgado, conforme aludido pelo Ministro Francisco Falcão. Assim sendo, afastaram-se da homologação os itens e 10 da sentença arbitral que versam sobre a nulidade da assembleia geral extraordinária já deferida pela decisão judicial. Condenou-se os Requeridos em custas e honorários em $\mathrm{R} \$ 2.000,00$. 


\subsection{Comentários ao caso}

Expostos os fatos do caso em questão, atentaremos para as suas particularidades, objetivando um aprofundamento das alegações apresentadas por um dos requeridos em sede de contestação e os fundamentos utilizados para rechaça-las, que foram os pontos destrinchados no voto da Relatora Ministra Maria Thereza. As três circunstâncias que evidenciariam uma suposta incompetência do tribunal arbitral de Nova Iorque serão divididas em três tópicos diferentes, para assim abordarmos de maneira mais detalhada os fundamentos usados pelo Superior Tribunal de Justiça no caso concreto.

\section{a) Superação da cláusula compromissória pelas deliberações posteriores ao Contrato de Joint Venture.}

\section{a.1) Prevalência do acordo de base nas Joint Ventures}

Existem determinadas operações internacionais que exigem o estabelecimento de mecanismos de cooperação entre empresas que não implicam nem na constituição de um grupo multinacional, ou tampouco na fusão das empresas participantes. Aqui, há a manutenção de independência econômica das empresas-partes no negócio jurídico.

Como uma resposta à dinâmica empresarial contemporânea, a joint venture é uma maneira, dentre outras, das empresas firmarem uma parceria, orientada na execução de um projeto comum, visando uma cooperação para adquirirem força no mercado ${ }^{46}$.

A joint venture tem suas raízes no direito anglo-saxão. As práticas empresarias norte-americanas ensejaram decisões dos tribunais que,

\footnotetext{
${ }^{46}$ LAMY FILHO, Alfredo e PEDREIRA, José Luiz Bulhões. A Lei das S.A.: pressupostos,

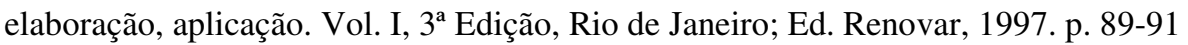


começaram a esboçar os contratos de joint venture, identificando as características típicas deste instituto ${ }^{47}$.

$\mathrm{O}$ dicionário jurídico Black $^{48}$ usa a seguinte definição para joint venture:

"A commercial or maritime enterprise undertaken by several persons jointly, a limited partnership, not limited in the statutory sense as to the liability of the partners, but as to its scope and duration."

O Contrato de Joint Venture faz uso do acordo de base, contrato guarda-chuva, ou "acordo moldura". Esse instrumento jurídico possui tal denominação, pois dele acrescentam-se outros contratos subsidiários, ou "acordos satélites", que são elaborados a partir das determinações ajustadas no contrato originário. Ou seja, todos aqueles acordos firmados após o acordo de base, o acompanharão.

Nesse contexto, o professor Luiz Olavo Batista ${ }^{49}$ descreve:

"Os contratos de joint venture são criados a partir de um acordo-base em torno do qual gravitam os contratos satélites, sendo seus objetivos realizados por um órgão de gestão e controle que pode ser uma pessoa física ou jurídica, mandatária, formal como uma sociedade por ações, ou informal, como o gerente de um consórcio."

Sobre o instrumento jurídico base desse contrato, Alfredo Lamy Filho e José Luiz Bulhões Pedreira ${ }^{50}$ esclarecem:

"O acordo de base - já diz sua designação - é a chave da "joint venture". Como observam L.O.Batista e P. Durand-Barthy (1986, p.49) - esse acordo é que contém "a verdade" das relações contratadas, por oposição aos acordos satélites, mais formais adaptados aos modelos concebidos para situações gerais."

${ }^{47}$ VALÉRIO, Marco Aurélio Gumieri. Cláusula Compromissória nos contratos de” Joint Venture". In: Revista de Direito Mercantil - vol. 130, São Paulo, Edi. Malheiros, abr.-Jun./2003. p. $151-152$

${ }^{48}$ Black's Law Dictionary, 9th edition, Chief editor Bryan A Garner, West - a thomson business, 2004, p.915 - Tradução livre: Uma empresa comercial ou marítima assumida por pessoas em conjunto, uma sociedade limitada, não limitada no sentido legal de responsabilidade dos sócios, mas sim no do seu fim e duração.

${ }^{49}$ BAPTISTA, Luiz Olavo. A joint venture: Uma perspectiva comparatista, Revista de Direito Mercantil 42/39, Abr.-Jun. de 1981.

${ }^{50}$ LAMY FILHO, Alfredo e PEDREIRA, José Luiz Bulhões. A Lei das S.A. (pareceres), Vol. II, $3^{\text {a }}$ Edição, Rio de Janeiro; Ed. Renovar, 1997. p. 183-185 
E eles procedem, abordando, especificamente, a cláusula arbitral:

\begin{abstract}
"Realmente, esse acordo de base é a própria "joint venture"(...) Nele inserem-se todas as estipulações que vão governar a vida do empreendimento (...) a duração do contrato, e o direito de retirada, o regulamento dos conflitos e divergências, como a arbitragem, a política de distribuição de lucros e contratações etc."
\end{abstract}

Nesse sentido, a joint venture está fincada no acordo de base, que regerá todo o seu funcionamento, todas as suas condições gerais. Assim, todos os demais contratos, como por exemplo o acordo de acionistas ou um fornecimento de tecnologia -como no caso em questão-, serão elaborados de modo a amoldarem-se ao acordo de base.

A própria interpretação desses acordos satélites depende daquilo disposto no acordo-base, tendo em vista que este é muito mais amplo que aquele, abrangendo, mesmo que de maneira mais genérica, toda e qualquer circunstância que venha a surgir. Não existe, portanto, a possibilidade de um acordo satélite contradizer ou revogar o acordo originário.

Entendimento diverso possui Carmona. Especificamente no caso em análise, houve entendimento diverso na doutrina. Em consulta solicitada por um dos requerentes, a Ásia Motors Brasil ao Carmona ${ }^{51}$, em seu parecer, entendeu que o Estatuto e o Acordo de Acionistas, firmados no mesmo dia em que o contrato de joint venture, modificaram o combinado original, e assim o desconsideraram.

\title{
Confere-se:
}

“(...) tal modelo pressupõe seja celebrado um contrato prévio (joint venture, que prevalecerá até que seja criada a sociedade) e um contrato subsequente, que tomará o lugar daquele anterior. Não foi isso, porém, o que aconteceu no caso concreto, onde os contratos que deveriam ter sido subsequentes (o Estatuto e o Acordo de Acionistas) foram firmados junto

\footnotetext{
${ }^{51}$ CARMONA, Carlos Alberto, Contrato de Joint Venture. Contratos-satélites que absorvem as previsões constantes do contrato-base. Revogação tácita e revogação expressa de cláusula compromissória. Manifestação de vontade no sentindo de restringir os limites da cláusula compromissória. Autonomia da vontade das partes. Impossibilidade de homologar sentença arbitral estrangeira. Art. 38, II, da lei de arbitragem In: Revista de Arbitragem e Mediação, vol.19 Out-Dez/2008. p. 153
} 
com o contrato de joint venture (ou seja, na mesma data). A consequência é clara: o Estatuto e o Acordo de Acionistas passaram a reger por inteiro as relações entre as partes."

Entretanto, em linhas opostas se deu o entendimento do STJ, reconhecendo que diante da complexidade e relevância do negócio jurídico, não havia sentido em as partes estipularem no contrato-mãe uma cláusula compromissória cheia, garantindo ampla competência ao Tribunal Arbitral e na mesma data revogarem tal cláusula sem referência expressa.

Para a Corte especial, o acordo de base era a "célula mãe" dos demais, que regulava a relação das partes contratantes de acordo com os termos e condições determinadas no acordo de base. Além disso, como a Joint Venture, o acordo de acionistas e estatuto social foram firmados no mesmo dia, não havia razão para inserir a mesma cláusula arbitral em todos os outros documentos, sendo assim a mera ausência de previsão da cláusula não implicaria na renúncia das partes em submeterem as futuras controvérsias ao juízo arbitral.

\section{a.2) Autonomia da Cláusula Compromissória}

Não obstante o entendimento do STJ sobre a prevalência do acordo de base sobre os acordos satélites, a Corte discorreu ainda sobre a autonomia da cláusula compromissória tendo em vista que, mesmo que os demais acordos tivessem, de alguma maneira, dado ensejo à revogação do acordo-matriz, esta revogação não implicaria necessariamente na nulidade da cláusula compromissória.

Como exposto na Parte I do presente trabalho, a cláusula compromissória goza de autonomia em relação ao contrato em que está inserida. $\mathrm{O}$ artigo $8^{\circ}$ da Lei de Arbitragem garantiu a possibilidade de um contrato ser nulo, sem que a cláusula arbitral nele contida seja, igualmente, considerada nula. 
Nessa linha de raciocino, ilustra Jacob Dolinger ${ }^{52}$ :

"A expressão "autonomia da cláusula compromissória" possui dois significados: 1) que sua validade e eficácia não dependam da validade ou eficácia de um outro contrato em que esteja inserida ou ao qual se refira, de tal modo que não há de se falar em relação de acessoriedade entre aquela e este; 2) que sua validade e eficácia não são, necessariamente, determinadas pela lei aplicável a este contrato em que esteja inserida ou ao qual se refira."

Mencionado princípio vem sendo, há anos, alvo de debate de diversos países que, em regra, vem decidindo pelo reconhecimento da autonomia da cláusula compromissória, conforme se confere da decisão do Tribunal Arbitral do caso Companhia Nacional Iraniana de Petróleo (NIOC) vs. Elf. Aquitaine ${ }^{53}$ :

The autonomy of an arbitration clause is a principle or international law that has been consistently applied in decisions rendered in international arbitration, in the writings of the most qualified publicists on international arbitration, in arbitration regulations adopted by international organizations and in treaties. Also, in many countries, the principle forms part of national arbitration law.

Assim, o tribunal entendeu que a cláusula arbitral conserva-se válida, mesmo na hipótese de arguição de nulidade do contrato, por uma das partes, no caso a NIOC.

No segundo sentido da autonomia da cláusula compromissória, a doutrina internacional também tem reconhecido que a lei aplicável à cláusula pode ser distinta daquela do contrato no qual se insere, conforme retira-se do exposto por Rachel Engle ${ }^{54}$ :

${ }^{52}$ DOLINGER, Jacob; TIBÚRCIO, Carmen. Direito Internacional Privado parte especial: Arbitragem Comercial Internacional. Rio de Janeiro: Ed. Renovar, 2003, p. 173

${ }^{53}$ BORN, Gary B. International Commercial Arbitration.Vol. I. Kluwer Law International, 2009. p. 345. Tradução livre: A autonomia da cláusula compromissória é um princípio ou direito internacional que tem sido constantemente aplicado em decisões proferidas em arbitragem internacional, e adotados pela doutrina na area da arbitragem internacional, e pelos regulamentos de arbitragem das organizações e tratados internacionais. Além disso, em muitos países,o princípio faz parte da lei de arbitragem nacional.

${ }^{54}$ ENGLE, Rachel, Comments: Party Autonomy in International Arbitration: Where Uniformity Gives Way to Predictability. Transnat'l Law, 2002. p. 330. Tradução livre: A lei aplicável à própria convenção de arbitragem pode ser distinta da lei aplicável ao contrato no qual se insere, como 
"The Law applicable to the arbitration agreement itself is distinguishable from the Law applicable to the underlying contract, as described above. (...) For example, if a party challenges the validity of the underlying contract, the party is not necessarily challenging the validity of the arbitration agreement; ordinarily, the dispute may remain subject to arbitration."

A jurisprudência nacional também já se manifestou anteriormente sobre o assunto. Cite-se ementa da Apelação n. 9134925962008826, julgada em 29/06/2011, pela 30 Câmara de Direito Privado do Tribunal de Justiça de São Paulo (TJSP):

\begin{abstract}
ARBITRAGEM - AÇÃO DE CUMPRIMENTO DE OBRIGAÇÃO DE FAZER - EXECUÇÃO ESPECÍFICA DE CLÁUSULA ARBITRAL ART. T DA LEI N. 9.307/96 - RESISTÊNCIA DA OUTRA PARTE CONTRATANTE À INSTITUIÇÃO DA ARBITRAGEM, PREVISTA NO CONTRATO COMO MODO ALTERNATIVO DE SOLUÇÃO DOS LITÍGIOS DECORRENTES DA RELAÇÃO CONTRATUAL INEXISTÊNCIA DE CONEXÃO COM AÇÃO ANULATÓRIA DOS CONTRATOS FIRMADOS ENTRE AS PARTES - PEDIDOS E CAUSAS DE PEDIR DIVERSOS - QUESTÃO DA VALIDADE DO NEGÓCIO SUBJACENTE QUE NÃO SE REVELA PREJUDICIAL À EXECUÇÃO DA CLÁUSULA COMPROMISSÓRIA AUTONOMIA DA CLÁUSULA COMPROMISSÓRIA ESTABELECIDA NO ART. 80 DA LEI N. 9.306/97-JUÍZO A QUO COMPETENTE PARA APRECIAÇÃO DA MATÉRIA PROCEDIMENTO JUDICIAL DO ART. 7o DEVIDAMENTE OBSERVADO - PARTE RÉ CITADA PARA A AUDIÊNCIA, COM OFERECIMENTO DE OPOSIÇÃO À INSTALAÇÃO DA ARBITRAGEM - EVENTUAIS VÍCIOS DE NULIDADE SANADOS COM O OFERECIMENTO DA RESPOSTA EM AUDIÊNCIA INEXISTÊNCIA DE PREJUÍZO A ENSEJAR A ALEGADA NULIDADE DO PROCESSO JUDICIAL - IMPROCEDÊNCIA DA RESISTÊNCIA À INSTITUIÇÃO DA ARBITRAGEM,INCLUSIVE JÁ ULTIMADA - SENTENÇA CONFIRMADA. (grifo nosso)
\end{abstract}

Nesse mesmo sentido, percebe-se que a decisão do STJ no caso em análise reforça o entendimento que vem sendo construídos pelos nossos tribunais.

descrito acima. (...) Por exemplo, se uma parte contestar a validade do contrato, não necessariamente, contesta-se a validade da convenção de arbitragem e, sendo assim, a disputa pode manter-se sujeita à arbitragem. 


\section{b) As controvérsias levadas à apreciação do tribunal não estavam abrangidas pela Convenção arbitral.}

O ponto "a" abordou especificamente a natureza jurídica do contrato de joint venture. Contudo, toda a fundamentação - Autonomia da vontade das partes e o princípio da boa-fé - abordada no voto Relator, que será destrinchada no ponto "b" também serviu para refutar a alegação do ponto "a". Ou seja, pontos a e b foram enfrentados pelos mesmos argumentos do STJ.

\section{b.1) Autonomia da vontade das partes}

Deve-se ter em mente que o contrato se origina da declaração de vontade das partes contratantes. Um negócio jurídico inicia com a manifestação de vontade de uma pessoa (física ou jurídica) capaz. O princípio da autonomia da vontade é a base para se realizar um acordo.

Nas lições de Caio Mario ${ }^{55}$, o princípio da autonomia da vontade é exercido pelas partes em momentos essenciais da existência dos acordos: (i) a faculdade que possuem de contratar ou de não contratar; (ii) a liberdade para escolher com quem contratar e o tipo de negócio a ser celebrado; (iii) a liberdade para determinar o conteúdo do contrato; e (iv) liberdade para obrigar o cumprimento do objeto acordado.

Sobre a liberdade de contratar especificamente no Direito Societário,explana Marcelo D. G. Vilela ${ }^{56}$ :

"No âmbito do direito societário, pode-se afirmar que quase a totalidade das questões enquadra-se no campo da arbitrabilidade, sobretudo porque a sociedade, seja simples ou empresária, observada do ponto de vista do encontro de vontades de seus associados no momento de sua criação

\footnotetext{
55 PEREIRA, Caio Mário da Silva. Instituições de Direito Civil - Contratos. Vol. III, $13^{\text {a }}$ edição. Rio de Janeiro: Ed. Forense, 2009. p. 19-20

${ }^{56}$ VILELA, Marcelo Dias Gonçalves, Arbitragem no Direito Societário; Belo Horizonte: Ed. Mandamentos, 2004. p. 169
} 
decorre dos princípios da liberdade de contratar e da livre iniciativa da atividade econômica, consagrados na Constituição da República de 1988 .

A arbitragem, por sua vez, decorre fundamentalmente da vontade das partes, que possuem total liberdade para elegê-la ou não. A doutrina brasileira, a partir da ideia da professora Selma Lemes, ${ }^{57}$ vem entendendo que a arbitragem repousa no princípio da autonomia da vontade, que surge como meio de solução de conflitos, quando as partes assim estipulam contratualmente.

In caso, a cláusula arbitral estava inserida expressamente no Acordo de base, o que evidenciou a vontade das partes em optarem pela Arbitragem como método de resolução dos conflitos. O STJ concluiu que a arbitragem é uma manifestação de vontade das partes, confirmado por meio da cláusula compromissória e a partir do momento em que esta foi expressamente inserida no acordo de base, a invalidade da cláusula compromissória comprometeria o reconhecimento da autonomia da vontade das partes.

É possível ver o entendimento do STJ em outros julgados da própria corte, cite-se parte do voto Relator da SEC n. $885^{58}$ :

Sendo a convenção de arbitragem fonte ordinária processual arbitral, destinada a por fim aos conflitos de interesses, tanto entre nacionais como entre contratos internacionais, esta tem, obrigatoriamente, fundamento na autonomia de vontade das partes, onde as partes optam espontaneamente em submeter os litígios existentes ou futuros à decisão de um árbitro, dispensando a jurisdição estatal. (grifo nosso)

Importante notar que, no caso em análise, o princípio da autonomia da vontade foi mencionado tão somente no que se refere à liberdade das partes em optarem pela via arbitral como solução dos seus conflitos, e não, no que tange sobre a liberdade no procedimento arbitral.

\footnotetext{
${ }^{57}$ LEMES, Selma, Cláusulas arbitrais ambíguas ou contraditórias e a interpretação da vontade das partes. In: MARTINS, Pedro Batista; GARCEZ, José M. Rossani. Reflexões sobre Arbitragem in Memoriam do Desembargador Cláudio Vianna de Lima. São Paulo: Ed.Ltr, 2002, p. 188.

${ }^{58}$ STJ, SEC 885 EX 2005/0034898-7, CE, Rel. Min. Francisco Falcão, julgamento em 18/04/2012.
} 


\section{b.2) Princípio da boa-fé objetiva}

Em conjunto com o principio da autonomia das partes, o princípio da boa-fé, positivado pelo código civil de 2002 em seus artigos $113^{59}$ e $422^{60}$, que desde então norteia as relações contratuais, foi também usado pela Corte para firmar seu entendimento. Assim, no surgimento do litígio, apoiando-se no princípio da boa-fé, entendeu a Corte que as partes não poderiam atuar de forma diversa daquela formalmente pactuada, devendo se esforçar ao máximo para cumprir a integralidade do contrato conforme previsto.

O conceito do princípio da boa-fé tem sua origem no "bona fides" do Direto Romano. No comércio internacional, busca-se a disseminação desse princípio através da construção de uma jurisprudência internacional, bem como a criação de conceitos atribuídos pela lex mercatoria. Como exemplo, podemos citar os princípios do UNIDROIT relativos aos contratos internacionais, os quais auxiliam no conceito do princípio da boa-fé como regra para interpretação da real intenção das partes contratantes.

Nessa esteira, está o conceito trazido pelo professor Fouchard ${ }^{61}$ :

"From this broad rules that contracts must be interpreted in good faith, more specific rules of interpretation can be derived, all of which stem from the need to establish the actual intention of the parties. (...). Second, the attitude of the parties after the signature of the contract and up until when the dispute arose should be taken into account, as that attitude will indicate how the parties themselves actually perceived the agreements in dispute. This rule is sometimes referred to as "practical and quasiauthentic interpretation", or "contemporary practical interpretation" and is commonly applied in arbitral case law. In particular, recognition of the existence of an arbitration agreement will often result from a party initially relying on the existence of that agreement to avoid the

\footnotetext{
${ }^{59}$ Art. 113, L. 10.406/02: "Os negócios jurídicos devem ser interpretados conforme a boa-fé e os usos do lugar de sua celebração."

${ }^{60}$ Art. 422, L.10.406/2002: "Os contratantes são obrigados a guardar, assim na conclusão do contrato, como em sua execução, os princípios de probidade e boa-fé."

${ }^{61}$ FOUCHARD, Philippe; GAILLARD, Emmanuel; GOLDMAN, Berthold. On International Commercial Arbitration, org. (Gaillard, Emmanuel, \& Savage, John); Kluwer Law International: Haia, 1999, p. 257-258
} 
jurisdiction of the courts, but subsequently denying its existence or validity before an arbitral tribunal."

Fouchard ilustra o que entende por observância da boa-fé exatamente com o caso das partes que pactuam pela convenção de arbitragem, mas posteriormente negam sua existência ou validade perante um tribunal arbitral. No caso em tela, a cláusula compromissória prevista era a cláusula cheia, ou seja, já trazia todos os elementos suficientes para que a arbitragem fosse iniciada por qualquer uma das partes sem qualquer resistência, e ainda, abrangia de maneira extensa a competência do juízo arbitral, pois, determinava que para "qualquer conflito ou reclamação", que surgisse do acordo ou que a ele estivesse relacionado seria resolvido por arbitragem compulsória.

\section{c) Revogação tácita da cláusula compromissória em razão da controvérsia ter sido submetida à justiça brasileira.}

A terceira alegação feita por um dos requeridos em sede de contestação no caso concreto em análise foi a suposta renuncia à convenção arbitral pela AMC, que teria ocorrido ao submeter o objeto do caso à competência da justiça brasileira em ação cautelar e ação de conhecimento.

\section{c.1) Das medidas cautelares pré-arbitrais.}

Como explicitado na parte I, o instituto da arbitragem tem como uma de suas principais vantagens a celeridade, hoje indispensável nas relações comerciais. Quando a convenção arbitral é inserida em um contrato, as partes estão buscando, essencialmente, uma solução célere e segura para os eventuais litígios surgidos da relação contratual.

Entretanto, mesmo gozando de tal vantagem, em regra, um tempo imprevisível é despendido para que o juízo arbitral seja instaurado. A teor do artigo 19 da lei 9.307/96, o procedimento arbitral é instituído após a 
aceitação da nomeação pelo árbitro, se for único, ou por todos, se forem vários, enquanto que o Regulamento da CCI, em seu artigo 4.2, explicita que a arbitragem tem inicio com a propositura da ação perante a corte. Sem entrar nos inúmeros entendimentos da doutrina nacional e internacional sobre o inicio da instauração da arbitragem, inegável é que ocorrerá um lapso temporal considerável entre a propositura da arbitragem e a sua instituição ${ }^{62}$.

Ocorre que, em situações de urgência, em estão presentes o Fumus Boni luris e o Periculum in mora, e que se não resguardadas podem gerar danos irreparáveis. Nesses casos, o fator tempo será determinante para não deixar o direito perecer.

Para a professora da Universidade de São Paulo, Selma M. F. Lemes, ao acordarem pela cláusula de arbitragem, as partes não estão afastando a possibilidade de uma delas buscar uma tutela de urgência perante o judiciário, visto que as instâncias judicial e arbitral não são excludentes, mas coexistem em harmonia ${ }^{63}$. Assim, se não há tribunal arbitral constituído, e existe uma situação de urgência, - evidenciada pela possibilidade do perecimento do direito face ao transcurso do tempo -, o meio mais recomendado para a sua preservação vem a ser justamente a adoção de medidas cautelares assecuratórias em sede judicial.

Nesse sentido, enquanto não instaurada a Arbitragem, não existe juízo arbitral para dirimir sobre a medida cautelar e, portanto, esta será de competência do juízo estatal ${ }^{64}$.

É Conveniente ressaltar que em âmbito internacional, A Lei-Modelo da UNCITRAL sobre a Arbitragem Comercial Internacional, dispôs em seu

\footnotetext{
62 ARMELIN, Donald. Tutela de urgência e arbitragem.In: Tutelas de Urgência e Cautelares Estudos em homenagem a Ovídio A. Baptista da Silva. ARMELIN, Donald (coord.), Rio de Janeiro: Ed. Saraiva, 201. P.363

${ }^{63}$ LEMES, Selma Maria Ferreira. Parecer: Medidas Cautelares prévias à instauração da arbitragem. - Análise à luz do artigo 19 da Lei de Arbitragem (instituição da arbitragem).p. 16 Disponível em:<< http://www.selmalemes.com.br/artigos/artigo_juri29.pdf $>>$

64 BENETI, Sidinei. Arbitragem e tutelas de urgência. In: Revista do Advogado Ano XXVI, N ${ }^{\circ}$ 8, Set. 2006. p.103
} 
artigo $9^{\circ 65}$ que, em caso de urgência, as partes possuem a liberdade de recorrerem ao judiciário para obterem uma medida cautelar, sem que este ato contrarie a convenção de arbitragem:

"Article 9. Arbitration agreement and interim measures by court:

It is not incompatible with an arbitration agreement for a party to request, before or during arbitral proceedings, from a court an interim measure of protection and for a court to grant such measure."

Entende-se do dispositivo transcrito acima que, em caso de urgência, as partes possuem a liberdade de recorrerem ao judiciário para obterem uma medida cautelar, sem que este ato contrarie a convenção de arbitragem.

Além do artigo 26 conferir poderes ao tribunal arbitral para tomar medidas provisórias consideradas necessárias quando solicitado pelas partes, no que se refere às medidas cautelares pré-arbitragem, dispõe no item $26.9^{66}$ :

"26.9. A request for interim measures addressed by any party to a judicial authority shall not be deemed incompatible with the agreement to arbitrate, or as a waiver of that agreement."

Já a CCI possui desde 1990 um regulamento de procedimento cautelar pré-arbitral, denominado corretamente de Réglement de référé préarbiral, que serve como um mecanismo para assegurar o provimento de tutelas de urgência. Pelos dispositivos do regulamento, as partes contratantes podem recorrer a um procedimento cautelar pré-arbitral. Confere-se da definição do item 1.1 do regulamento ${ }^{67}$ :

\footnotetext{
${ }^{65}$ Tradução livre: Não é incompatível com a convenção de arbitragem uma parte requerer medida provisória de proteção a um tribunal, antes ou durante o procedimento arbitral, bem como a concessão dessa medida pelo tribunal

${ }^{66}$ Tradução livre do Artigo 26.9: “A solicitação de medidas provisórias requerida por qualquer das partes à autoridade judicial não será considerada incompatível com a convenção de arbitragem, ou como uma renúncia à convenção."

67 Disponível em: http://iccwbo.org/products-and-services/arbitration-and-adr/pre-arbitralreferee/rules-for-a-pre-arbitral-referee-procedure/

Tradução: "O presente Regulamento estabelece um procedimento denominado "procedimento cautelar pré-arbitral", que prevê a nomeação imediata de uma pessoa ("Terceiro Ordenador"), investida de poderes para ordenar determinadas medidas antes que seja provocado o tribunal arbitral ou estatal competente para decidir o mérito da controvérsia (a "Jurisdição Competente")". Disponível em: http://www.cbar.org.br/PDF/rules_pre_arbitral_portuguese.pdf
} 
(1.1)These Rules concern a procedure called the "Pre-Arbitral Referee Procedure" which provides for the immediate appointment of a person (the "Referee") who has the power to make certain Orders prior to the arbitral tribunal or national court competent to deal with the case (the "Competent Authority") being seized of it.

Apesar dos mais de 20 anos de vigência do mencionado regulamento, e do seu reconhecimento pela Corte Francesa, na prática internacional este tem sido pouco utilizando. Contudo, bem se vê um comportamento da sociedade internacional em prol da criação de regras para superar qualquer obstáculo impeditivo do curso com comércio internacional e garantir a eficácia do juízo arbitral.

No cenário nacional, a Lei $9.307 / 96$, em seu artigo $22 \$ 4^{\circ 68}$ permitiu aos árbitros solicitarem ao juízo estatal a execução de medida cautelar. Contudo, não obstante o dispositivo conferir ao árbitro o poder para requerer ao judiciário a execução de tais medidas, nada impede que, na hipótese de a parte não poder solicitar a medida cautelar ao árbitro, pois o juízo arbitral ainda não foi instaurado -como ocorreu no caso em análise-, valer-se da via judicial, sem que a arbitragem fique prejudicada ${ }^{69}$.

Nesse sentindo, tem caminhado a jurisprudência pátria, que parece reafirmar o entendimento da decisão proferida na SEC $\mathrm{n}^{\mathbf{o}}$; como se extrai do julgamento do REsp 1297974/RJ, ocorrido em junho deste ano:

\section{DIREITO PROCESSUAL CIVIL. ARBITRAGEM. MEDIDA CAUTELAR. COMPETÊNCIA. JUÍZO ARBITRAL NÃO CONSTITUÍDO. \\ 1. O Tribunal Arbitral é competente para processar e julgar pedido cautelar formulado pelas partes, limitando-se, porém, ao deferimento da tutela, estando impedido de dar cumprimento às medidas de natureza coercitiva, as quais, havendo resistência da parte em acolher a determinação do(s) árbitro(s), deverão ser executadas pelo Poder Judiciário, a quem se reserva o poder de imperium. \\ 2. Na pendência da constituição do Tribunal Arbitral, admite-se que a parte se socorra do Poder Judiciário, por intermédio de medida de natureza cautelar, para assegurar o resultado útil da arbitragem.}

\footnotetext{
${ }^{68}$ Art. $22, \S 4^{\circ}$ L. 930/96: "Ressalvado o disposto no $\S 2^{\circ}$, havendo necessidade de medidas coercitivas ou cautelares, os árbitros poderão solicitá-las ao órgão do Poder Judiciário que seria, originariamente, competente para julgar a causa"

${ }^{69}$ CARMONA, Carlos Alberto. Arbitragem e Processo, um comentário à Lei $n^{o}$. 9.307/96. 3a . ed. São Paulo: Ed. Atlas S.A., 2009. p. 327
} 
3. Superadas as circunstâncias temporárias que justificavam a intervenção contingencial do Poder Judiciário e considerando que a celebração do compromisso arbitral implica, como regra, a derrogação da jurisdição estatal, os autos devem ser prontamente encaminhados ao juízo arbitral, para que este assuma o processamento da ação e, se for o caso, reaprecie a tutela conferida, mantendo, alterando ou revogando a respectiva decisão.

4. Em situações nas quais o juízo arbitral esteja momentaneamente impedido de se manifestar, desatende-se provisoriamente as regras de competência, submetendo-se o pedido de tutela cautelar ao juízo estatal; mas essa competência é precária e não se prorroga, subsistindo apenas para a análise do pedido liminar.

5. Recurso especial provido. (STJ, REsp 1297974 / RJ, $3^{a}$ T., Rel. Min. Nancy Andrighi; julgamento em 12/06/2012) (grifo nosso)

A vista da posição jurisprudencial e da posição da doutrina majoritária percebe-se que o entendimento é de aproveitar-se de todos os meios para garantir a eficácia de uma sentença, e por isso deve prevalecer a harmonia entre a jurisdição estatal e a arbitragem.

É conveniente ressaltar que a Kia, tanto na propositura da ação cautelar quanto na ação principal, deixou claro que não havia renunciado à cláusula compromissória. Do mesmo modo, é necessária a renuncia à convenção arbitral por ambas as partes, o que não ocorreu no caso, pois em nenhum momento os requeridos se manifestaram nesse sentindo.

Além disso, embora a convenção de arbitragem esteja inserida no rol do artigo 267 do Código de Processo Civil, inciso VII, como causa preliminar de extinção de julgamento sem resolução do mérito, pressuposto negativo para afastar a jurisdição estatal, esta não poderia ser arguida pelos requeridos, pois o tribunal arbitral sequer havia sido instaurado, e portanto a jurisdição era do poder judiciário.

Cabe ainda mencionar que o ordenamento jurídico desconsidera a litispendência internacional, tendo o legislador brasileiro previsto expressamente no artigo 90 do código de processo civil que:

"a ação intentada perante tribunal estrangeiro não induz litispendência nem obsta a que a autoridade judiciária brasileira conhece da mesma causa e das que lhe são conexas" 
Esse pensamento pode ser confirmando pelo entendimento jurisprudenciais:

SENTENÇA ESTRANGEIRA - TRAMITAÇÃO DE PROCESSO NO BRASIL -HOMOLOGAÇÃO. O fato de ter-se, no Brasil, o curso de processo concernente a conflito de interesses dirimido em sentença estrangeira transitada em julgado não é óbice à homologação desta última. BENS IMÓVEIS SITUADOS NO BRASIL - DIVISÃO SENTENÇA ESTRANGEIRA - HOMOLOGAÇÃO. A exclusividade de jurisdição relativamente a bens imóveis situados no Brasil - artigo 89, inciso I, do Código de Processo Civil - afasta a homologação de sentença estrangeira a versar a divisão. (STJ, SEC 7209,Tribunal Pleno Rel. Min. Ellen Gracie,julgamento em 30.04.2004)

(...) 9.A existência de ação de seguradora em face da requerente da homologação, em nada interfere no presente procedimento à luz dos artigos 89 e 90 do CPC, posto tratar-se de competência concorrente, versada sobre lide obrigacional.(..) (STJ, Rel. Min. Luiz Fux; SEC 646/US, julgamento em 11.12.2008)

Assim, mesmo quando existe ação perante a justiça brasileira, a homologação da sentença estrangeira não é prejudicada. Como no caso em análise a ação já havia transitado em julgado, nada impediu a homologação da sentença arbitral estrangeira em tudo aquilo que não foi decidido na sentença judicial no Brasil.

Podemos concluir que o Superior Tribunal de Justiça, por meio de todos os seus fundamentos, reafirmou a eficácia da cláusula compromissória. Embora no julgamento para homologação de sentença estrangeira não ocorra o reexame do mérito, a Corte Especial optou por refutar todas as alegações para a não homologação da SEC nº 1. A Corte demonstrou, através de uma fundamentação densa e extensa, que o acordo e todas as providências tomadas pela AMC estavam em consonância com o ordenamento jurídico para fins de homologação e, portanto, prevaleceu a cláusula compromissória arbitral. 


\section{Conclusão}

Após uma passagem pelos primórdios da arbitragem até os dias atuais, que permitiu verificarmos a evolução do instituto principalmente no Brasil, que apesar de possuir norma sobre o tema desde a Constituição Federal de 1824, foi somente com a promulgação de Lei de Arbitragem Brasileira de 1996 que definitivamente a arbitragem recebe seu devido reconhecimento.

Como mencionado, a Lei 9.307/96 trouxe inúmeras novidades, podendo ser destacados: a equiparação da cláusula compromissória ao compromisso arbitral, a equiparação de decisão arbitral nacional à sentença judicial, e o fim do duplo exequatur para fins de homologação de sentença estrangeira.

Em um segundo momento, para uma abordagem mais prática do tema, foi realizada a análise do caso concreto - a SEC $n^{\circ} 1$ - que em razão da profundidade da discussão do caso, permitiu um exame mais detalhado dos pontos tratados na primeira parte e ainda possibilitou apreciação de questões como entendimento sobre o contrato guarda-chuva e os contratos satélites nas joint ventures. Alguns dos princípios, como o da autonomia da vontade, autonomia da cláusula compromissória e da kompetenz-kompetenz foram destacados tanto na Parte I quanto na Parte II por sustentarem a própria essência da arbitragem.

Mesmo que de forma não exaustiva, por meio do apreciação da decisão do STJ, obtivemos a compreensão sobre a autonomia da cláusula compromissória. Prevista pela lei de arbitragem brasileira em seu artigo $8^{\circ}$, aliada ao princípio da kompetenz-kompetenz, afastam, em regra, as tentativas de uma das partes de questionarem a sua validade. Ressaltou-se ainda, o principio da autonomia da vontade, intrínseco às relações contratuais, principalmente quando ambas as partes compartilham do mesmo poder de negociação. Assim, a convenção arbitral inserida em um contrato é reflexo direto desta manifestação de vontade, pois as partes 
escolhem livremente pela adoção da arbitragem como instrumento para resolver seus conflitos.

O ponto chave demonstrado pela decisão do Superior Tribunal de Justiça foi no sentido de confirmar e reafirmar a eficácia da cláusula compromissória e a consequentemente, a sua força vinculante em relação às partes.

Por todo exposto, resta evidente que a Lei Brasileira de Arbitragem está em vigor e suas normas devem e estão sendo cumpridas e respeitadas. O entendimento da Corte Especial na SEC n ${ }^{\circ} .1$ é fruto do amadurecimento da sociedade arbitral no Brasil. A força vinculante da cláusula compromissória devidamente reconhecida e aceita pelos nossos tribunais, apresenta o Brasil como um país seguro e estável para cumprir com as exigências das negociações contemporâneas. 


\section{Bibliografia}

\section{Livros}

ARMELIN, Donald. Tutelas de Urgência e Cautelares - Estudos em homenagem a Ovídio A. Baptista da Silva. ARMELIN, Donald (coord.), Rio de Janeiro: Ed. Saraiva, 201. P.363

ALMEIDA, Ricardo Ramalho (coord.), Arbitragem Interna e Internacional (questões de doutrina e da prática), Rio de Janeiro: Ed. Renovar, 2003.

ARAUJO, Nadia de. Direito Internacional Privado: Teoria e Prática Brasileira. 5aed. Rio de Janeiro: Ed. Renovar, 2011.

BORN, Gary B. International Commercial Arbitration.Vol. I. Kluwer Law International, 2009.

CARMONA, Carlos Alberto. Arbitragem e Processo, um comentário à Lei $n^{o}$. 9.307/96. $3^{\text {a }}$. ed. São Paulo: Ed. Atlas S.A., 2009.

CARMONA, Carlos Alberto. A arbitragem no Brasil no terceiro ano de vigência da Lei n. ${ }^{\circ}$ 9.307/96. In: PUCCI, Adriana Noemi (Coord.). Aspectos atuais da arbitragem: coletânea de artigos dos árbitros do Centro de Conciliação e Arbitragem da Câmara de Comércio Argentino-Brasileira de São Paulo. Rio de Janeiro: Ed. Forense, 2001

CRETELLA Neto, José. Curso de Arbitragem. $1^{\text {a }}$ Ed., Rio de Janeiro: Ed. Forense, 2004.

DOLINGER, Jacob; TIBÚRCIO, Carmen. Direito Internacional Privado (parte especial): Arbitragem Comercial Internacional. Rio de Janeiro: Ed. Renovar, 2003.

DOLINGER, Jacob. Direito Internacional Privado - Contratos e obrigações no direito internacional privado - vol. II. Rio de Janeiro: Ed. Renovar, 2007. 
FOUCHARD, Philippe; GAILLARD, Emmanuel; GOLDMAN, Berthold. On International Commercial Arbitration, org. (Gaillard, Emmanuel, \& Savage, John); Kluwer Law International: Haia, 2010.

MARTINS, Pedro A. Batista. Apontamentos sobre a lei de arbitragem. $1^{\mathrm{a}}$ ed., Rio de Janeiro: Ed. Forense, 2008.

MARTINS, Pedro Batista; GARCEZ, José M. Rossani. Reflexões sobre Arbitragem in Memoriam do Desembargador Cláudio Vianna de Lima. São Paulo: Ed.Ltr, 2002.

LAMY FILHO, Alfredo e PEDREIRA, José Luiz Bulhões. A Lei das S.A.: pressupostos, elaboração, aplicação. Vol. I, $3^{\text {a }}$ Edição, Rio de Janeiro; Ed. Renovar, 1997.

LEMES, Selma Ferreira; CARMONA, Carlos Alberto; MARTINS, Pedro Batista (coordenadores), Arbitragem Estudos em Homenagem ao Prof. Guido Fernando da Silva Soares, In Memoriam; São Paulo:Ed. Atlas S.A. 2007.

LEE, João Bosco. A homologação de Sentença Arbitral Estrangeira: a Convenção de Nova Iorque de 1958 e o Direito Brasileiro de Arbitragem In: LEMES, Selma Ferreira; CARMONA, Carlos Alberto; MARTINS, Pedro Batista (coordenadores), Arbitragem Estudos em Homenagem ao Prof. Guido Fernando da Silva Soares, In Memoriam; São Paulo:Ed. Atlas S.A., 2007, p.177

LOBO, C. A. da Silveira. Uma introdução à arbitragem comercial internacional. In: ALMEIDA, Ricardo Ramalho (org.) Arbitragem interna e internacional: questões de doutrina e da prática. Rio de Janeiro: Ed. Renovar, 2003.

PEREIRA, Caio Mário da Silva. Instituições de Direito Civil - Contratos. Vol. III, 13ª edição. Rio de Janeiro: Ed. Forense, 2009.

PUCCI, Adriana Noemi, Homologação de Sentenças Estrangeiras In: LEMES, Selma Ferreira, CARMONA, Carlos Alberto, MARTINS Pedro 
Batista (coordenadores), Arbitragem Estudos em Homenagem ao Prof. Guido Fernando da Silva Soares, In Memoriam; São Paulo:Ed. Atlas S.A., 2007, p.341-342

ROZAZ, J. C. Fernández; GARCÍA, Rafael Arenas; ASENSIO, Pedro Alberto de Miguel, In: Derecho de los Negocios internationales, $3^{\text {a }}$ edicíon, Ed. Iustel, Madrid, 2011.

VILELA, Marcelo Dias Gonçalves, Arbitragem no Direito Societário; Belo Horizonte: Ed. Mandamentos, 2004.

WALD, Arnoldo. A Evolução do Direito e a Arbitram. In: LEMES, Selma Ferreira; CARMONA, Carlos Alberto; MARTINS, Pedro Batista (coordenadores), Arbitragem Estudos em Homenagem ao prof. Guido Fernando da Silva Soares, In Memoriam; São Paulo. Ed. Atlas S.A., p. 458. 2007.

Black's Law Dictionary, 9th edition, Chief editor Bryan A Garner, West - a thomson business, 2004.

\section{Artigos e Pareceres de Revistas}

BAPTISTA, Luiz Olavo. A joint venture: Uma perspectiva comparatista, Revista de Direito Mercantil 42/39, Abr.-Jun. de 1981. 39-59

BENETI, Sidinei. Arbitragem e tutelas de urgência. In: Revista do Advogado Ano XXVI, No 8, Set. 2006. p.100-108

CARMONA, Carlos Alberto, Contrato de Joint Venture. Contratossatélites que absorvem as previsões constantes do contrato-base. Revogação tácita e revogação expressa de cláusula compromissória. Manifestação de vontade no sentindo de restringir os limites da cláusula compromissória. Autonomia da vontade das partes. Impossibilidade de homologar sentença arbitral estrangeira. Art. 38, II, da lei de arbitragem In: Revista de Arbitragem e Mediação, vol.19 Out-Dez/2008. p. 148-163 ENGLE, Rachel, Comments: Party Autonomy in International Arbitration: Where Uniformity Gives Way to Predictability, 15 Transnat'l Law, 2002. 
MACHADO, Rafael Bicca e JOBIM, Eduardo. A Força Vinculante da cláusula compromissória - jurisprudência comentada. In: Revista de Arbitragem e Mediação n. 11, p.237-243

MARTINS, Pedro Batista, Poder Judiciário-Princípio da autonomia da cláusula compromissória - princípio da competência-competência Convenção de Nova Iorque - Outorga de poderes para firmar cláusula compromissória - determinação de lei aplicável ao conflito - julgamento pelo tribunal arbitral. In: Revista de Arbitragem e Mediação Vol.7, 2005, p. 174-193.

Revista Forense, Rio de Janeiro, v. 15, 195, p. 239

WALD, Arnoldo. Os Meios Judiciais de Controle da Sentença Arbitral. In: Revista de Arbitragem e Medição no. 1, 2004. p 50-51

VALÉRIO, Marco Aurélio Gumieri. Cláusula Compromissória nos contratos de" Joint Venture". In: Revista de Direito Mercantil - vol. 130, São Paulo, Edi. Malheiros, abr.-Jun./2003. p. 151-157

\section{Documentos Retirados da Internet}

LEMES, Selma Maria Ferreira. Parecer: Medidas Cautelares prévias à instauração da arbitragem. - Análise à luz do artigo 19 da Lei de Arbitragem (instituição da arbitragem). Disponível em <http://www.selmalemes.com.br/artigos/artigo_juri29.pdf> (último acesso em 03.11.2012).

Regulamento da Câmara de Comércio Internacional. Disponível em: $<$ http://iccwbo.org/products-and-services/arbitration-and-adr/pre-arbitralreferee/rules-for-a-pre-arbitral-referee-procedure/> (último acesso em 02.11.2012).

Oporto Fazzinga, Silva e Vasconcellos, Fernando. Arbitragem Comercial Internacional. Disponível em $<$ http://sisnet.aduaneiras.com.br/lex/doutrinas/arquivos/080306t.pdf>. (último acesso em 30 de set. 2012). 
$<$ http://redir.stf.jus.br/paginadorpub/paginador.jsp?docTP=AC\&docID=345 889> (último acesso em 12.10.2012).

TAVOLARO, Agostinho Toffoli, Joint Venture. Disponível em <http://www.tavolaroadvogados.com/doutrina/cs372.pdf> (último acesso em 02.11.2012)

BRANCO, Luizella Giardino B. A Arbitragem nos Contratos internacionais. Disponível

em: <http://www.cbsg.com.br/pdf_publicacoes/arbitragem_nos_contratos_inter nacionais.pdf> (último acesso em 02.11.2012).

Code de Procédure Civile, edition originale et seule officielle, L’imprimerie impériale, 1806. Coleção da Universidade de Michigan download de cópia integral diponibilizado pelo Google - Google books service. Dispoível em: http://books.google.com/books?id=ZxAcbGbCmmIC\&oe=UTF-8 (último acesso em 07.11.2012)

\section{Sites útilizados}

www.tjrj.jus.br. (ultimo acesso em 30.10.2012)

www.tjsp.jus.br (ultimo acesso em 30.10.2012)

Www.cbar.org.br (último acesso em 03.11.2012)

www.uncitral.org (último acesso em 03.11.2012)

http://www.iccwbo.org/ (último acesso em 03.11.2012)

www.stj.jus.br (último acesso em 07.11.2012) 
5. Anexo 
SENTENÇA ESTRANGEIRA CONTESTADA N 1 - EX (2007/0156979-5)

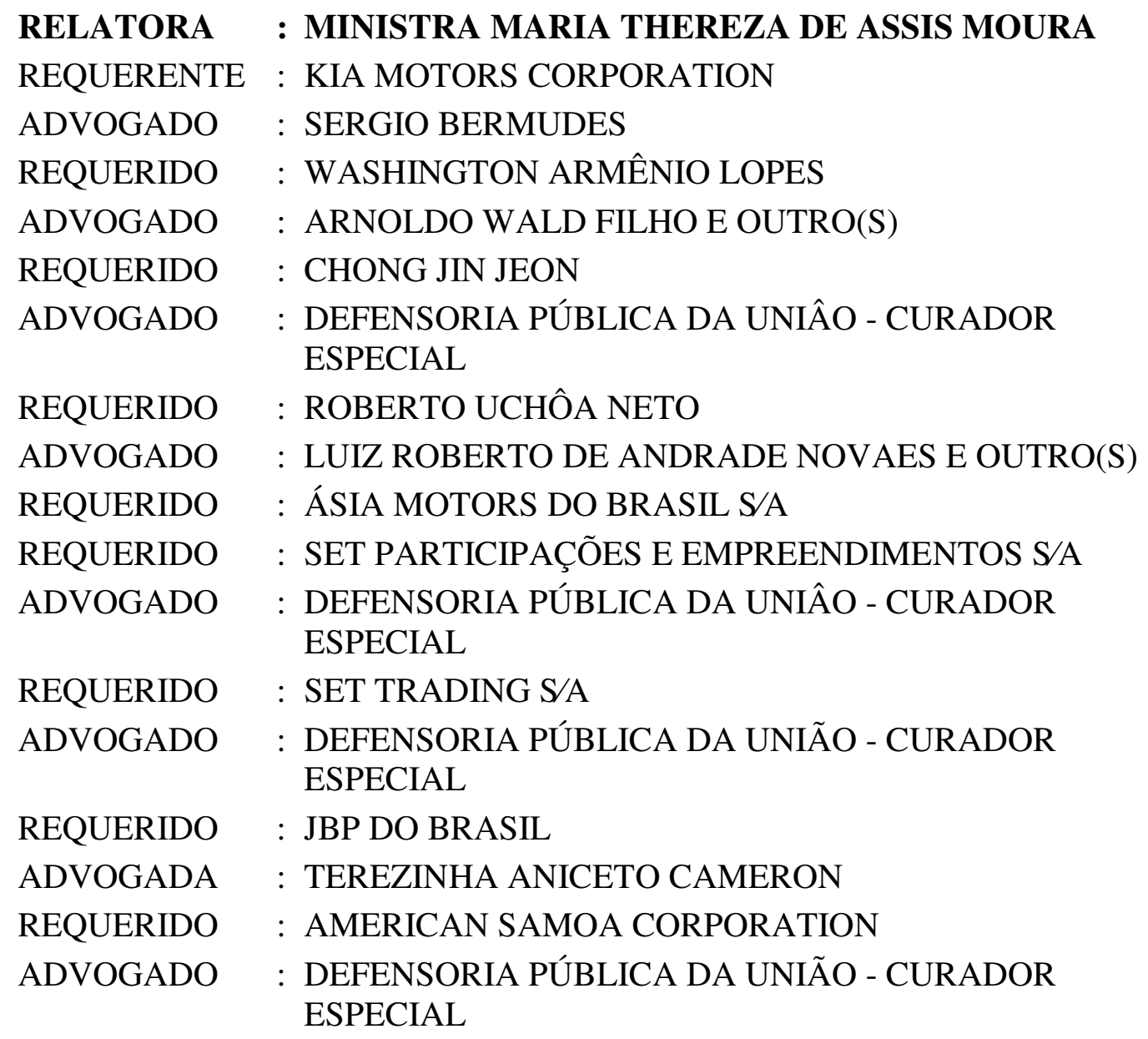

EMENTA

SENTENÇA ARBITRAL ESTRANGEIRA CONTESTADA. PRETENSÃO HOMOLOGATÓRIA A SER DEFERIDA EM PARTE. REQUISITOS DA LEI ATENDIDOS. VÍCIOS DE NEGAÇÃO INEXISTENTES. AMPLA COMPETÊNCIA PARA DIRIMIR CONFLITOS ENTRE OS CONTRATANTES DE JOINT VENTURE.

Sendo lícito o negócio jurídico realizado no Brasil, por partes de legítimo contrato de joint venture, não se lhe pode extrair as consequências jurídicas da quebra do acordado.

CPor mais razão, não se pode afastar a convenção arbitral nele instituída por meio de cláusula compromissória ampla, em que se regulou o Juízo competente para resolver todas as controvérsias das partes, incluindo aí a extensão dos temas 
debatidos, sob a alegação de renúncia tácita ou de suposta substituição do avençado.

Uma vez expressada a vontade de estatuir, em contrato, cláusula compromissória ampla, a sua destituição deve vir através de igual declaração expressa das partes, não servindo, para tanto, mera alusão a atos ou a acordos que não tinham o condão de afastar a convenção das partes.

Ademais, o próprio sentido do contrato de joint venture assinado pelas partes elimina o argumento de que uma delas quis abdicar da instituição de juízo arbitral no estrangeiro.

A revelia não importa em falta de citação, mas, ao contrário, a pressupõe.

O laudo arbitral lavrado por Corte previamente prevista na cláusula compromissória obedece aos requisitos para sua internalização em território pátrio, máxime porque não ofende os ditames dos arts. $3^{\circ}, 5^{\circ}$ e $6^{\circ}$ da Resolução n. ${ }^{\circ}$ 9 desta Corte, devendo, por isso, ser homologado.

Havendo a Justiça brasileira, definitivamente, resolvido controvérsia quanto a um dos temas do pedido de homologação da sentença arbitral, deve a pretensão ser negada quanto a isso por obediência à coisa julgada.

Homologação deferida em parte, com a exclusão dos itens 7 e 10 da decisão arbitral.

\section{ACÓRD̃̃o}

Vistos, relatados e discutidos os autos em que são partes as acima indicadas, acordam os Ministros da Corte Especial do Superior Tribunal de Justiça:

Prosseguindo no julgamento, após o voto-vista do Sr. Ministro Massami Uyeda indeferindo o pedido de homologação, e os votos dos Srs. Ministros Gilson Dipp, Laurita Vaz e Humberto Martins, acompanhando o voto da Sra. Ministra Relatora, a Corte Especial, por maioria, deferiu parcialmente o pedido de homologação, nos termos do voto da Senhora Ministra Relatora. Vencido o Sr. Ministro Massami Uyeda. Os Srs. Ministros Raul Araújo, Mauro Campbell Marques, Paulo de Tarso Sanseverino, Cesar Asfor Rocha, Gilson Dipp, Francisco Falcão, Nancy Andrighi, Laurita Vaz e Humberto Martins votaram com a Sra. Ministra Relatora.

Não participaram do julgamento os Srs. Ministros Felix Fischer, Teori Albino Zavascki, Castro Meira e Arnaldo Esteves Lima.

Ausentes, justificadamente, os Srs. Ministros Cesar Asfor Rocha, Eliana Calmon, Francisco Falcão e João Otávio de Noronha.

Brasília, 19 de outubro de 2011(Data do Julgamento).

Ministro Ari Pargendler

Presidente

Ministra Maria Thereza de Assis Moura

Relatora 
SENTENÇA ESTRANGEIRA CONTESTADA No 1 - KR (2007/0156979-5)

(f)

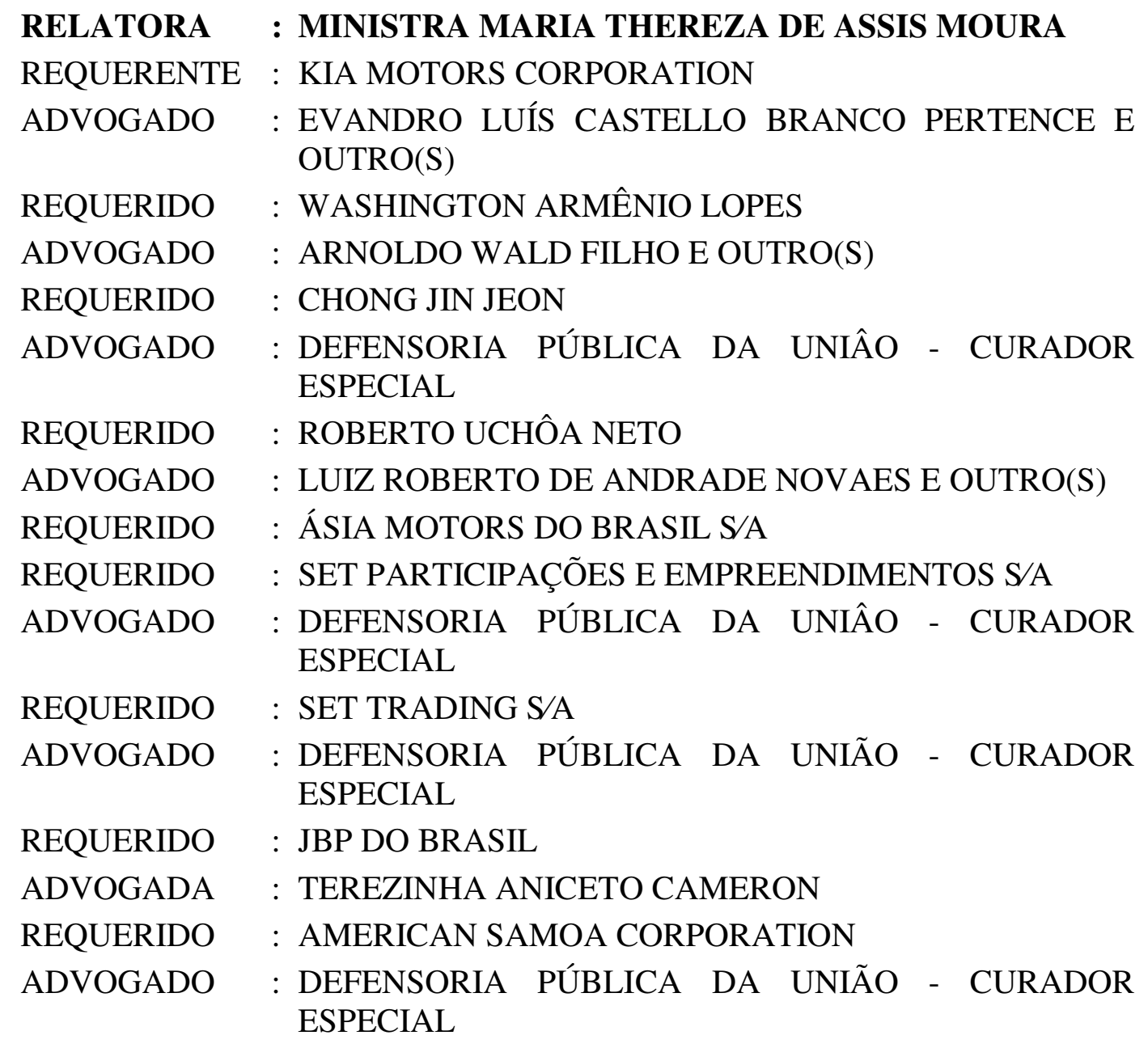

\section{RELATÓRIO}

MINISTRA MARIA THEREZA DE ASSIS MOURA

(Relatora):

Cuida de pedido de homologação de sentença arbitral estrangeira formulado por KIA MOTORS CORPORATION, tendo como requeridos $1^{\circ}$ WASHINGTON ARMÊNIO LOPES; $2^{\circ}$ CHONG JIN JEON; $3^{\circ}$ ROBERTO UCHÔA NETO; $4^{\circ}$ ASIA MOTORS DO BRASIL S/A (AMB); $5^{\circ}$ SET PARTICIPAÇÕES E EMPREENDIMENTOS S/A; $6^{\circ}$ SET TRADING S/A (SETCO); $7^{\circ}$ JBP DO BRASIL; $8^{\circ}$ AMERICAN SAMOA CORPORATION. 
A decisão que se busca homologar é da lavra de Tribunal Arbitral, composto de três árbitros, instituído na cidade de Nova Iorque e regido pelas normas de arbitragem da Câmara Internacional de Comércio, cujo processo foi formalizado em 24 de dezembro de 2001 por proposta da ora Requerente, na condição de substituta da ASIA MOTORS COMPANY (AMC), que detinha negócio com os Requeridos oriundo de contrato de joint venture (fls. 75/172) assinado em 24 de junho de 1997.

Em síntese, a questão debatida na Corte Arbitral relacionava-se a conflito em torno do referido negócio jurídico, sendo que o laudo que se pretende homologar, assim definiu a contenda (fls. 988994):

1. O Tribunal Arbitral decide não ter competência para decidir sobre pedidos resultantes do MOU. Tem competência para decidir sobre todos os demais pedidos. Não está impedido por prescrição, exceto no que se refere ao pedido sobre a subscrição inicial de $51 \%$ das ações da AMB ter ocorrido em ou próximo de 10 de agosto de 1997, declarada nula com base no Artigo 147 do Código Civil Brasileiro de 1916, assim como o pedido de indenização dela decorrente. O Reclamante tem bases para impetrar ações processuais em todas as suas reclamações.

2. O Tribunal Arbitral declara que a AMB inadimpliu suas obrigações em relação ao pagamento dos créditos negociais $\mathrm{D} / \mathrm{A}$ devidos à Reclamante, relativo aos veículos recebidos pela AMB. Como consequência, o Tribunal Arbitral determina à AMB o pagamento, à Reclamante, do valor de US\$ 79.058.751,00, que representa o valor dos créditos pendentes de pagamento devidos pela AMB a Reclamante, acrescidos de juros a taxa legal de $6 \%$ ao ano, contados da data de cada um dos vencimentos até pagamento integral.

3. O Tribunal Arbitral declara que os Reclamados N. ${ }^{\circ}$ s. 1, 2, a AMB e a Set violaram o JVA, particularmente seus artigos 2.3, 2.4, 3.3, 4.1, 4.2, 4.3, 7, 14.2: (i) exercendo controle sobre a AMB ao mesmo tempo em que excluíam a $\mathrm{AMC}$ e a KIA de qualquer participação significativa de gestão; (ii) deixando de manter contabilidade e registros financeiros corretos da AMB; (iii) impedindo que a AMC e a KIA pudessem verificar a contabilidade e registros financeiros da AMB; (iv) conduzindo transações de má fé com partes relacionadas, através das quais se apropriaram fraudulentamente do valor econômico da AMB e deles próprios; e (v) deixando de agir em boa fé e corretamente em relação à AMC e à KIA; e que o Reclamante tem direito de ser indenizado pelas perdas e danos incorridos e a incorrer no futuro, como consequência daquelas violações.

4. Em consequência de idênticas violações, o Tribunal Arbitral também declara que fica rescindido o JVA, com base em seu artigo 12.1.2.

5. O Tribunal Arbitral declara que os Reclamados N. ${ }^{\circ}$ s. 1, 2, a AMB, a Set e a JBP se envolveram, de forma fraudulenta, em uma simulação de aumento de capital, com a assistência da Bambari e da American Samoa.

6. O Tribunal Arbitral declara que, de acordo com o artigo 3.3. do JVA, o aumento de capital da AMB, de março de 1998, exigia a aprovação do Tribunal 
Distrital de Seul; declara ainda que o mesmo Tribunal Distrital aprovou um aumento de capital no valor de $\mathrm{R} \$ 223$ milhões pela Set, de acordo com o Contrato de Mútuo (Mutual Agreement) com duas páginas datado de 27 de fevereiro de 1998, porém não foi solicitado pela AMB a aprovar o aumento de capital no valor de US\$ 232 milhões.

7. O Tribunal Arbitral declara que o boletim de subscrição no valor de $\mathrm{R} \$$ 232.310.204,00, datado de 2 de marco de 1998, o qual os Reclamados alegam obrigar a Reclamante a efetuar um aporte de capital no valor de $\mathrm{R} \$$ 232.310.204,00 para a AMB fica nulo e sem efeito, uma vez que a AMC carecia da capacidade legal para incorrer na obrigação e ainda de acordo com o artigo 147 (II) do Codigo Civil Brasileiro de 1916, porque ocorrera devido a ilegitimidade resultante de erro, fraude, coerção e simulação. Em consequência, o painel Arbitral declara que a AMC não tem qualquer obrigação de efetuar o pagamento citado de $\mathrm{R} \$ 232.310 .204,00$ referente ao boletim de subscrição.

8. O Tribunal Arbitral declara que os Reclamados N. ${ }^{\circ}$ s 1 e 2 e a Set violaram o JVA e o Contrato de Mútuo (Mutual Agreement) celebrado em 27 de fevereiro de 1998, ao deixar de pagar todos os valores pedidos pela AMC relativos ao aumento de capital; além disso, que a AMB violou o JVA por meio de forçar um plano para aumento de capital contra o Reclamante e por meio da execução do patrimônio do Reclamante no Brasil, com o fim de forçar o Reclamante a cumprir supostas obriga9oes de realizar um aporte de $\mathrm{R} \$ 232$ milhões.

9. O Tribunal Arbitral declara que a AMB, os Reclamados N. ${ }^{\circ}$ s. 1 e 2, a Set e a JBP, a Bambari e a American Samoa são responsáveis, solidária e isoladamente, pela obrigação de indenizar o Reclamante por todos os danos e perdas incorridas pelo Reclamante em consequência do aumento de capital fraudulento da AMB, datado de marco de 1998, inclusive por todos os valores que o Reclamante tenha sido obrigada a pagar resultantes de sua subscrição do boletim de subscrição datado de 2 de marco de 1998, no valor de $\mathrm{R} \$ 232.310,204,00$.

10. O Tribunal Arbitral declara que a Set permanece obrigada a cumprir a totalidade da subscrição do aumento de capital da AMB, no valor de R\$ 223.200.000.00.

11. O Tribunal Arbitral declara que os Reclamados N. ${ }^{\circ}$ s 1 e 2, direta e indiretamente, por meio da Set, foram sempre os Acionistas Controladores da $\mathrm{AMB}$, de acordo com o artigo 116 da Lei das Sociedades Anônimas; que, naquela capacidade, violaram seus deveres legais em relação à AMB e seus acionistas e que, como consequência, o Reclamante terá o direito de ser indenizada pelos Reclamados N. ${ }^{\circ} 1$ e 2 pelas perdas e danos sofridos e a sofrer em resultado daquelas violações.

12. O Tribunal Arbitral declara que os Reclamados N. ${ }^{\circ}$ s 1 e 2, direta ou indiretamente, por meio da Set, na qualidade de administradores da AMB, violaram seus deveres legais em relação à $\mathrm{AMB}$ e a Reclamante e que, como consequência, o Reclamante terá o direito de ser indenizada pelos Reclamados N. ${ }^{\circ}$ s 1 e 2 e pela Set em razão das perdas e danos sofridos e a sofrer em resultado daquelas violações. 
13. O Tribunal Arbitral ordena ainda que a AMB pague à Reclamante o valor de US\$ 10.000.000,00 como honorários pela assistência técnica devida pela AMB à Reclamante, de acordo com o Contrato de Cooperação Técnica (TCA), acrescido de uma multa de $10 \%$, de acordo com o artigo 14.12 do TCA, alem dos juros a taxa contratual de $1 \%$ ao mês, contados de 13 de março de 1998 até a data do pagamento integral.

14. O Tribunal Arbitral ordena que os Reclamados - exceto os N. ${ }^{\circ}$ s 3 e 5 paguem, solidária e isoladamente à Reclamante o valor de US\$ 30.000,00, por danos morais.

15. O Tribunal Arbitral declara que o Reclamado N. 3 não violou o JVA em qualquer de seus aspectos e que não é culpado de qualquer conduta ilegítima e, em consequência, não deve, à Reclamante, em qualquer de suas capacidades (seja como acionista ou administrador da AMB). Todos os pedidos apresentados contra ele ficam, portanto, indeferidos.

16. O Tribunal Arbitral chega à idêntica decisão no que respeita a Set Trading S.A, Reclamada N. 5.

17. O Tribunal Arbitral condena os Reclamados N. ${ }^{\circ}$ s. 1,2,4,6,7,8 e 9, solidária e isoladamente, ao pagamento, a Reclamante, do valor de US\$ 427.777,00 a de US\$ 3.5 milhões relativos às custas de honorários da arbitragem.

18. O Tribunal Arbitral condena o Reclamante ao pagamento, aos Reclamado N. ${ }^{\circ}$ 3 , o valor de US\$ 68.333,00 e de US\$ 500.000,00, relativos às custas e honorários da presente arbitragem. Condena ainda o Reclamante a pagar ao Reclamado N. 5 o valor de US\$ 50.000,00 no que se refere às mesmas custas e honorários.

19. Todos os demais pedidos ficam indeferidos."

Com a autuação da peça vestibular, às fls. $2 / 12$, na qual a Requerente sustenta a presença dos requisitos legais e pugna pela homologação, teve início ao primeiro procedimento originado no âmbito desta Corte de feitos dessa natureza, após a vigência da Emenda 45 da Constituição Federal, sendo os autos distribuídos ao Ilustre e já aposentado Ministro José Delgado, passando à atribuição desta Relatora em $1 \% / 2008$.

Em obediência aos ditames da Resolução n. ${ }^{\circ} 10$ deste Tribunal, foi concedida vista ao Ministério Público Federal e, posteriormente, se procedeu à citação dos Requeridos, devendo-se destacar ainda: o primeiro Requerido (Washington Armênio Lopes), devidamente citado, apresentou contestação às fls. 1679/1739, além disso, ofereceu resposta à réplica de fls. 1748/1764, fazendo-se acompanhada de parecer do professor Carlos Alberto Carmona, às fls. 1707/1739, e pode apresentar memoriais escritos em audiência com esta Relatora.

De forma resumida, são os temas da contestação desse Requerido:

a) incompetência do Tribunal Arbitral em face de três circunstâncias: 
$1^{\text {a) }}$ superação da cláusula compromissória, instituída no contrato de joint venture, por deliberações posteriores, notadamente o acordo de acionistas e o contrato social, que, assinados logo depois do contrato inicial, não previram a convenção arbitral;

$2^{\text {a) }}$ o contexto da lide ajuizada no Tribunal Arbitral estava fora da convenção arbitral, na medida em que a cláusula compromissória somente abarcava as controvérsias que se relacionassem ao exercício dos direitos dos acionistas tratados no Capítulo 4 do contrato respectivo, que cuidava acerca unicamente da opção de compra e venda de ações.

$3^{\text {a) }}$ revogação tácita da convenção arbitral pela vontade das partes ao se submeterem à competência da Justiça brasileira, em ação cautelar e em ação de conhecimento, controvérsia acerca de deliberações assembleares tomadas em 2/3/1998. O Requerido sustenta, in casu, a hipótese de renúncia à cláusula compromissória por parte da Requerente, autora dos procedimentos judiciais.

b) Falta de citação das empresas American Samoa Corporation e Bambari International S/A no processo de arbitragem.

Com relação a esses pontos, a Requerente, em denominada réplica, faz acostar aquilo que seria a comprovação da citação das empresas American Samoa e Bambari International (fl. 1772), bem assim aduz que os temas aventados pelo primeiro requerido, sobretudo com relação à incompetência do Tribunal Arbitral, diz respeito ao mérito, na medida em que necessita da análise do direito material discutido na sentença homologanda. Diz que não é possível reabrir, em sede de procedimento de homologação, a controvérsia suscitada e resolvida pela Corte Internacional acerca do alcance das cláusulas do contrato de parceria.

Sobre a questão da superação do acordo de joint venture pelo acordo de acionista e pelo estatuto social da empresa constituída pela partes, ressalta que estes dois acordos, assinados no mesmo dia da avença principal, foram firmados com obediência ao contrato principal (JVA), na hipótese, tido como contrato "guarda chuva", porque era o acordo que abrigava e ditava todos os acordos posteriores, não podendo ser por estes substituídos.

De outro lado, contesta a afirmação do primeiro requerido no tocante à existência de renúncia à convenção arbitral, asseverando que a Kia, tanto na medida cautelar quanto na ação declaratória (principal), ressalvou expressamente que não se tratava de renúncia, porque, naquele momento, era medida necessária para coibir abusos dos acionistas brasileiros.

Com o julgamento definitivo das referidas ações depois de lavrada a decisão da Corte Arbitral, a Requerente sugere a homologação parcial, deixando de fora os itens 7 e 10 do laudo.

Dentre os demais requeridos, embora citados, cinco não compareceram aos autos para contestar, razão de ser nomeada a Defensoria Pública, na condição de curadora especial, para a defesa de Chong Jin Jeon, Ásia Motors do Brasil S/A, Set Participações e Empreendimentos S/A, Set Trading e America Samoa, sendo 
apresentada contestação "por negativa geral" à pretensão homologatória, conforme às fls. 1540/1542 e 1824/1827.

Já a Requerida JBP do Brasil, citada, fez encaminhar instrumento procuratório, seguido de substabelecimento, respectivamente, às fls. 1340/1343 e 1619/1621, porém, os Ilustres patronos constituídos não subscreveram qualquer resposta ao pedido de homologação.

Por fim, o Requerido Roberto Uchoa, em petição às fls. 1252/1253, apresentou concordância com o pedido de homologação.

O Ministério Público Federal, instado a manifestar-se, opinou às fls. 1854/1857, cujo parecer subscrito pelo Ilustre Subprocurador-Geral da República Edson Oliveira de Almeida foi no sentido da homologação parcial do pedido, devendo-se rejeitar os itens 7 e 10 do laudo arbitral homologando, em virtude do conflito existente com a decisão proferida na ação de conhecimento proposta na Justiça Comum da Bahia, da qual resultou em recurso especial julgado por esta Corte, no âmbito da Terceira Turma, autuado como REsp. n. ${ }^{\circ}$ 649.711/BA, cujo acórdão foi assim sumariado:

"Declaratória e cautelar. Joint venture. Assembléia geral de acionistas. Aumento de capital. Nulidade. Representação.

1. As nulidades de pleno direito são vícios insanáveis. Por isso, no caso presente, tem legitimidade a própria parte que outorgou a procuração vir a juízo e reclamar a declaração de nulidade absoluta de ato praticado pelo mandatário em assembléia de acionistas.

2. Nulos os atos praticados por mandatário na assembléia em que se aumentou o capital social, já que: a) a empresa mandante é estrangeira e não está autorizada a funcionar no Brasil, embora acionista da empresa ré, ausente representação nos termos do Decreto $n^{\circ} 2.627 / 40 ;$ b) a representação não preenche os requisitos exigidos no art. $126, \S 1^{\circ}$, da Lei $n^{\circ} 6.404 / 76$.

3. Recurso especial conhecido e provido." (REsp 649711/BA, Rel. Ministro ANTÔNIO DE PÁDUA RIBEIRO, Rel. p A Acórdão Ministro CARLOS ALBERTO MENEZES DIREITO, TERCEIRA TURMA, julgado em 06062006, DJ 07/08/2006, p. 219)

Registre-se que a referida demanda, advinda da Justiça Baiana, iniciou-se em janeiro de 2000 (31/1/2000), por meio de medida cautelar, da qual se seguiu, em 19/2/2000, a ação principal com pretensão declaratória de nulidade de assembleia geral extraordinária realizada pelos acionistas da Asia Motors do Brasil S/A, ocorrida em 2 de março de 1998, e na qual foi aprovado aumento de capital desta empresa objeto do contrato de joint venture ora examinado.É o relatório. 
SENTENÇA ESTRANGEIRA CONTESTADA No 1 - KR (2007/0156979-5)

(f)

\section{EMENTA}

SENTENÇA ARBITRAL ESTRANGEIRA CONTESTADA. PRETENSÃO HOMOLOGATÓRIA A SER DEFERIDA EM PARTE. REQUISITOS DA LEI ATENDIDOS. VÍCIOS DE NEGAÇÃO INEXISTENTES. AMPLA COMPETÊNCIA PARA DIRIMIR CONFLITOS ENTRE OS CONTRATANTES DE JOINT VENTURE.

Sendo lícito o negócio jurídico realizado no Brasil, por partes de legítimo contrato de joint venture, não se lhe pode extrair as consequências jurídicas da quebra do acordado.

CPor mais razão, não se pode afastar a convenção arbitral nele instituída por meio de cláusula compromissória ampla, em que se regulou o Juízo competente para resolver todas as controvérsias das partes, incluindo aí a extensão dos temas debatidos, sob a alegação de renúncia tácita ou de suposta substituição do avençado.

Uma vez expressada a vontade de estatuir, em contrato, cláusula compromissória ampla, a sua destituição deve vir através de igual declaração expressa das partes, não servindo, para tanto, mera alusão a atos ou a acordos que não tinham o condão de afastar a convenção das partes.

Ademais, o próprio sentido do contrato de joint venture assinado pelas partes elimina o argumento de que uma delas quis abdicar da instituição de juízo arbitral no estrangeiro.

A revelia não importa em falta de citação, mas, ao contrário, a pressupõe.

O laudo arbitral lavrado por Corte previamente prevista na cláusula compromissória obedece aos requisitos para sua internalização em território pátrio, máxime porque não ofende os ditames dos arts. $3^{\circ}, 5^{\circ}$ e $6^{\circ}$ da Resolução n. ${ }^{\circ}$ 9 desta Corte, devendo, por isso, ser homologado.

Havendo a Justiça brasileira, definitivamente, resolvido controvérsia quanto a um dos temas do pedido de homologação da sentença arbitral, deve a pretensão ser negada quanto a isso por obediência à coisa julgada.

Homologação deferida em parte, com a exclusão dos itens 7 e 10 da decisão arbitral. 
Peço escusas aos meus pares, mas o caso merece, em razão da profundidade da discussão proposta pelas partes, uma abordagem minudente, fugindo um pouco da análise delibatória comum ao procedimento de homologação.

Começo por fazer uma nova exposição, agora tendo como cenário o próprio negócio realizados pelas partes, com a finalidade de facilitar a compreensão dos argumentos e, por conseguinte, esclarecer com mais vigor o sentido da definição do quanto pedido.

ASIA MOTORS COMPANY (AMC), empresa coreana de automóveis, com sede em Seul, a qual restou incorporada pela KIA MOTORS CORPORATION, ora Requerente, realizou contrato de parceria, em 24 de junho de 1997, denominado joint venture (fls. 75/172), com os três primeiros requeridos, que detinham o controle societário das empresas Requeridas de $n^{\circ}{ }^{\circ} \mathrm{s} 4 \% 8^{\circ}$, empresas essas participantes do acordo na condição de intervenientes.

Em síntese, a negociação visava expandir as vendas de veículos da ASIA MOTORS no mercado brasileiro e na América Latina, conforme se lê da finalidade da parceria, naquilo que interessa (fls. 78/118):

"CONSIDERANDO QUE A AMC possui ampla e valiosa tecnologia e experiência reconhecida mundialmente na fabricação de automóveis;

CONSIDERANDO QUE A AMC deseja expandir suas operações no mercado brasileiro;

CONSIDERANDO QUE A AMB tem obtido êxito na comercialização e distribuição dos produtos da AMC no mercado brasileiro;

CONSIDERANDO QUE os Acionistas Brasileiros possuem conhecimento e experiência na comercialização dos produtos da AMC no Brasil;

CONSIDERANDO QUE A SET, SETCO e os Acionistas Brasileiros controlam juntos a AMB;

CONSIDERANDO QUE A AMB se tornou parte do sistema automotivo brasileiro, de acordo com as Normas Automotivas e Qualificação de Regulação MICT/SP/N ${ }^{\circ}$ 03696, emitidas em 8 de abril de 1996, ("Normas Automotivas"), pela Secretaria de Política Industrial do Ministério da Indústria, Comércio e Turismo");

CONSIDERANDO QUE A AMC e os Acionistas Brasileiros decidiram estabelecer uma joint venture no Brasil e desejam determinar os termos e condições que regularão sua relação como sócios de joint venture com objetivos de participar do mercado automotivo no Brasil;

CONSIDERANDO QUE tal joint venture será realizada pela AMB, que após sua separação se tornará uma joint venture, doravante referida como a "EMPRESA"; 
CONSIDERANDO QUE A SET, A SETCO e os Acionistas Brasileiros desejam que a AMC se torne um acionista da EMPRESA por meio da subscrição das novas ações a serem emitidas pela EMPRESA na Data de Fechamento....

ORA, PORTANTO, em contraprestação às premissas e convenções mútuas neste contidos, as partes concordam com o que se segue:

$1.1 \mathrm{O}$ objetivo deste Acordo é fornecer as normas que regulamentarão a relação das partes na empresa, que será financiada, operada e administrada de acordo com os termos e condições estabelecidos neste Acordo, no Estatuto da EMPRESA e no Acordo de Acionistas.

2.2 O principal objetivo da EMPRESA será concentrar-se na venda de veículos nos mercados do Brasil e do MERCOSUL, que as partes reconhecem ter um potencial significativo e inexplorado para expandir as vendas de veículos. Para os fins deste Acordo, os países do MERCOSUL incluem não apenas os membros atuais, isto é, Paraguai, Argentina, Uruguai e Brasil, como também futuros paísesmembros e associados.

2.3. O Estatuto Social da EMPRESA: O Estatuto Social da EMPRESA (o "Estatuto") será na forma da minuta anexa a este como Anexo II e será assinada pela AMC e os Acionistas Brasileiros na Data de Fechamento (como definido no Artigo 11.1 abaixo). O Estatuto pode ser alterado periodicamente, em conformidade com suas disposições e com as disposições do Acordo de Acionistas referido no Artigo 2.4 abaixo.

2.4. O Acordo de Acionistas: A AMC e os Acionistas Brasileiros, pelo presente, concordam expressamente que o Acordo de Acionistas seja assinado na Data de Fechamento (como definido no Artigo 11.1 abaixo) na forma da minuta anexada a este como Anexo.

3.2.2. De forma a permitir a participação do Governo da Bahia na EMPRESA, a AMC concorda em votar a favor de uma emissão de debêntures, ações preferenciais ou porá qualquer tipo de título mobiliário da EMPRESA mediante termos e condições a serem acordados mutuamente, contanto que as seguintes condições sejam atendidas de forma cumulativa: (i) A AMC permanecerá como portadora de cinquenta e um por cento $(51 \%)$ das ações com direito a voto e (ii) os Acionistas Brasileiros permanecerão como portadores de quarenta e nove por cento (49\%) das ações com direitos a voto.

3.3. Aumentos de capital, empréstimos, garantias, créditos ou adiantamentos posteriores semelhantes à EMPRESA e seus respectivos termos e condições serão determinados no Plano Geral de Negócios a ser aprovado pelas partes antes da data de fechamento (o "Plano Geral de Negócios").... 
4.1. Princípio básico: As partes, pelo presente, concordam expressamente em fazer com que seus respectivos representantes e em envidar seus melhores esforços para fazer com que os diretores, gerentes, administradores, funcionários, representantes e agentes da EMPRESA observem, durante a existência deste Acordo, os procedimentos operacionais estabelecidos abaixo.

4.2. Livros, registros e relatórios contábeis: A EMPRESA manterá seus livros e registros em conformidade com os princípios contábeis geralmente aceitos e com as normas e leis brasileiras. Tais registros e documentação de apoio refletirão precisamente as operações financeiras da EMPRESA e estarão sempre disponíveis para inspeção por qualquer uma das partes ou seus nomeados durante as horas normais de trabalho sem interferir no curso normal dos negócios da EMPRESA....

4.3. Administração. As partes concordam que a EMPRESA será administrada pelo Conselho de Administração composto por sete (7) membros e pela Diretoria composta por sete (7) membros a serem escolhidos pelo Conselho de Administração. O Conselho de Administração e a Diretoria serão nomeados, se reunirão e decidirão em conformidade com o Estatuto da EMPRESA e com o Acordo de Acionistas.

5.1. De acordo com as Normas Automotivas e com o Memorando de Entendimento assinado com o governo da Bahia em 12 de novembro de 1996 ("Memorando de Entendimento"), a AMC e os Acionistas Brasileiros assumiram a obrigação de construir uma fábrica no Estado da Bahia para a fabricação e montagem de veículos, peças e componentes.

5.1.1. A AMC auxiliará a EMPRESA, seu Conselho de Administração e sua Diretoria em relação à parte técnica do projeto, que incluirá, entre outros aspectos, aqueles relacionados à engenharia, arquitetura, logística, produção, processos industriais, tecnologia competitiva e alta tecnologia, pessoal, qualidade e adaptação de conceito aos padrões brasileiros. A AMC será responsável pelo fornecimento de tecnologia e treinamento de pessoal, contanto que tal assistência, fornecimento e treinamento sejam regidos pelo Contrato de Cooperação Técnica (TCA), Contrato de Licença de Patente e Contrato de Fornecimento de Peças especificados no Artigo 6.2. abaixo.

5.2. Os Acionistas Brasileiros auxiliarão a EMPRESA, seu Conselho de Administração e sua Diretoria em relação às relações governamentais, a parte financeira e comercial da operação, que inclui, entre outras atividades, o gerenciamento de fundos da EMPRESA, venda de produto, formação de preços, política de marketing e também a implementação e desenvolvimento de uma rede de revendedores, que garantirá as vendas de veículos importados até que a fábrica inicie a produção, e depois a venda de veículos fabricados no Brasil. Os revendedores devem ser capazes de garantir a distribuição de veículos produzidos no Brasil. 
6.1. Dentro de um prazo de trinta (30) dias a partir desta data, a AMC e os Acionistas Brasileiros concluirão as negociações sobre os termos e condições do Contrato de Cooperação Técnica (TCA), Contrato de Fornecimento de Peças, Contrato de Licença de Patente, que refletirão o fornecimento atual e futuro da tecnologia da AMC e a licença de propriedades intelectuais à EMPRESA.

10.2.9. A consumação de todos os negócios contidos neste não prejudicam nem prejudicarão, de nenhuma forma, a existência contínua da EMPRESA sob as Normas Automotivas ou sob o Memorando de Entendimento assinado com o governo do Estado da Bahia, como definido por legislação aplicável a seus respectivos objetos.

12.1. Este contrato entrará em vigor na data de sua assintura por todas as partes e permanecerá em pleno vigor e efeito enquanto os Acionistas Brasileiros permanecerem como acionistas da EMPRESA com pelo menos vinte e cinco por cento $(25 \%)$ de participação na EMPRESA. Este Contrato pode ser rescindido nos seguintes casos:

12.1.1. unilateralmente, por qualquer uma das partes, antes da Data de Fechamento, por qualquer razão;

12.1.2. mediante notificação pela parte não inadimplente no caso de um inadimplemento material deste Acordo ou de qualquer outro contrato mencionado neste por uma das partes, sujeito a um período de reparação de trinta (30) dias.

$12.3 \ldots$

(...)

14.1. As partes concordam que este Contrato será regido e interpretado de acordo com as leis da República Federativa do Brasil.

14.2. É intenção das partes cumprir as disposições deste Acordo em conformidade com os princípios de boa fé e negociação justa e para respeitar e observar o espírito e a redação deste Acordo. As partes envidarão seus melhores esforços para entrar em acordo amigável com relação a qualquer conflito que surja deste Acordo, ou que seja a ele relacionado."

O contrato de joint venture trouxe, ainda, a seguinte convenção arbitral e cláusula compromissória (fl. 114):

"14.3. Qualquer conflito ou reclamação que surja deste Acordo, ou que a ele se relacione, incluindo a interpretação, aplicação e rescisão deste Acordo, e que não possa ser resolvido amigavelmente entre as partes, será resolvido por arbitragem compulsória, em conformidade com as Regras de Conciliação e Arbitragem da Câmara Internacional do Comércio ("ICC"). 
14.4. O processo de arbitragem ocorrerá na cidade de Nova York, estado de Nova York, Estados Unidos da América ou outra cidade e país e será conduzido na língua inglesa. Os conflitos serão resolvidos por três árbitros. Os Acionistas Brasileiros e a AMC nomearão, cada um, um árbitro. O Tribunal Arbitral da Câmara Internacional do Comércio nomeará o terceiro árbitro.

14.5. As partes reconhecem que a decisão do árbitro será final e obrigatória com relação a vereditos, sem direito a apelação em nenhum tribunal de nenhuma competência. As despesas do árbitro serão divididas igualmente pelas partes, a não ser que o árbitro determine que as despesas sejam calculas de outra forma.

15.4. Este Acordo, juntamente com seus Anexos ora referidos, contém todos os acordos entre as partes deste em relação às questões do presente e substitui todos os acordos, declarações e negociações anteriores escritos ou verbais das partes."

Com relação às cláusulas dos referidos anexos, especialmente no tocante ao denominado ACORDO DE ACIONISTAS (fls. 120 e seguintes), ainda se pode extrair como compromisso específico da arbitragem e outros (fl. 147/151):

"7.1. Este acordo será regido e interpretado em conformidade com as leis da República Federativa do Brasil. As partes elegem o foro da cidade de São Paulo, Estado de São Paulo, renunciando a qualquer outro, não importando os privilégios inerentes, para resolver quaisquer dúvidas ou disputas que surjam neste acordo.

7.2. É intenção das partes cumprir as disposições deste Acordo em conformidade com os princípios de boa fé e negociação justa, bem como observar e respeitar a essência e o conteúdo deste Acordo. As partes se esforçarão ao máximo para resolver as disputas entre elas de forma amigável que surjam deste Acordo, ou que se relacionem a ele.

7.3. Qualquer controvérsia ou reclamação que surja do exercício dos direitos dos Acionistas, ou que a eles se relacione, sob o Capítulo 4 e suas sub-seções, que não possa ser resolvida amigavelmente entre as partes, será resolvida por arbitragem compulsória em conformidade com as Normas de Conciliação e Arbitragem da Câmara Internacional do Comércio. ("ICC").

8.4. Caso qualquer uma das obrigações contidas neste não seja cumprida por qualquer uma das partes, a parte prejudicada poderá executar especificamente o Acordo de Acionistas, com base nas disposições do Artigo 118, parágrafo terceiro, da Lei das S. ${ }^{a}$ e nas disposições dos Artigos 639, 640 e 641 do Código de Processo Civil Brasileiro.

8.5. Sem prejuízos às disposições da Cláusula 8.4. acima, cada parte se compromete a compensar a outra por perdas, danos, custos e despesas diretas resultando da falha em seguir as obrigações acordadas neste. A não ser que de 
outra forma estabelecido neste, as partes não serão responsáveis em relação a outra parte ou a terceiros por quaisquer danos consequentes indiretos.

8.6. As partes concordam, no entanto, que se qualquer uma das partes não cumprir qualquer uma das obrigações contidas neste Acordo, a parte prejudicada notificará a parte em falta, por escrito, de forma que possa sanar tal falta dentro de trinta (30) dias, contados da data de recebimento da notificação.

8.7. A EMPRESA concorda expressamente com todos os termos e condições neste contidos. Além disso, a EMPRESA se compromete a atuar em conformidade e a tomar todas as medidas necessárias para assegurar a conformidade com todos os termos e condições contidos no Acordo de Acionistas, incluindo a conformidade de terceiros que possa adquirir ou subscrever ações do capital social da EMPRESA, como estabelecido neste.

8.9. Quaisquer alterações ou modificações a este Acordo de Acionistas será por escrito e assinado pelos representantes autorizados da AMC e pelos Acionistas Brasileiros. A não execução de uma das partes, a qualquer momento, de qualquer disposição deste Acordo de Acionistas não será interpretado como uma renúncia de tal disposição e não afetará, de forma alguma, a validade do Acordo de Acionistas ou qualquer parte relativa ou o direito de tal parte de executar toda e cada disposição. Nenhuma renúncia de nenhuma infração deste Acordo de Acionistas constituirá uma renúncia de qualquer outra infração ou de infração subsequente.

8.10. Caso qualquer disposição deste Acordo ou parte dele seja considerada inválida ou inexequível em conformidade com seus termos, todas as outras disposições ou qualquer outra parte remanescente de uma disposição inválida ou inexequível será e continuará sendo válida e exequível em conformidade com seus termos."

Em meio ao negócio jurídico, surgiram algumas pendências entre as partes, até que a empresa constituída para dar fiel cumprimento à parceria, Asia Motors do Brasil S/A (4 ${ }^{\text {a }}$ Requerida), realizou em 2 de março de 1998 assembleia geral extraordinária e nela discutiu um aumento de capital a ser imposto aos acionistas, sobretudo à Asia Motors Company, cabendo a esta a subscrição do valor de U\$ 232.000.000,00.

Conforme dito na exposição inicial, em janeiro de 2000, mais precisamente em 31/1/2000, a Kia Motors Corporation, já sucessora da Asia Motors Company, ingressou com medida cautelar preparatória (Processo n. ${ }^{\circ}$ 140.00.733879-5), distribuída ao Juízo da $23^{\mathrm{a}}$ Cível da Comarca de Salvador, BA, para o fim de sobrestar os efeitos das decisões firmadas na assembleia geral extraordinária realizada em 2/3/1998 pelos acionistas da Asia Motors do Brasil S/A, em que se decidiu pelo aumento de capital desta sociedade, sendo, na sequência, em 29.02.2000, também proposta ação principal com o fim de resguardar os efeitos da liminar concedida e, ainda, tendo como pedido a nulidade da referida assembleia (Processo n. ${ }^{\circ}$ 140007381449). 
Esta ação resultou no REsp. n. ${ }^{\circ}$ 649.711/BA, julgado pela Terceira Turma deste Tribunal em 6 de junho de 2006, cuja decisão definiu a controvérsia e veio a transitar em julgado somente em 7/12/2009.

Tanto na cautelar quanto na principal, a Kia Motors Corporation (Requerente) advertiu para a manutenção da cláusula arbitral, devendo-se colacionar o que restou anotado na ação declaratória, verbis (fl. 1908):

"55. Ressalte-se, V. Exa, que conforme as cláusulas 14.3., 14.4. e 14.5 do Contrato de Joint Venture, que norteia os fatos decorrentes desta ação, as questões emergentes do contrato deverão obrigatoriamente ser submetidas a um Tribunal Arbitral constituído em Nova Iorque, Estados Unidos.

56. Esclarece a Autora, entretanto, conforme já demonstrado nos autos da medida cautelar em apenso, que tendo em vista a natureza urgente da liminar concedida nessa cautelar e por ainda não ter sido constituído referido Tribunal Arbitral, deve a Autora ajuizá-la perante o Poder Judiciário, não implicando, contudo, em renúncia expressa ou tácita de referidas cláusulas de natureza arbitral.

57. Assim sendo, por ora, não resta outra alternativa a Autora senão propor a presente ação principal perante este D. Juízo, a fim de, outrossim, manter-se íntegra a liminar em apreço. Caso, no entanto, posteriormente as partes cheguem a um acordo acerca da instituição de um Juízo Arbitral, as partes irão requerer o que for de direito perante este D. Juízo no que concerne ao prosseguimento desta ação e da respectiva medida cautelar em apenso."

Feita a transcrição acima de partes do contrato de joint venture, bem assim destacado o sentido das ações judiciais propostas pela Requerente, passados mais de quatro anos da existência do negócio jurídico (parceria), isto é, em 24/12/2001, a acionista Kia Motors Corporation ingressou com pedido de procedimento arbitral junto à Câmara de Comércio Internacional - CCI, com fundamento em cláusula compromissória específica, aduzindo um rol de reclamações, suscitando a quebra do contrato e postulando o percebimento de indenizações, fazendo construir a decisão que ora se busca homologar.

A fim de entender o alcance das contestações dos Requeridos, permito-me fazer o seguinte resumo de reclamações apresentadas pela Requerente no Tribunal Arbitral:

\section{Violação do JVA pelos Acionistas brasileiros e AMB.}

Os brasileiros violaram o contrato, como signatários do JVA (joint venture), isso porque:

a) os brasileiros detinham pleno controle da $\mathrm{AMB}$, como resultado de um golpe dado em agosto de 1997 e pelo comportamento dos reclamados, impedindo a Ásia Motors Company (AMC) de exercer o poder que possuía legalmente, o que impunha considerar Infração ao estipulado nas seções 2.3, 2.4 e 4.3 do JVA. 
b) As operações financeiras e manutenção dos registros da AMB foram realizadas exclusivamente pelos brasileiros e por sua equipe financeira, mantendo livros, registros e documentos de suporte da JVA incorretos, incompletos e totalmente inadequado, negando à AMC o direito de inspeção, o que redundou em Infração aos artigos 4.1 e 4.2 do JVA.

c) Os acionistas brasileiros e a $\mathrm{AMB}$ efetuaram transações com terceiros em desconformidades com o disposto no JVA, de sorte a infringir o art. 7 do JVA.

d) Os acionistas brasileiros colocaram em prática um plano de suborno, em detrimento da exigida de boa-fé contratual, para conseguir manter o pagamento dos créditos comerciais denominados D/As, que nunca foram repassados, e para que a AMC ficasse alijada de participar da administração dos negócios, o que gerou desvios de dinheiro e apropriação indevida, Infringindo o art. 14.2 do JVA e causando dano de mais de U\$ 100 milhões em perdas financeiras e uma perda substancial de sua reputação comercial no Brasil.

2. Violação de contrato preliminar ao JVA, denominado de MOU, pelos Requeridos.

3. Nulidade do boletim de subscrição de R $\$ 232$ milhões.

4. O plano de aumento de capital violou o JVA e o Acordo de Acionistas.

5. Violação do Acordo de Cooperação Técnica pela AMB.

$\mathrm{O}$ acordo foi firmado entre a $\mathrm{AMC}$ e a $\mathrm{AMB}$ pelo qual a $\mathrm{AMC}$ forneceu tecnologias à $\mathrm{AMB}$, que deveria pagar US\$ 10 milhões no prazo de 30 dias da sua "data de vigência", que seria a "data da execução deste contrato submetido à condição de obter qualquer e toda aprovação necessária do governo". Alegou, por isso, infração ao art. 1.2 do CTA, porque a AMC forneceu toda a tecnologia requerida mas nunca nada lhe foi pago.

6. Responsabilidade dos reclamados pelos seus atos e omissões.

Os Requeridos agiram através de fraude e coação no aumento de capital e montaram uma companhia para responsabilizar a AMC e a KIA pelo fracasso da Joint Venture, gerando o dever de indenizar a Requerente, inclusive quanto ao repasse dos valores obtidos com as vendas dos veículos importados.

Por sua vez, os Requeridos apresentaram suas respostas, dentre as quais se podem destacar:

1) O Acordo de Acionistas, conquanto não assinado, foi rubricado por todos e fez parte como anexo do JVA.

2) A nova versão dos estatutos, assinada em agosto de 1997, reduziu de 7 para 5 o número dos membros do Conselho de Administração da AMB e cedeu três lugares aos reclamados, que administrou a sociedade de forma normal e buscou impedir as consequências da falência, na Coreia, da AMC, a qual restou 
incorporada pela KIA, sendo o novo estatuto discutido abertamente e reconhecido por todos, exercendo AMC todos o poderes e atos decorrentes do contrato.

3) A não construção da fábrica no Brasil e o fracasso do projeto de parceria foi resultado da situação de falência da $\mathrm{AMC}$, o que fez com que o governo brasileiro não concedesse os incentivos inicialmente previstos, fato que impôs pesados ônus aos Requeridos.

4) $\mathrm{O}$ aumento de capital foi acordado por todos os membros do Conselho da AMB, na Assembléia de 11.2.98, como a única alternativa possível para recuperar a viabilidade do projeto de construção da fábrica e do próprio joint venture.

5) Incompetência do Tribunal de Arbitragem, porque:

a) O JVA não é um contrato abrangente. É um contrato preliminar modificado pelo Acordo de Acionistas e pelo Estatuto Social.

b) $\mathrm{O}$ contrato assinado não é um típico acordo de joint venture, porque um acionista tinha o direito de controlar a empresa. Portanto, o Acordo de Acionistas e o Estatuto não eram contratos satélite condicionados pelo JVA.

c) A cláusula de arbitragem contida no artigo 14.3 do JVA era restrita a conflitos surgidos deste contrato. Por outro lado, o Acordo de Acionistas, exceto pelo que se trata da opção de venda ou compra, contém uma cláusula dando competência aos tribunais da cidade de São Paulo. O estatuto também não está sujeito à competência do tribunal, já que não contém uma cláusula de arbitragem. De qualquer forma, a legislação brasileira não permitia, no momento em que os fatos ocorreram, cláusulas de arbitragem nos estatutos da empresa, o que só foi aceito após a promulgação do art. 109, § 3º da Lei das S/A em 2001.

6) Processos brasileiros: os tribunais brasileiros já decidiram 2 processos em que a KIA não pode recorrer à arbitragem. Houve renúncia de um direito por ela alegado, de recorrer à arbitragem (fls. 737/739).

7) O Tribunal de Arbitragem não possui competência para julgar as reclamações.

8) Salientam que a maneira como a empresa deveria ser administrada e como a AMC recebeu o direito de controlar a empresa é definido detalhadamente no Acordo de Acionistas, que foi rubricado por todos e constou como anexo do JVA, estando as controvérsias daí surgidas sujeitas à Justiça brasileira, consoante previsão da cláusula 7.1 .

9) A responsabilidade pelos créditos comerciais não pagos - os conflitos relacionados aos D/As são excluídos da competência do tribunal. O JVA e sua cláusula de arbitragem não tratavam dos créditos comerciais de D/As, que eram contratos independentes e individuais. Todos os D/As emitidos após a assinatura do MOU e do JVA previam que os conflitos que surjam relacionados a este contrato serão resolvidos mediante arbitragem em Seul. 
10) A nulidade do boletim de subscrição de $R \$ 232$ milhões - questão foi incluída no Acordo de Acionistas e não está sujeita ao tribunal de arbitragem, sendo da competência da justiça comum.

11) O aumento de capital não infringiu o JVA e o acordo mútuo não pode ser submetido à arbitragem.

12) A responsabilidade dos acionistas controladores da AMB, por seus atos e omissões, também não pode ser submetida a arbitragem, porque não prevista cláusula de arbitragem no Acordo de Acionistas, devendo ser as condutas regidas pelo estatuto e pela Lei de Sociedades Anônimas brasileira.

13) A responsabilidade dos reclamados Chong, Washington e Roberto como administradores da AMB - também não podem ser submetida à arbitragem, porque a cláusula de arbitragem do JVA não se aplica a eles como administradores e não assinaram o JVA com a dita capacidade.

Como visto da exposição, tudo quanto possível em torno do negócio jurídico realizado pelas partes foi submetido à Corte Arbitral, que, por sua vez, edificou decisão com 15 itens relativos à reclamação da Requerente; e 3 atinentes às verbas de sucumbências.

A partir do cotejo desses dados, resta averiguar o contexto e o alcance da presente pretensão homologatória, na linha da previsão dos arts. $3^{\circ}, 5^{\circ}$ e $6^{\circ}$ da Resolução n. ${ }^{\circ} 9 / 2005$, que, de forma objetiva, aludem aos seguintes requisitos:

- petição escrita nos moldes do art. 282 do CPC, que deve vir acompanhada da "certidão ou cópia autênticada do texto integral da sentença estrangeira e com outros documentos indispensáveis, devidamente traduzidos e autenticados";

- ter sido proferida a decisão homologanda "por autoridade competente";

- ter havido o trânsito em julgado;

- estar autenticada pelo cônsul brasileiro e acompanhada de tradução por tradutor oficial ou juramentado no Brasil;

- não resultar a homologação pretendida em ofensa à soberania ou à ordem pública nacional.

Então, seriam esses os pontos a abordar de maneira objetiva no juízo de delibação da via proposta.

Introduzo a análise pelo substrato da convenção arbitral e da cláusula compromissória prevista no contrato de joint venture, cumprindo observar, de início, que tenho na convenção o aspecto do compromisso das partes - declaração de vontades - de se submeter ao juízo arbitral, enquanto que a cláusula compromissória é a sua formalização, incluindo a maneira como o Tribunal deve se formar, como as matérias deverão ser suscitadas e quais as normas a serem seguidas para a formação do Juízo decisório no caso concreto. 
A questão conceitual em torno da convenção, no caso, afigura-se importante pela previsão dos arts. $3^{\circ}$ e $4^{\circ}$ da Lei 9.307/1996 (Lei de Arbitragem), a ser observada pela autonomia da vontade das partes que elegeram a lei brasileira para resolver todas as pendências eventualmente propostas.

A propósito, vejam-se as previsões legais aludidas:

"Art. $3^{\circ}$. As partes interessadas podem submeter a solução de seus litígios ao juízo arbitral mediante convenção de arbitragem, assim entendida a cláusula compromissória e o compromisso arbitral."

"Art. $4^{\circ}$. A cláusula compromissória é a convenção através da qual as partes em um contrato comprometem-se a submeter à arbitragem os litígios que possam vir a surgir, relativamente a tal contrato".

E pelo teor dos argumentos lançados pelas partes, tanto no sentido de manter a competência quanto no de negá-la ao Tribunal Arbitral, tudo foi objeto de confronto e exame.

Isso decorre do fato de que, ex vi do acordo de vontades expresso, na espécie, a convenção arbitral se caracterizou pela existência de cláusula compromissória plena, em que foi consentida a formação de um Painel, composto de três árbitros escolhidos por critério pré-estabelecido, na cidade de Nova Iorque, EUA, a ser regido pelas Normas da Câmara Internacional de Comércio - CCI, que deveria examinar, de modo amplo e pela aplicação da lei brasileira, todas as controvérsias surgidas entre as partes.

Reproduza-se, aliás, o teor da cláusula de aplicação de lei e a cláusula compromissória, que representou a convenção arbitral:

"14.1. As partes concordam que este Contrato será regido e interpretado de acordo com as leis da República Federativa do Brasil.

14.3. Qualquer conflito ou reclamação que surja deste Acordo, ou que a ele se relacione, incluindo a interpretação, aplicação e rescisão deste Acordo, e que não possa ser resolvido amigavelmente entre as partes, será resolvido por arbitragem compulsória, em conformidade com as Regras de Conciliação e Arbitragem da Câmara Internacional do Comércio ("ICC").

14.4. O processo de arbitragem ocorrerá na cidade de Nova York, estado de Nova York, Estados Unidos da América ou outra cidade e país e será conduzido na língua inglesa. Os conflitos serão resolvidos por três árbitros. Os Acionistas Brasileiros e a AMC nomearão, cada um, um árbitro. $\mathrm{O}$ Tribunal Arbitral da Câmara Internacional do Comércio nomeará o terceiro árbitro.

14.5. As partes reconhecem que a decisão do árbitro será final e obrigatória com relação a vereditos, sem direito a apelação em nenhum tribunal de nenhuma 
competência. As despesas do árbitro serão divididas igualmente pelas partes, a não ser que o árbitro determine que as despesas sejam calculas de outra forma.

Importante certificar, por oportuno, que a convenção arbitral "é autônoma em relação ao contrato em que estiver inserta, de tal sorte que a nulidade deste não implica, necessariamente, a nulidade da cláusula compromissória", conforme clara previsão do art. $8^{\circ}$ da Lei de Arbitragem acima citada.

Tal é a força da declaração de vontade das partes, que o parágrafo único do referido artigo $8^{\circ}$ transfere aos árbitros a competência para analisar "as questões acerca da existência, validade e eficácia da convenção de arbitragem e do contrato que contenha a cláusula compromissória."

Sobre o debate, e do ponto de vista da validade de transcrita cláusula compromissória, inicio afirmando que na visão do direito interno, sem a menor dúvida não se extrai qualquer contradição na efetiva formulação e existência da convenção arbitral, pois observados os requisitos de constituição do negócio jurídico: agentes capazes, objeto lícito e forma não defesa em lei; além de inexistir qualquer afronta à ordem pública, notadamente pelo fato de expressar a declaração legítima da vontade das partes acerca de contrato plenamente realizável.

Resta saber em que pé estão os argumentos das partes, começando pela contestação ao pedido homologatório.

Quanto a esta, urge realizar breve exposição, conquanto as questões se assemelhem ao que deduzido no foro arbitral.

Capitaneada sobretudo pelo Requerido Washington Armênio Lopes, que apresentou substanciosos argumentos, realizou audiência com esta Relatora e, ainda, apresentou vigorosos memoriais, a negativa ao pleito homologatório qualifica-se nas seguintes teses:

1) Incompetência do tribunal arbitral.

O joint venture (JVA) foi firmado em 24.6.1997 e tinha por objetivo o de regular a relação das partes na empresa que seria por eles criada, a AMB. Continha anexos, uma minuta de acordo de acionistas quase que completa, bem como uma minuta completa do que veio a se tornar o estatuto social da empresa.

Em fevereiro de 1998 foi celebrado outro instrumento, denominado Contrato de Cooperação Técnica para a linha de veículos Topic e Towner, envolvendo apenas a $\mathrm{AMC}$ e a $\mathrm{AMB}$ e cujo fim precípuo era o de transferência de tecnologia à $\mathrm{AMB}$ e que permitisse a essa a construção de uma fábrica de automóveis no Brasil.

Tanto no contrato de JVA como no de Cooperação Técnica havia cláusula compromissória que submetia a resolução de eventuais conflitos à arbitragem.

Entretanto, nas minutas de acordo de acionistas e do estatuto social - que se tornaram definitivos nos exatos termos em que foram minutados na data em que 
assinado o JVA - a vontade dos contratantes foi esboçada de forma diversa, no sentido de não mais eleger a arbitragem como forma de resolução dos conflitos e sim o Poder Judiciário brasileiro, especificamente o foro de São Paulo. O acordo de acionistas previu a solução arbitral para as controvérsias que se relacionassem ao exercício dos direitos dos acionistas tratados no capítulo 4 do acordo e que versa acerca da opção de compra e venda de ações.

Assim, a cláusula compromissória avocada pelo requerente como fundamento da homologação foi revogada pelas partes quando da pactuação do Acordo de Acionistas e do Estatuto.

Além disso, a cláusula compromissória foi revogada na medida em que as partes submeteram o litígio ao Poder Judiciário Brasileiro, mediante a propositura de ação cautelar e declaratória de nulidade das deliberações assembleares tomadas na assembleia de $2 / 3 / 1998$, entre as quais estava o aumento do capital social que foi objeto da arbitragem.

E conclui a parte: portanto, o tribunal arbitral não tinha competência para tratar das questões que estavam sendo submetidas ao conhecimento dos árbitros, eis que as partes expressamente escolheram a justiça brasileira como competente para a resolução dos litígios advindos do acordo de Acionistas e do Estatuto Social.

A matéria foi suscitada no tribunal arbitral como preliminar e rejeitada e agora é novamente suscitada.

2) Falta de citação das empresas American Samoa Corporation e Bambari International S/A no processo de arbitragem.

3) O conflito que gerou a instauração do procedimento arbitral está adstrito ao contrato de JVA e ao acordo de acionistas, não tendo sido discutido o contrato de cooperação técnica na arbitragem, já que se trata da típica discussão entre acionistas e que por sua natureza só poderia estar englobada no próprio contrato de joint venture.

Delimitada, assim, a controvérsia, alega que, uma vez assinado o JVA, seus anexos assumiram vida própria e tornaram-se definitivos, ganhando autonomia nos exatos termos em que foram minutados, passando a reger integralmente o relacionamento entre as partes, superando tudo o que havia sido estipulado no JVA.

Uma vez criada a sociedade prevista no JVA, este foi inteiramente absorvido pelas avenças firmadas de acordo com a legislação societária brasileira e pelo seu estatuto e acordo de acionistas. Trazem parecer de Carlos Alberto Carmona, mencionado durante toda a defesa.

4) O Estatuto Social, em que pese ter incorporado a maioria das previsões do JVA, deixou de englobar a previsão específica de convenção de arbitragem. Dessa forma, os conflitos deveriam ser dirimidos pelo Poder Judiciário. 
5) Já o acordo de acionistas também disciplinou várias questões e estipulou duas regras para a solução dos conflitos: cláusulas 7.1 e 7.3. Assim, a vontade dos contratantes foi a de que a cláusula arbitral ficou restrita às matérias constantes do capítulo 4 do mencionado acordo, que pela sua leitura cuida única e exclusivamente da opção de compra e venda de ações.

Por sua vez, o procedimento arbitral foi instaurado por conta de litígio entre os acionistas decorrente de um aumento de capital e de pretenso abuso de poder de controle por parte dos acionistas brasileiros, o que não se confunde com compra e venda de ações.

Não existe, portanto, cláusula compromissória capaz de fundamentar a presente homologação e que invalida de pleno direito a eficácia da sentença arbitral por incompetência absoluta, o que foi argüido no procedimento arbitral.

6) Revogação da cláusula compromissória - houve revogação implícita, decorrente da prática de ato contraditório e incompatível com a vontade de manter o que havia sido anteriormente acertado, porquanto buscou-se o Judiciário para resolver pendência entre as partes. No caso, a própria recorrente propôs, em janeiro de 2000, medida cautelar perante a $23^{\mathrm{a}}$ vara Cível da Comarca de Salvador, afirmando que a causa de pedir da demanda era o contrato de JVA, mas fez questão de deixar claro que a propositura da cautelar visava apenas a obtenção de tutela de urgência, e que não implicava na renúncia à cláusula arbitral.

Depois, ajuizou ação ordinária, abandonando o que dispunham as cláusulas 14.3, 14.4 e 14.5 do JVA. O litígio, que abarca o mesmo objeto da arbitragem, foi julgado pela Terceira Turma do STJ nos autos do RESP 649.711, em que restou reconhecida a nulidade da mencionada assembleia que deliberou acerca do aumento de capital.

Transitando em julgado a decisão em 7.12.2009, já existiriam os efeitos da coisa julgada material relativa ao aumento de capital objeto da arbitragem, o que redundaria no reconhecimento da revogação da cláusula arbitral.

A exposição dos argumentos da parte fazia-se necessária a fim de responder à contestação.

Assim, analiso a pretensão afastando, por primeiro, a ideia lançada pelo Requerente de que a arguição da incompetência da Corte Arbitral refoge ao exame homologatório, porquanto envolveria o mérito do conflito lá suscitado.

Veja-se que a discussão, na verdade, encontra eco no que preceitua o art. 38, incisos IV e V, da Lei 9.307/96, que prescreve:

"Art. 38. Somente poderá ser negada a homologação para o reconhecimento ou execução de sentença arbitral estrangeira, quando o réu demonstrar que:

$(\ldots)$ 
IV - a sentença arbitral foi proferida fora dos limites da convenção de arbitragem, e não foi possível separar a parte excedente daquela submetida à arbitragem;

V - a instituição da arbitragem não está de acordo com o compromisso arbitral ou cláusula compromissória;"

De notar, com isso, que a questão da competência envolve, na espécie, o exame do alcance da cláusula compromissória, e mais ainda, a própria existência da convenção, temas, aliás, enfrentados pela Corte Arbitral, conforme se nota da exposição acima, sendo matéria a fazer parte deste Juízo como pressuposto da pretensão homologatória, na medida em que se analisa a legitimação do ato sentencial (laudo arbitral) frente ao conteúdo e à extensão da convenção das partes.

O primeiro ponto da alegação de incompetência da Corte Arbitral invoca a revogação da cláusula compromissória pelos acordos subsequentes ao contrato de joint venture.

Tenho que a afirmação não procede, porquanto a caracterização do negócio de parceria denominado de joint venture inicia-se por acordos de intenções, que resulta, depois, no próprio contrato (joint venture), o qual regerá toda a negociação até que realizado o seu objetivo.

Sobre a natureza de tal contrato, Luciano Benetti Timm e Marcelo Borges Rodrigues esclarecem:

"Na prática dos negócios, usualmente a joint venture se inicia através de um acordo de sigilo (confidenciality deed) seguido ou concomitante a um memorando de entendimentos ou protocolo de intenções - traduzi do inglês Memoranda of Understandig. O primeiro servirá para garantir que não haverá vazamento de aspectos importantes da negociação, nem dados sigilosos de nenhuma empresa envolvida no negócio.

Já o segundo terá uma função variada, envolvendo, entre outras desde o estabelecimento de um plano ou roteiro de negociação, passando por eventuais pontos de concordância ou de divergência entre as partes e servindo até mesmo para estabelecer a lei aplicável e foro de eleição para casos de eventuais disputas surgidas nessa fase das tratativas (...).

O passo seguinte é a celebração do "contrato base" ou "contrato mãe" ou "contrato guarda chuva" de joint venture, que é já um negócio jurídico definitivo, ao contrário do memorando de entendimentos. Aquele contrato definitivo da joint venture servirá como uma espécie de "carta magna" que inclui os pontos essenciais e norteará os eventuais futuros "acordos satélites" ou "acordos filhotes".

As cláusulas mais relevantes desse contrato guarda-chuva, entre outras, dizem respeito aos objetivos das partes e ao escopo do negócio por elas entabulado; às obrigações que cada uma das partes assumirá com vistas ao sucesso do empreendimento comum; aos investimentos de cada uma das partes e à forma da 
divisão dos resultados positivos e negativos; compartilhamento e alocação de responsabilidades e riscos; forma de gestão e de divisão do poder de controle do negócio; formato legal a ser adotado pelas partes (criação de uma nova sociedade ou não); lei e forma de solução de controvérsias." (Os conflitos nas joint ventures e a arbitragem - Premissas conceituais: elementos essenciais das joint ventures. Revista de Arbitragem e Mediação Ano 6-21, pág. 67, 2009).

$\mathrm{O}$ caso não fugiu à regra da proposta de joint venture, devendo-se destacar a autonomia da vontade das partes que, de fato, propuseram e aceitaram negócio dessa natureza.

Aqui vale recobrar, haja vista a cláusula de eleição do direito pátrio, regra segundo a qual, em contrato, deve-se dar maior prevalência ao sentido do avençado e não ao que eventualmente vem a ser escrito (art. 112 do CCB).

Sem querer adentrar no âmago da contratação, cuja análise refoge ao procedimento de homologação, a questão deve ser definida pelo propósito das partes, no caso, averiguável para o fim de solver a proposição do primeiro Requerido, por meio da constatação do inequívoco propósito de edificar, com o contrato principal de joint venture, a convenção arbitral através da cláusula compromissória 14.3/14.4, passando tudo a partir dali a ser tributário desse pacto.

A despeito de considerar o contrato de joint venture como a célula mãe de todos os outros, afinal, não seria crível pressupor que os contratantes, diante de negócio tão complexo e valioso, indiscutivelmente, representados por especialistas, assumissem uma proposta de convenção arbitral cheia, no sentido de prever alargada competência do Juízo Arbitral, e, logo em seguida, a revogassem sem a mínima referência ao referido pacto.

Ademais, nessa espécie de pactuação, já se tem dito que uma vez formalizada, inequivocamente, a submissão a Juízo Arbitral somente convenção em igual teor pode desconstituir a força da convenção, a não ser que se demonstre concretamente haver a parte, ou partes, dela se afastado; o que não me parecer ser a hipótese em análise, que cuida de joint venture perfeitamente enquadrável.

Basta notar que houve a previsão de uma parceria entre empresas, as quais mantiveram suas personalidades jurídicas, em que uma deveria transferir tecnologia e produtos de marca a outra, que, por sua vez, se obrigava a cumprir certos compromissos com vistas a garantir a venda dos bens transferidos pela contratante.

Aponto, ainda, que esta Corte já creditou especial atenção para casos em que não houve a expressa aceitação da convenção arbitral, impedindo, por essa razão, a pretensão homologatória em que não se verificou a vontade expressa.

Para consulta, vejam-se os precedentes:

"PROCESSUAL CIVIL. SEC - SENTENÇA ESTRANGEIRA CONTESTADA. 
HOMOLOGAÇÃO. DESCABIMENTO. ELEIÇÃO DO JUÍZO ARBITRAL. AUSÊNCIA DE MANIFESTAÇÃO EXPRESSA DA PARTE REQUERIDA. OFENSA A PRINCÍPIO DE ORDEM PÚBLICA. INDEFERIMENTO DO PEDIDO DE HOMOLOGAÇÃO.

1. PLEXUS COTTON LIMITED, sociedade constituída e existente de acordo com as leis da Inglaterra, com sede em Liverpool, Inglaterra, requer a homologação de SENTENÇA ARBITRAL ESTRANGEIRA, proferida por LIVERPOOL COTTON ASSOCIATION - LCA, que condenou SANTANA TÊXTIL LTDA. a pagar à requerente a quantia de U\$D 231.776,35 (duzentos e trinta e um mil, setecentos e setenta e seis dólares e trinta e cinco centavos), além de determinar o faturamento de parte da mercadoria ou o equivalente a 2.204.600 libras líquidas, em razão de descumprimento de contrato firmado entre as partes.

2. Na hipótese em exame, consoante o registrado nos autos, não restou caracterizada a manifestação ou a vontade da requerida no tocante à eleição do Juízo arbitral, uma vez que não consta a sua assinatura nos contratos nos quais se estabeleceu a cláusula arbitral.

3. A inequívoca demonstração da manifestação de vontade de a parte aderir e constituir o Juízo arbitral ofende à ordem pública, porquanto afronta princípio insculpido em nosso ordenamento jurídico, que exige aceitação expressa das partes por submeterem a solução dos conflitos surgidos nos negócios jurídicos contratuais privados arbitragem.

4. No caso em exame, não houve manifestação expressa da requerida quanto à eleição do Juízo Arbitral, o que impede a utilização desta via jurisdicional na presente controvérsia.

5. Pedido de homologação a que se nega deferimento." (SEC 967/GB, Rel. Ministro JOSÉ DELGADO, CORTE ESPECIAL, julgado em 15/02/2006, DJ 2003/2006, p. 175)

"SENTENÇA ARBITRAL ESTRANGEIRA. HOMOLOGAÇÃO. CLÁUSULA COMPROMISSÓRIA.

AUSÊNCIA DE ASSINATURA. OFENSA À ORDEM PÚBLICA. PRECEDENTES DO SUPERIOR TRIBUNAL DE JUSTIÇA E DO SUPREMO TRIBUNAL FEDERAL.

1. "A inequívoca demonstração da manifestação de vontade de a parte aderir e constituir o Juízo arbitral ofende à ordem pública, porquanto afronta princípio insculpido em nosso ordenamento jurídico, que exige aceitação expressa das partes por submeterem a solução dos conflitos surgidos nos negócios jurídicos contratuais privados arbitragem." (SEC n 967/GB, Relator Ministro José Delgado, in DJ 20/3/2006).

2. A falta de assinatura na cláusula de eleição do juízo arbitral contida no contrato de compra e venda, no seu termo aditivo e na indicação de árbitro em nome da requerida exclui a pretensão homologatória, enquanto ofende 0 artigo $4^{\circ}$, 
parágrafo $2^{\circ}$, da Lei $\mathrm{n}^{\circ} 9.307 / 96$, o princípio da autonomia da vontade e a ordem pública brasileira.

3. Pedido de homologação de sentença arbitral estrangeira indeferido." (SEC .978/GB, Rel. Ministro HAMILTON CARVALHIDO, CORTE ESPECIAL, julgado em 17/12/2008, DJe 0503/2009)

Dentro desse entendimento, por óbvio, uma vez constatada a vontade expressa das partes não se pode dela afastar por mera suposição, ainda mais quando claramente identificados os propósitos dos contratantes.

Por isso que importante interpretar a vontade expressa das partes, in casu, a partir da proposta inicial contida no contrato "mãe", que dispunha que eventuais controvérsias seriam submetidas à resolução arbitral, sendo a proposição somente superada se acaso existente termo equivalente.

Cabe aqui transcrever a cláusula 1.1. do joint venture que rezava:

"1.1 O objetivo deste Acordo é fornecer as normas que regulamentarão a relação das partes na empresa, que será financiada, operada e administrada de acordo com os termos e condições estabelecidos neste Acordo, no Estatuto da EMPRESA e no Acordo de Acionistas."

E por falar em interpretação, por oportuno, consigne-se que a cláusula 14.3. do contrato principal não deixa dúvida de sua extensão:

"Qualquer conflito ou reclamação que surja deste Acordo, ou que a ele se relacione, incluindo a interpretação, aplicação e rescisão deste, e que não possa ser resolvido amigavelmente entre as partes, será resolvido por arbitragem compulsória, em conformidade com as Regras de Conciliação e Arbitragem da Câmara Internacional do Comércio ("ICC")."

Assim, o fato de se prever, em acordo de acionistas subsequente, menor extensão da convenção, ou mesmo de não constar de avença posterior previsão semelhante, não poderia revogar ou tornar sem efeito a cláusula compromissória expressamente querida e aceita pelas partes no contrato padrão, que em qualquer caso deve prevalecer, à exceção de expressa redefinição.

Na mesma medida da mencionada cláusula 14.3, considera-se a existência de uma convenção bastante abrangente, no sentido de firmar a competência do Juízo Arbitral para "qualquer conflito ou reclamação".

Dessa maneira, a extensão dos poderes dos árbitros não se conformava somente ao acordo de acionistas, mas também a outras convenções porventura surgidas do objeto da joint venture.

É preciso notar que a cláusula 7.3. do acordo anexo (acordo de acionistas) faz menção a capítulo específico de suas estipulações mais como forma de reforçar a convenção arbitral naquela oportunidade, e sobre o tema específico, e não propriamente com o objetivo de substituir a intenção inicial das partes, não se 
podendo supor que havia ali restrição ou ainda que estava, a referida cláusula, a modificar aqueloutra do contrato principal (cláusula 14.3).

Inexiste, por isso, a ocorrência de julgamento extra petita por parte da Corte Arbitral, tampouco se pode constatar, pela mesma razão, a incompetência deduzida pela contestação do primeiro Requerido.

O terceiro ponto da contestação sugere a renúncia da Requerente ao Juízo Arbitral por conta do ajuizamento de ações na Justiça Comum brasileira, as quais se originaram do contexto do contrato de parceria, especialmente as que tiveram trâmite na Justiça Comum da Bahia.

$\mathrm{O}$ ponto tem de ser visto sob dois ângulos. O primeiro diz respeito a considerar a renúncia como ato manifesto da parte; enquanto que o segundo reclama a possibilidade da convivência concorrente dos juízos possíveis de resolução da lide: o judicial e o arbitral.

No tocante ao prisma primeiramente posto, acerca do ato de renúncia, antes de mais nada, consigne-se que a própria cláusula arbitral surge da renúncia recíproca dos contratantes, que ancorados na garantia fundamental do direito à liberdade de dispor de direitos patrimoniais, transferem a juízo que não decorrente do Judiciário o poder de dizer do direito envolvido. Renunciaram, unilateralmente, a um direito, qual seja, à conquista revolucionária da jurisdição estatal e estatuíram, de forma bilateral, um vínculo, que se denomina de cláusula arbitral.

À medida em que surge a controvérsia entre as partes, seria correto imaginar nova renúncia, pura e simples, mesmo que tácita, sem a explicitação concreta da perda de um direito específico e ainda sem a participação da parte contrária?

Parece não ser cogitável a proposição pelo simples fato de perceber que a utilização da via judicial, no caso vertente, sobreveio com expressa menção de não-renúncia e, também, porque, dentro do plano da existência da bilateralidade da convenção arbitral, a outra parte não questionou o sentido da exceção no momento oportuno.

Isto quer dizer: os Requeridos não advertiram, quando do ajuizamento das ações judiciais precedentes, para a descaracterização da cláusula arbitral ou postularam eventual declaração de renúncia, fazendo apenas quando constituído o procedimento arbitral.

A situação conclama averiguar o segundo ângulo acima delineado, no sentido de reconhecer eventual concorrência de jurisdições, conforme mesmo advertiu a Corte Arbitral.

Neste momento, recorde-se da regra do art. 90 do CPC, segundo a qual "A ação intentada perante tribunal estrangeiro não induz litispendência, nem obsta a que a autoridade judiciária brasileira conheça da mesma causa e das que Ihe são conexas". 
Conjugado esta regra com o que vem previsto no art. 267, VII, do mesmo Diploma Legal, verifica-se que a questão deve ser suscitada como pressuposto do processo, já que inexistente a litispendência internacional.

Essa perspectiva, por sinal, pode ser corroborada pelo entendimento da Suprema Corte em casos parecidos, tal qual fomentado no julgamento da SEC n. ${ }^{\circ} 7209$, que abordou a existência de processo em curso no Brasil diante de decisão proferida em processo no exterior.

Confira-se o sumário da decisão, no que interessa:

"SENTENÇA ESTRANGEIRA - TRAMITAÇÃO DE PROCESSO NO BRASIL - HOMOLOGAÇÃO. O fato de ter-se, no Brasil, o curso de processo concernente a conflito de interesses dirimido em sentença estrangeira transitada em julgado não é óbice à homologação desta última. (...)."(SEC 7209, Relator(a): Min. ELLEN GRACIE, Relator(a) p $\mathrm{d}$ Acórdão: Min. MARCO AURÉLIO, Tribunal Pleno, julgado em 3009/2004, DJ 29-09-2006 PP-00036 EMENT VOL-02249-04 PP-00659 LEXSTF v. 28, n. 336, 2006, p. 265-282)

À vista dessa posição jurisprudencial, e do quanto vem preconizando a doutrina especializada, afigura-se correto ampliá-la para os casos de concorrência entre a jurisdição estatal e a "jurisdição" arbitral.

Isso porque, a decisão arbitral, no âmbito do direito interno restou recepcionada na mesma sede de coercitividade das decisões judiciais.

Estar-se a delimitar, portanto, a possibilidade de haver a discussão no âmbito da Justiça Interna e no âmbito do procedimento arbitral, devendo a parte interessada suscitar, no momento próprio, os impedimentos à constituição válida do processo e da ação.

Retomando a questão dos autos, o simples ajuizamento de ação cautelar, da qual se seguiu a ação principal, acerca de controvérsia a ser verificada no âmbito do procedimento arbitral, por força da convenção que o previa, não impõe considerar, de per si, ter havido renúncia, fato que também não torna o Juízo Arbitral incompetente para tratar dos temas perante ele veiculados, sobretudo com relação aos que não colidiam com o objeto da ação judicial.

E isso pode ser confirmado pela interpretação do $\S 4^{\circ}$ do art. 22 da Lei 9.307/96, bem assim dos $\S \S 2^{\circ}$ e $3^{\circ}$ do artigo $4^{\circ}$ da Resolução n. ${ }^{\circ}$ 9/2005, que assim preceituam, respectivamente:

" $4^{\circ}$ Ressalvado o disposto no $\S 2^{\circ}$, havendo necessidade de medidas coercitivas ou cautelares, os árbitros poderão solicitá-las ao órgão do Poder Judiciário que seria, originariamente, competente para julgar a causa."

"§ $2^{\circ}$ As decisões estrangeiras podem ser homologadas parcialmente.

$\S 3^{\text {o }}$ Admite-se tutela de urgência nos procedimentos de homologação de sentenças estrangeiras." 
Se a intenção das normas é a de tornar eficazes as decisões que resolvem as demandas propostas pelos jurisdicionados, quer sejam elas decorrentes do Juízo Estatal ou do Juízo Arbitral, a concorrência de "jurisdições" muitas vezes é complementar e saudável, porque preserva a efetividade das decisões.

E isso não afasta a análise da questão pela vertente da eficácia da decisão arbitral frente à eventual coisa julgada oriunda da decisão proferida por Juiz nacional, o qual será logo averiguado.

Assim é que não acolho a tese de comprometimento da via arbitral ante a existência de ações judiciais, ainda mais quando a parte esclarece quanto à necessidade da proposição preliminar e quanto à excepcionalidade da ação de conhecimento; cujos parâmetros de validade não podem ser aqui verificados em razão de não fazer parte de item do decisum homologando.

Tem-se, por ora, a discussão sobre a alegada falta de citação das empresas American Samoa Corporation e Bambari International S/A para o processo de arbitragem.

Sobre a questão, pareceram-me absolutamente intransponíveis os argumentos do Ilustre representante do Ministério Público Federal que assim afasta a alegação (fl. 1856):

"Com relação à suposta ausência de citação, oportuno ressaltar que a sentença homologanda dispõe às fls. 411 (tradução fls. 593) que as empresas em questão, American Samoa e Bambari, foram revéis durante todo o procedimento arbitral. Com efeito, a sentença homologanda dispõe que: "Respondents nr. 7 and 8 have defaulted throughout the arbitration". Cabe destacar que, apesar de tal afirmação ter sido traduzida como "Reclamados $n^{\circ}$ s. 7 e 8 cometeram omissões durante todo o processo de arbitragem", na verdade, o que verificou-se foi a revelia, pois, apesar de regularmente citadas as empresas, estas não compareceram: "Have defaulted". Ademais, o requerente anexou aos autos documentação comprobatória (fls. 1766 e 1772) da ciência das empresas com relação ao procedimento arbitral, sem contudo se fazerem representar. Logo, constatada a revelia pelo tribunal arbitral, um dos requisitos exigidos pelo art. $5^{\circ}$ da Resolução n. ${ }^{\circ}$, do STJ foi cumprido."

Como dito pelo Ilustre parecerista, a verificação da revelia retira a hipótese de falta de citação, porque aquela só é verificável após a concretização desta.

Ao ensejo, advirta-se para a impossibilidade de constatar-se, pela ótica do primeiro Requerido, a validade e a configuração da revelia, já que as partes propuseram o procedimento de "arbitragem compulsória, em conformidade com as Regras de Conciliação e Arbitragem da Câmara Internacional de Comércio ("ICC")."

E ao que tudo indica, consoante termo assinado pelas empresas em questão, o qual encontra-se encartado à fl. 1772, houve, sim, a devida comunicação do procedimento arbitral, não o respondendo as referidas reclamadas porque entenderam ocorrer a incompetência da Corte Arbitral para julgá-las. 
Advirta-se, também, que incumbe à parte requerida o ônus de comprovar induvidosamente o vício da citação, conforme entendimento deste Tribunal. Confiram-se:

"SENTENÇA ESTRANGEIRA. JUÍZO ARBITRAL. CONTRATO INTERNACIONAL FIRMADO COM CLÁUSULA ARBITRAL. CONTRATO INADIMPLIDO. LEI 9.307/96 (LEI DE ARBITRAGEM), ARTS. 38, III E 39, PARÁGRAFO ÚNICO. SENTENÇA HOMOLOGADA.

1. Contrato internacional de fornecimento de algodão firmado entre agricultor brasileiro e empresa francesa, com cláusula arbitral expressa. Procedimento arbitral instaurado ante o inadimplemento do contrato pela parte brasileira.

2. Nos termos do art. 39, parágrafo único, da Lei de Arbitragem, é descabida a alegação, in casu, de necessidade de citação por meio de carta rogatória ou de ausência de citação, ante a comprovação de que o requerido foi comunicado acerca do início do procedimento de arbitragem, bem como dos atos ali realizados, tanto por meio das empresas de serviços de courier, como também via correio eletrônico e fax.

3. O requerido não se desincumbiu do ônus constante no art. 38, III, da mesma lei, qual seja, a comprovação de que não fora notificado do procedimento de arbitragem ou que tenha sido violado o princípio do contraditório, impossibilitando sua ampla defesa.

4. Doutrina e precedentes da Corte Especial.

5. Sentença arbitral homologada." (SEC 3.660/GB, Rel. Ministro ARNALDO ESTEVES LIMA, CORTE ESPECIAL, julgado em 2805/2009, DJe 25/06/2009)

"HOMOLOGAÇÃO DE SENTENÇA ESTRANGEIRA. SENTENÇA ARBITRAL. PROCEDIMENTO ARBITRAL QUE TEVE CURSO À REVELIA DO REQUERIDO. CONVENÇÃO ARBITRAL.

\section{INEXISTÊNCIA.}

1. Para a homologação de sentença de arbitragem estrangeira proferida à revelia do requerido, deve ele, por ser seu o ônus, comprovar, nos termos do inciso III do art. 38 da Lei n. 9.307/96, que não foi devidamente comunicado da instauração do procedimento arbitral.

2. Homologação deferida." (SEC 887/FR, Rel. Ministro JOÃO OTÁVIO DE NORONHA, CORTE ESPECIAL, julgado em 0603/2006, DJ 03/04/2006, p. 196)

Neste momento, é de se ponderar quanto à procedência parcial do pedido homologatório, tendo em vista nova postulação da Requerente na qual dispensa a pretensão em torno dos itens 7 e 10 da sentença arbitral, que dispõem:

"7. O Tribunal Arbitral declara que o boletim de subscrição no valor de R \$ 232.310.204,00, datado de 2 de marco de 1998, o qual os Reclamados alegam 
obrigar a Reclamante a efetuar um aporte de capital no valor de R\$ 232.310.204,00 para a AMB fica nulo e sem efeito, uma vez que a AMC carecia da capacidade legal para incorrer na obrigação e ainda de acordo com o artigo 147 (II) do Codigo Civil Brasileiro de 1916, porque ocorrera devido a ilegitimidade resultante de erro, fraude, coerção e simulação. Em consequência, o painel Arbitral declara que a AMC não tem qualquer obrigação de efetuar o pagamento citado de $\mathrm{R} \$ 232.310 .204,00$ referente ao boletim de subscrição.

10. O Tribunal Arbitral declara que a Set permanece obrigada a cumprir a totalidade da subscrição do aumento de capital da AMB, no valor de R\$ 223.200.000.00."

Nesta passagem, reafirme-se a controvérsia em torno da coisa julgada, já que a decisão firmada pela Justiça brasileira, no âmbito da ação declaratória de nulidade proposta no Juízo da $23^{\text {a }}$ Vara Cível da Comarca de Salvador, BA (Processo n. ${ }^{\circ}$ 140.00.733879-5) e proferida em Recurso Especial (REsp. n. ${ }^{\circ}$ 649.711/BA), transitou em julgado em 7/12/2009, devendo prevalecer em detrimento dos referidos itens da decisão arbitral que se mostram equivalentes, já que em ambos os casos foi a assembleia de subscrição de aumento de capital anulada, conforme se comprava da conclusão do voto-vencedor proferido no acórdão desta Corte, verbis:

"...se o procurador não poderia praticar nenhum ato relativo à assembléia, porque presente nulidade de pleno direito, diante de dispositivo legal específico, também a assembléia está marcada por vício insanável, porquanto o Senhor Lee não podia nela representar a sociedade autora.

Tenha-se presente que essa circunstância, sob todas as luzes, macula a assembléia geral extraordinária considerando que a acionista autora da ação não estava presente, alcançando as deliberações nela tomadas com a participação do Senhor Jong Kun Lee, sendo desnecessário manejar fundamentação maior sobre se nula ou inexistente.

(...) conheço do especial e lhe dou provimento para declarar a nulidade das deliberações aprovadas na assembléia geral extraordinária, objeto da presente ação, com a participação do Senhor Jong Kun Lee, julgando procedente a ação ordinária e a cautelar. Custas de ambas as ações e honorários de R $\$ 100.000,00$ para cada ação, pela parte vencida." (trecho do voto do eminente e saudoso Ministro Menezes Direito, proferido no aludido recurso especial)

Aqui é de se observar que a existência de decisão anterior à homologação, de Juízo nacional, tem prevalência sobre a decisão arbitral não homologada, porque acobertada pelo manto da coisa julgada.

Com efeito, se o propósito da via homologatória é internalizar os efeitos da decisão proferida no estrangeiro, não se afigura lógico persistir a pretensão quanto aos temas abrangidos por decisão da Justiça brasileira. 
Por esse motivo é que se apresenta adequado proceder ao decote da sentença homologanda dos temas que conflitam com a res iudicata.

Por fim, com a finalidade de se evitar interpretações precipitadas, apresenta-se essencial destacar e repisar parte do ambiente da decisão que se objetiva homologar no tocante ao deliberado no seu item 1, que frustrou a pretensão da Requerente em relação à subscrição inicial, de $51 \%$ das ações da empresa constituída com a joint venture.

Considerou a Corte Arbitral, nos termos lançados às fls. 843/889, acerca desse ponto, que a discussão sobre o fechamento efetivo da parceria com a respectiva subscrição das ações da $\mathrm{AMB}$, em que a Asia Motors Company passou a deter, em tese, o controle acionário da sociedade, estava alcançada pela prescrição, consoante dispunha o art. 147 do Código Civil1916.

Além disso, consignou o princípio de que "um acionista com $51 \%$ é o acionista majoritário e se ele decidir não usar seu poder e deixá-lo com outro acionista, este é que deve exercer este poder em nome ou representação do acionista majoritário" e concluiu que a Asia Motors (reclamante) "nunca decidiu abandonar a AMB" - fl. 889, situação a impedir o desejo da ora Requerente de ser excluída, desde o início, do quadro societário.

De se inferir, portanto, que a decisão homologanda deixou claro que não estava a eximir a Requerente das obrigações advindas do negócio jurídico legalmente pactuado, e enquanto partícipe da administração societária, das imposições legais, incluindo-se aí, obviamente, sujeições tributárias e outras a serem verificadas em espaço próprio e em foro competente do Judiciário brasileiro. Ou seja: a requerente mantém-se vinculada às obrigações tributárias assumidas com a atividade da empresa denominada Asia Motors do Brasil S/A - AMB, em cuja participação detinha o controle acionário, controle esse mantido e não anulado pela decisão arbitral.

Entender o contrário, aliás, esvaziaria a defesa da requerente no sentido de sustentar a vigência do contrato de joint venture e suas consequências em desfavor do Reclamados, que ora se procura sedimentar em território pátrio.

Ante o exposto, defiro parcialmente o pedido de homologação da sentença proferida pela Corte Arbitral examinada nesta oportunidade.

Custas e honorários, estes fixados em $\mathrm{R} \$ 2.000,00$, a cargo dos Requeridos, à exceção do Requerido Roberto Uchoa Neto.

É como voto. 


\section{CERTIDÃO DE JULGAMENTO}

CORTE ESPECIAL

Número Registro: 2007/0156979-5

SEC 1/KR

Número Origem: 200500003685

PAUTA: $2804 / 2011$

JULGADO: 2804/2011

\section{Relatora}

Exma. Sra. Ministra MARIA THEREZA DE ASSIS MOURA

Presidente da Sessão

Exmo. Sr. Ministro ARI PARGENDLER

Subprocurador-Geral da República

Exmo. Sr. Dr. BRASILINO PEREIRA DOS SANTOS

Secretária

Bela. VANIA MARIA SOARES ROCHA

AUTUAÇÃO

REQUERENTE : KIA MOTORS CORPORATION

ADVOGADO : EVANDRO LUÍS CASTELLO BRANCO PERTENCE E OUTRO(S)

REQUERIDO : WASHINGTON ARMÊNIO LOPES

ADVOGADO : ARNOLDO WALD FILHO E OUTRO(S)

REQUERIDO : CHONG JIN JEON

ADVOGADO : DEFENSORIA PÚBLICA DA UNIÂO - CURADOR ESPECIAL

REQUERIDO : ROBERTO UCHÔA NETO

ADVOGADO : LUIZ ROBERTO DE ANDRADE NOVAES E OUTRO(S)

REQUERIDO : ÁSIA MOTORS DO BRASIL S/A

REQUERIDO : SET PARTICIPAÇÕES E EMPREENDIMENTOS S/A

ADVOGADO : DEFENSORIA PÚBLICA DA UNIÂO - CURADOR ESPECIAL

REQUERIDO : SET TRADING S/A

ADVOGADO : DEFENSORIA PÚBLICA DA UNIÃO - CURADOR ESPECIAL

REQUERIDO : JBP DO BRASIL

ADVOGADA : TEREZINHA ANICETO CAMERON

REQUERIDO : AMERICAN SAMOA CORPORATION

ADVOGADO : DEFENSORIA PÚBLICA DA UNIÃO - CURADOR ESPECIAL

ASSUNTO: Civil - Juizo Arbitral

\section{SUSTENTAÇÃO ORAL}

Sustentaram oralmente o Dr. Sérgio Bermudes, pela requerente, e o Dr. Marcus Vinicius Vita Ferreira, pelo requerido Washington Armênio Lopes. 


\section{CERTIDÃO}

Certifico que a egrégia CORTE ESPECIAL, ao apreciar o processo em epígrafe na sessão realizada nesta data, proferiu a seguinte decisão:

Após o voto da Sra. Ministra Relatora deferindo em parte o pedido de homologação, no que foi acompanhada pelo Sr. Ministro Mauro Campbell Marques, pediu vista antecipadamente o Sr. Ministro Francisco Falcão.

Aguardam os Srs. Ministros Raul Araújo, Paulo de Tarso Sanseverino, Cesar Asfor Rocha, Gilson Dipp, Hamilton Carvalhido, Nancy Andrighi, Laurita Vaz, João Otávio de Noronha, Massami Uyeda e Humberto Martins.

Ausentes, justificadamente, o Sr. Ministro Teori Albino Zavascki e, ocasionalmente, os Srs. Ministros Felix Fischer, Eliana Calmon, Castro Meira e Arnaldo Esteves Lima.

Convocados os Srs. Ministros Mauro Campbell Marques, Raul Araújo e Paulo de Tarso Sanseverino para compor quórum

\section{SENTENÇA ESTRANGEIRA CONTESTADA No 1 - KR (2007/0156979-5)} (f)

\section{VOTO-VISTA}

\section{O EXMO. SR. MINISTRO FRANCISCO FALCÃO:}

Cuida-se de pedido de homologação de sentença arbitral estrangeira proferida pelo Tribunal Arbitral de Nova Iorque, requerido por Kia Motors Corporation, em substituição à Asia Motors Company (AMC), que por aquela foi incorporada.

O processo é da Relatoria da em. Ministra Maria Thereza, que o trouxe a julgamento na assentada de 4 de maio último. Para melhor compreensão da controvérsia, pedi vista antecipada dos autos, após o voto da Sra. Ministra Relatora deferindo em parte o pedido de homologação, no que foi acompanhada pelo Sr. Ministro Mauro Campbell Marques.

Numa breve rememoração do caso, a questio iuris decidida pelo juízo arbitral - e que ora se visa homologar - diz respeito a negócio jurídico celebrado entre a AMC e a Asia Motors do Brasil (AMB), tendo esta última sido condenada ao pagamento de US\$ 79.058.751,00 correspondentes a créditos pendentes de pagamento e devidos à $\mathrm{AMC}$. Isto porque, segundo a decisão arbitral, a AMB teria violado diversos artigos do contrato firmado, dando ensejo, inclusive, à rescisão contratual, conforme declarada, pelo próprio juízo arbitral.

Ainda, consta da decisão arbitral a declaração de que a AMB, Washington Armênio Lopes, Chong Jin Jeon, a Set, a JBP, a Bambari e a American Samoa todos Requeridos no âmbito desta SEC - são responsáveis, solidária e isoladamente, pela obrigação de indenizar a AMC por todos os danos e perdas que sofreu em consequência do aumento de capital fraudulento da AMB, datado de 
março de 1998, inclusive por todos os valores que a AMC tenha sido obrigada a pagar resultantes de sua subscrição do boletim de subscrição datado de 2 de marco de 1998, no valor de $\mathrm{R} \$ 232.310,204,00$.

Por fim, declarou-se que Washington Armênio Lopes e Chong Jin Jeon sempre foram os Acionistas Controladores da AMB, de acordo com o artigo 116 da Lei das Sociedades Anônimas e que, naquela capacidade, violaram seus deveres legais em relação à $\mathrm{AMB}$ e seus acionistas e que, como consequência, terão de indenizar a AMC pelas perdas e danos sofridos e a sofrer em resultado daquelas violações.

Roberto Uchôa Neto, que também consta como Requerido nesta SEC, foi declarado não culpado por qualquer conduta ilegítima, nada devendo à AMC, segundo a decisão arbitral, seja na qualidade de acionista ou de administrador da AMB.

A Requerente (Asia Motors Company - AMC), em breve resumo, sustenta estarem presentes os requisitos para a homologação da decisão estrangeira.

O Requerido Washington Armênio Lopes alega a incompetência do Tribunal Arbitral porquanto: (a) a cláusula compromissória, instituída no contrato de joint venture teria sido superada por deliberações posteriores, em especial o acordo de acionistas e o contrato social, que, assinados logo depois do contrato inicial, não previram a convenção arbitral, como bem relevou a em. Ministra Maria Tereza; (b) as questões submetidas ao Tribunal Arbitral não estariam abarcadas pela cláusula compromissória; (c) teria havido a revogação tácita da convenção arbitral, haja vista que a Requerente AMC ajuizou ações perante a Justiça Brasileira, envolvendo os negócios jurídicos

Outrossim, sustenta o Requerido Washington Armênio Lopes não terem as empresas American Samoa Corporation e Bambari International S/A sido citadas no processo de arbitragem.

Chong Jin Jeon, Ásia Motors do Brasil S/A, Set Participações e Empreendimentos S/A, Set Trading e America Samoa, representados pela Defensoria Pública da União, pedem, genericamente, seja denegada a homologação da decisão arbitral.

A JBP do Brasil, por sua vez, não contraditou o requerimento de homologação e o Requerido Roberto Uchôa manifestou a sua concordância quanto à homologação.

O Ministério Público Federal opinou pela homologação parcial do pedido, tendo em vista que os itens 7 e 10 da decisão arbitral conflitaria com o que decidido por esta Colenda Corte no REsp n. 649711/BA, relativamente a ação ajuizada pela a AMC perante a Justiça da Bahia.

A il. Ministra Maria Thereza, na esteira do parecer ministerial, apresentou voto pela homologação parcial do pedido, à consideração de que presentes os pressupostos elencados na Resolução $n^{\circ}$ 9/STJ - 2005, com a ressalva de que $a$ existência de decisão anterior à homologação, de Juízo nacional, tem prevalência sobre a decisão arbitral não homologada, porque acobertada pelo manto da 
coisa julgada, de modo que seria adequado, em suas palavras, se proceder ao decote da sentença homologanda dos temas que conflitam com a res iudicata.

De fato, a legitimidade da Requerente para apresentar o pedido homologatório de que se cuida encontra-se evidenciada; a competência da Corte Arbitral de Nova Iorque para o proferimento da decisão sob exame é manifesta, não cabendo, nesta via, discussão de mérito acerca da suposta absorção do contrato joint venture pelo Estatuto social e Acordo de Acionista, como bem realçou o parecer ministerial (fls. 1857); todos os Requeridos foram devidamente citados, segundo amplamente comprovado (fls. 593); o trânsito em julgado da decisão encontra-se atestado às fls. 1020, tendo em vista não ser ela passível de recurso. Por fim, a decisão encontra-se traduzida, por tradutora juramentada no Brasil, motivo por que presentes os requisitos mencionados na Resolução n. 9/STJ, de 4/5/2005, como indispensáveis à homologação de sentença estrangeira.

Demais disso, convém relevar que a negativa da homologação pretendida somente seria possível se houvesse qualquer problema relativo à autenticidade dos documentos apresentados, à inteligência da decisão ou aos requisitos formais constantes da Resolução n. 9/STJ - 2005, o que não é o caso.

Excetuam-se, contudo, os itens 7 e 10 da sentença homologanda, que tratam da nulidade da assembléia de acionistas, tema este julgado pela Justiça Brasileira, por sentença transitada em julgado. Neste particular, a homologação da decisão arbitral traria clara ofensa aos princípios da soberania nacional, na medida em que se estaria dando prevalência a uma decisão estrangeira sobre decisão judicial brasileira, ainda mais com trânsito em julgado.

Estas as considerações, acompanho o excelente voto proferido pela em. Ministra Relatora, inclusive quanto ao esclarecimento que prestou com relação à responsabilidade da AMC e, via de conseqüência, da Requerente KIA Motors Corporation, frente ao fisco brasileiro, postos nestes termos: a requerente mantém-se vinculada às obrigações tributárias assumidas com a atividade da empresa denominada Asia Motors do Brasil S/A - AMB, em cuja participação detinha o controle acionário, controle esse mantido e não anulado pela decisão arbitral.

É o meu voto. 


\section{CERTIDÃO DE JULGAMENTO}

CORTE ESPECIAL

Número Registro: 2007/0156979-5

SEC 1/KR

Número Origem: 200500003685

PAUTA: $2804 / 2011$

JULGADO: 15/06/2011

\section{Relatora}

Exma. Sra. Ministra MARIA THEREZA DE ASSIS MOURA

Presidente da Sessão

Exmo. Sr. Ministro ARI PARGENDLER

Subprocurador-Geral da República

Exmo. Sr. Dr. HAROLDO FERRAZ DA NOBREGA

Secretária

Bela. VANIA MARIA SOARES ROCHA

\section{AUTUAÇÃO}

REQUERENTE : KIA MOTORS CORPORATION

ADVOGADO : EVANDRO LUÍS CASTELLO BRANCO PERTENCE E $\operatorname{OUTRO}(\mathrm{S})$

REQUERIDO : WASHINGTON ARMÊNIO LOPES

ADVOGADO : ARNOLDO WALD FILHO E OUTRO(S)

REQUERIDO : CHONG JIN JEON

ADVOGADO : DEFENSORIA PÚBLICA DA UNIÂO - CURADOR ESPECIAL

REQUERIDO : ROBERTO UCHÔA NETO

ADVOGADO : LUIZ ROBERTO DE ANDRADE NOVAES E OUTRO(S)

REQUERIDO : ÁSIA MOTORS DO BRASIL S/A

REQUERIDO : SET PARTICIPAÇÕES E EMPREENDIMENTOS S/A

ADVOGADO : DEFENSORIA PÚBLICA DA UNIÂO - CURADOR ESPECIAL

REQUERIDO : SET TRADING S/A

ADVOGADO : DEFENSORIA PÚBLICA DA UNIÃO - CURADOR 


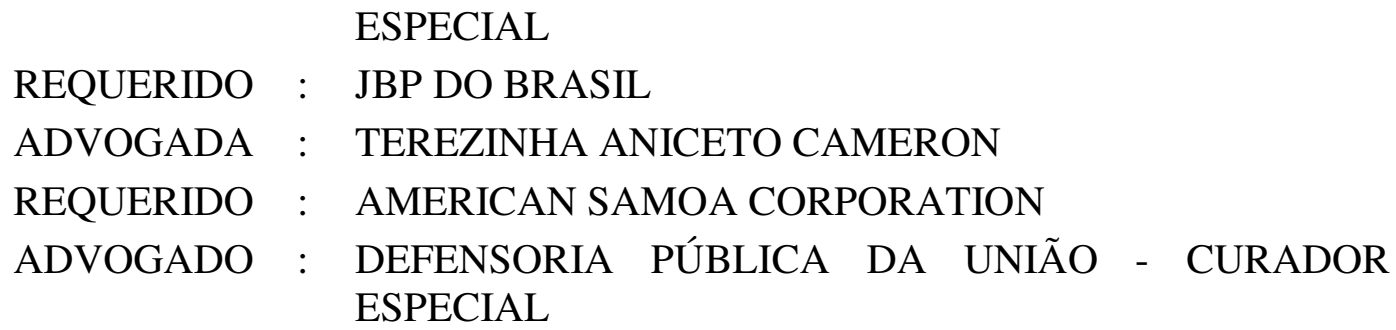

\section{CERTIDÃO}

Certifico que a egrégia CORTE ESPECIAL, ao apreciar o processo em epígrafe na sessão realizada nesta data, proferiu a seguinte decisão:

Prosseguindo no julgamento, após o voto-vista do Sr. Ministro Francisco Falcão deferindo em parte o pedido de homologação, no que foi acompanhado pelos votos dos Srs. Ministros Raul Araújo, Paulo de Tarso Sanseverino e Cesar Asfor Rocha, pediu vista a Sra. Ministra Nancy Andrighi.

Aguardam os Srs. Ministros Gilson Dipp, Laurita Vaz, João Otávio de Noronha, Massami Uyeda e Humberto Martins.

Não participaram do julgamento os Srs. Ministros Felix Fischer, Teori Albino Zavascki, Castro Meira e Arnaldo Esteves Lima.

Ausente, justificadamente, a Sra. Ministra Eliana Calmon.

SENTENÇA ESTRANGEIRA CONTESTADA No 1 - KR (2007/0156979-5) (f)

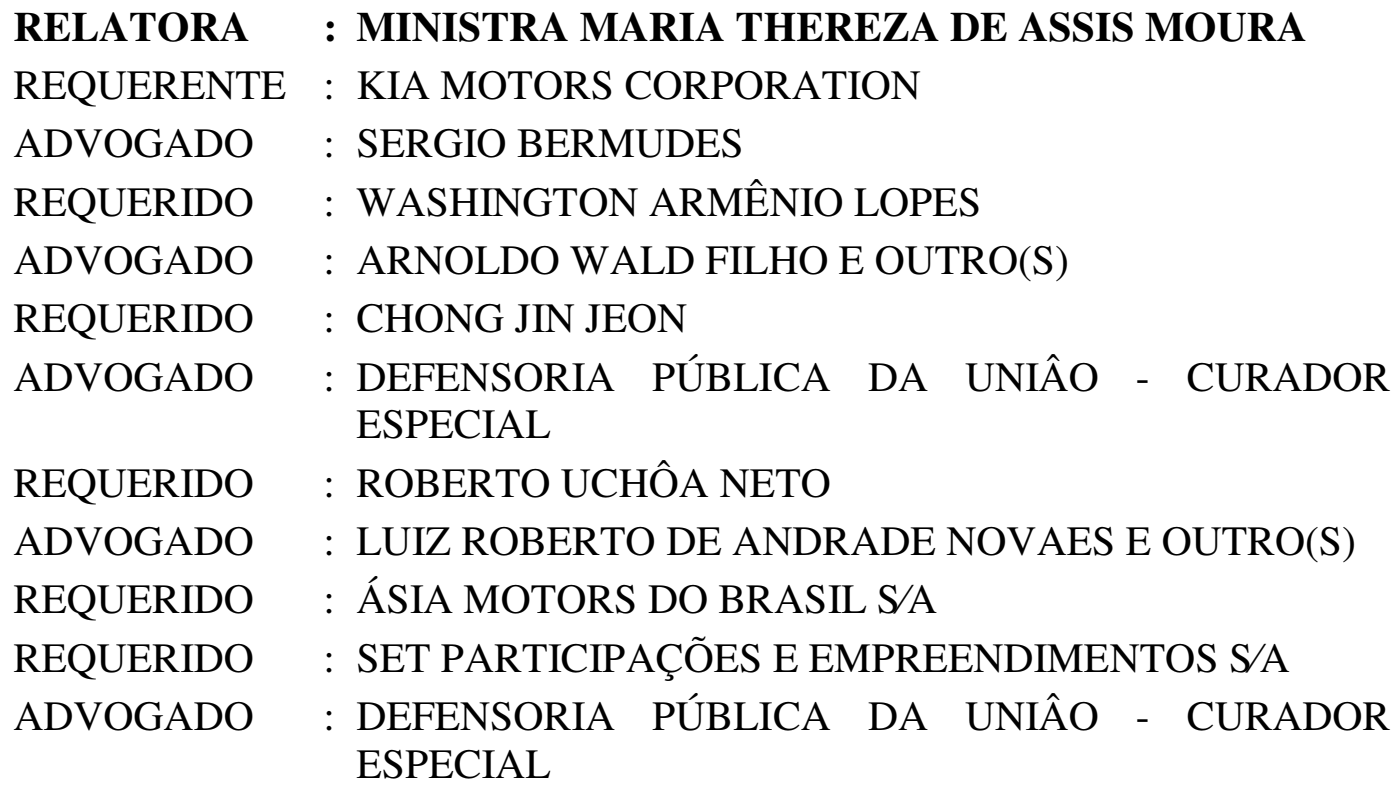




$\begin{array}{lllll}\text { REQUERIDO } & : \text { SET TRADING S/A } & & \\ \text { ADVOGADO } & : \text { DEFENSORIA PÚBLICA DA UNIÃO - CURADOR } \\ & \text { ESPECIAL } & & \\ \text { REQUERIDO } & : \text { JBP DO BRASIL } \\ \text { ADVOGADA } & : \text { TEREZINHA ANICETO CAMERON } \\ \text { REQUERIDO } & : \text { AMERICAN SAMOA CORPORATION } & \\ \text { ADVOGADO } & : \text { DEFENSORIA PÚBLICA DA UNIÃO - CURADOR } \\ & \text { ESPECIAL }\end{array}$

\section{VOTO-VISTA}

\section{A EXMA. SRA. MINISTRA NANCY ANDRIGHI:}

Cuida-se de pedido de homologação de sentença arbitral estrangeira proferida em Nova Iorque, Estados Unidos da América, pela Câmara de Comércio Internacional, formulado por KIA MOTORS CORPORATION, tendo como requeridos WASHINGTON ARMÊNIO LOPES, CHONG LIN JEON, ROBERTO UCHÔA NETO, ASIA MOTORS DO BRASIL S.A., JBP DO BRASIL, SET TRADING S.A., SET PARTICIPAÇÕES E EMPREENDIMENTOS S.A. E AMERICAN SAMOA CORPORATION.

Contestação: apresentada apenas pelo requerido WASHINGTON LOPES. A requerida JBP DO BRASIL constituiu patronos nos autos, mas não respondeu ao pedido de homologação. Os demais requeridos, não obstante regularmente citados, não compareceram aos autos, tendo-lhes sido nomeado curador, que apresentou contestação por negativa geral.

Em sua defesa, WASHINGTON LOPES alega incompetência do Tribunal Arbitral, afirmando: (i) a superação da cláusula compromissória contida no contrato de joint venture, por deliberações posteriores; (ii) que os temas levados à apreciação do Tribunal Arbitral não estavam abrangidos pela convenção arbitral; e (iii) ter havido a revogação tácita da cláusula compromissória, por ter a requerente previamente submetido a controvérsia à Justiça brasileira. Aduz, ainda, a ausência de indispensável participação das empresas American Samoa Corporation e Bambari International S.A. no processo arbitral.

Parecer do MPF: de lavra do o i. Subprocurador-Geral da República Dr. Edson Oliveira de Almeida, opina-se pela homologação parcial da sentença, rejeitandose os itens que tiverem sido objeto da ação de conhecimento ajuizada na Justiça Comum da Bahia, com decisão já transitada em julgado. 
Voto da Relatora: a i. Min. Maria Thereza de Assis Moura acolhe integralmente o parecer do MPF, homologando parcialmente a sentença arbitral, com exclusão dos seus itens 07 e 10 .

Revisados os fatos, decido.

A complexidade do caso exige que se proceda a uma breve descrição da relação negocial entabulada entre as partes, a servir de base para o deslinde da controvérsia.

A sentença arbitral que se pretende homologar teve por objeto contrato de joint venture celebrado pelas partes visando a expandir as vendas de veículos da ASIA MOTORS na América Latina. Em seu bojo foi inserida convenção arbitral e cláusula compromissória.

Na realidade, o joint venture reveste a condição de contrato principal, comumente denominado de guarda chuva, abrigando e ditando as regras de acordos paralelos e anexos, que orbitam em torno dele.

Entre esses anexos, encontra-se um acordo de acionistas, cuja cláusula 7.1 elege o foro da Comarca de São PauloSP para resolução de quaisquer dúvidas ou disputas, mas cuja cláusula 7.3 ressalva que "qualquer controvérsia ou reclamação que surja do exercício do direito dos acionistas, ou que a eles se relacione (...), será resolvida por arbitragem compulsória em conformidade com as Normas de Conciliação e Arbitragem da Câmara Internacional do Comércio (ICC)". (fls. 147/148).

No decorrer dessa relação comercial, surgiram desentendimentos entre as partes que culminaram na realização de assembleia geral extraordinária pela ASIA MOTORS DO BRASIL S.A. - empresa constituída para viabilizar a parceria - na qual foi aprovado um aumento de capital a ser imposto aos acionistas, em especial à requerente, a quem coube a subscrição de ações no valor de USD\$ 232.000.000,00.

Inconformada, a requerente ajuizou medida cautelar, distribuída para a $23^{\mathrm{a}}$ Vara Cível da Comarca de SalvadorBA, para sobrestar os efeitos das deliberações tomadas na mencionada assembleia geral extraordinária. Ato contínuo, ingressou com a respectiva ação principal, para anulação da assembleia. A decisão que julgou esses processos encontra-se transitada em julgado desde 07.12.2009.

Saliente-se, por oportuno, que em ambas as ações a requerente ressalvou expressamente que ao submeter-se à Justiça brasileira não estava renunciando à cláusula arbitral, esclarecendo que a via judicial somente estava sendo adotada em virtude da urgência das medidas e como única alternativa para efetivo resguardo dos seus direitos, visto que naquele momento ainda não havia sido constituído o Tribunal Arbitral competente para apreciar a controvérsia.

Em seguida, fazendo valer a ressalva supra, a requerente formulou pedido de procedimento arbitral junto à CCI, com fundamento em cláusula compromissória específica, suscitando a quebra do contrato de joint venture e seus anexos e 
postulando a condenação dos requeridos ao pagamento de indenizações, dando azo à sentença arbitral homologanda.

Esse, em síntese, o panorama fático que se revela essencial à análise da controvérsia.

Regida sobretudo pela contestação apresentada por WASHINGTON ARMÊNIO LOPES, a defesa dos requeridos suscita o não comparecimento das empresas American Samoa Corporation e Bambari International S.A. no processo de arbitragem. Insta registrar, porém, que a sentença arbitral consigna terem essas companhias sido regularmente citadas, vindo, no entanto, a caracterizar-se a sua revelia. Essa assertiva é confirmada pela correspondência de fl. 1.772, por meio da qual as referidas empresas demonstram ter conhecimento do procedimento arbitral mas se recusam a dele participar.

Dessa forma, foi devidamente preenchido o requisito do art. $5^{\circ}$, II, da Resolução $\mathrm{n}^{\circ}$ 09/2005, que fixa como requisito indispensável à homologação de sentença estrangeira terem as partes sido citadas ou haver-se legalmente verificado à revelia.

A contestação de WASHINGTON ARMÊNIO LOPES aduz, ainda, como tese central, a incompetência do Tribunal Arbitral, sustentando: (i) a superação da cláusula compromissória contida no contrato de joint venture, por deliberações posteriores; (ii) que os temas levados à apreciação do Tribunal Arbitral não estavam abrangidos pela convenção arbitral; e (iii) ter havido a revogação tácita da cláusula compromissória, por ter a requerente previamente submetido a controvérsia à Justiça brasileira.

Em primeiro lugar destaco que, ao contrário do que procura fazer crer a requerente, nada impede que, em sede de homologação de sentença arbitral estrangeira, se analise questões atinentes à competência do Tribunal Arbitral.

Com efeito, de acordo com o art. 38, IV e V, da Lei ${ }^{\circ}$ 9.307/96, o réu poderá obstar a homologação da sentença arbitral estrangeira se, entre outras coisas, demonstrar que "a sentença arbitral foi proferida fora dos limites da convenção de arbitragem, e não foi possível separar a parte excedente daquela submetida à arbitragem" ou que "a instituição da arbitragem não está de acordo com o compromisso arbitral ou cláusula compromissória”.

Igual conclusão se alcança a partir da análise conjugada dos arts. $5^{\circ}$, I, e $9^{\circ}$, da Resolução $n^{\circ}$ 09/2005 do STJ, que autoriza o réu a deduzir como matéria de defesa a incompetência da autoridade prolatora da sentença homologanda.

Outro não é o entendimento do STJ, conforme comprovam os seguintes precedentes: SEC 2.052DE, Corte Especial, Rel. Min. Castro Meira, DJe de 21.02.2008; e SEC 866/GB, Corte Especial, Rel. Min. Felix Fischer, DJ de 16.10.2006.

Perfeitamente possível, portanto, o exame da competência do Tribunal prolator da sentença arbitral, por compreender não apenas a análise da abrangência da 
cláusula compromissória, mas também da própria existência da convenção arbitral.

No que concerne à alegação de incompetência baseada na superação da cláusula compromissória existente no contrato de joint venture por deliberações posteriores, notadamente o acordo de acionistas e o contrato social, cumpre notar, antes de mais nada, que os joint ventures constituem contratos de colaboração comercial que refletem a íntegra dos entendimentos das partes acerca da operacionalidade do negócio que pretendem explorar conjuntamente.

Em outras palavras, o contrato de joint venture, também chamado de contrato guarda chuva ou contrato mãe, serve de base para a regulamentação dos demais acordos necessários à viabilização do negócio, corporificados nos denominados contratos satélites ou contratos filhotes.

Dessarte, para se extrair a real intenção das partes ao firmarem esse pacto de colaboração, deve-se ter em mente que as cláusulas e condições previstas no contrato de joint venture serviram de norte para a elaboração de todos os demais acordos, não sendo possível interpretar estes últimos isoladamente.

Assim, tendo as partes, após ampla discussão e induvidoso assessoramento jurídico e econômico que acompanha negociações desse porte, incluído no contrato de joint venture uma cláusula compromissória, é de se supor que estivessem externando sua manifestação de vontade no sentido de estarem dispostas a submeter ao juízo arbitral todas as desavenças surgidas, inclusive aquelas derivadas dos acordos anexos.

Nesse contexto, como bem pondera a i. Min. Relatora, não se mostra razoável admitir que, tendo inicialmente assumido uma proposta de convenção arbitral cheia, prevendo alargada competência do juízo arbitral, as partes logo em seguida decidissem revogá-la, sem qualquer referência ao próprio contrato de joint venture.

Além disso, não se pode perder de vista que, diante da sua natureza solene e do elevado grau de comprometimento que a convenção arbitral exige e estabelece entre as partes, a sua desconstituição impõe a presença de iguais condições, demonstrando-se inequivocamente a vontade das partes quanto ao seu efetivo desfazimento, circunstância que não se observa na espécie.

Inclusive, tamanha foi a preocupação do legislador em preservar a cláusula compromissória, que o art. $8^{\circ}$ da Lei $\mathrm{n}^{\circ} 9.307 / 96$ consagra a sua autonomia, ou seja, a referida cláusula é absolutamente autônoma em relação ao contrato no qual estiver inserida, possuindo ligação meramente instrumental com o objeto principal do negócio jurídico.

Daí decorre que eventual manifestação de vontade das partes modificando o negócio principal não afeta a cláusula compromissória. Mais do que isso, a autonomia da cláusula compromissória é corolário do princípio da kompetenzkompetenz, isto é, da competência sticto sensu do juízo arbitral - e não do Poder 
Judiciário - para resolução de qualquer discussão acerca do contrato principal, seus anexos e das alterações neles imprimidas.

Por outro lado, o art. 112 do CC/02 determina que, nas declarações de vontade, se atenda mais à intenção nelas consubstanciada do que ao sentido literal da linguagem. A exegese sistemática de todos os acordos celebrados pelas partes indubitavelmente aponta para a prevalência, sobre os demais, do contrato de joint venture, firmado com o claro propósito de reger a condução de toda a relação negocial, não sendo possível inferir a existência de julgamento extra petita pela Corte Arbitral.

No que tange à alegação de revogação tácita da cláusula compromissória, cumpre notar, em primeiro lugar, ter a requerente ressalvado, de forma expressa, que a utilização da via judicial derivava exclusivamente da urgência da medida e como única alternativa para efetivo resguardo dos seus direitos, visto que naquele momento ainda não havia sido constituído o Tribunal Arbitral competente para apreciar a controvérsia.

Não bastasse isso, inexistiu, por parte das requeridas, qualquer insurgência ou ressalva no âmbito dos processos judiciais, vindo a suscitar a suposta revogação da cláusula compromissória somente em sede de arbitragem. Esse comportamento não se coaduna com o princípio da boa-fé objetiva, a permear todas as relações contratuais.

Dessarte, impossível afirmar que o ajuizamento das ações judiciais, pela requerente, caracterizaria um ato manifesto de renúncia à cláusula compromissória, até porque, nos termos do art. 114 do $\mathrm{CCO} 2$, a renúncia se interpreta restritivamente.

A questão, porém, não se limita a essa perspectiva, devendo-se analisar, também, a eventual existência de concorrência de jurisdições.

De acordo com o art. 90 do CPC, a ação intentada frente a Tribunal estrangeiro não induz litispendência, nem impede a autoridade judiciária brasileira de conhecer da mesma causa e das que lhe são conexas. A regra, não obstante diga respeito à litispendência internacional, pode - e deve - estender-se às hipóteses de sentença arbitral estrangeira, que, nos termos do art. 475-N do CPC, detém status de título executivo judicial, exercendo, portanto, o mesmo grau de autoridade e coerção das demais sentenças estrangeiras.

Fixada essa premissa, é possível concluir que a existência de ação judicial em curso no Brasil, tendo por objeto controvérsia dirimida por sentença arbitral estrangeira, em princípio não impede a homologação desta, desde que sejam observados e respeitados o conteúdo de cada decisão e a respectiva coisa julgada.

Aliás, o próprio art. $22, \S 4^{\circ}$, da Lei $\mathrm{n}^{\circ} 9.30796$ faculta aos árbitros requerer ao órgão do Poder Judiciário que seria, originariamente, competente para julgar a causa, as medidas coercitivas ou cautelares que entender necessárias. 
Sendo assim, não cabe falar em incompetência da CCI para análise das questões que lhe foram submetidas, tampouco em julgamento extra petita por parte daquele Tribunal Arbitral, nem na revogação tácita da cláusula compromissória.

Entretanto, a questão atinente à concorrência de jurisdições exige a confrontação do teor das decisões proferidas no âmbito das ações judiciais aforadas pela requerente, já transitadas em julgado, com o conteúdo da sentença arbitral, eliminando-se eventual sobreposição, de sorte a preservar a coisa julgada.

Referidas medidas judiciais tiveram desfecho nesta Corte, pelo julgamento do REsp 649.711/BA, que declarou a nulidade das deliberações aprovadas na assembleia geral extraordinária que aprovou aumento de capital a ser imposto aos acionistas, em especial à requerente. $\mathrm{O}$ respectivo acórdão transitou em julgado em 07.12.2009.

Ocorre que a sentença arbitral homologanda, em seus itens 07 e 10, dispõe igualmente sobre a nulidade da mencionada assembleia e daquilo que foi nela aprovado, devendo, por isso, essa parte da decisão ser decotada.

Com efeito, considerando que a homologação visa justamente a possibilitar que sentença prolatada no exterior produza efeitos no Brasil, não se pode admitir a homologação da parte dessa sentença que já tenha sido objeto de decisão judicial transitada em julgado.

Aliás, a própria requerente afirma expressamente não ter "interesse em ver homologada questão que se encontra sob os efeitos da coisa julgada no território brasileiro, o que ocorre unicamente com os pedidos 7 e 10 do laudo arbitral" (fl. 1.762). A rigor, portanto, partiu da própria requerente a iniciativa de pleitear a homologação apenas parcial da sentença estrangeira, com exclusão dos itens 07 e 10.

Forte nessas razões, acompanho na íntegra o laborioso voto da i. Min. Relatora. 


\section{CERTIDÃO DE JULGAMENTO}

CORTE ESPECIAL

Número Registro: 2007/0156979-5

SEC 1/KR

Número Origem: 200500003685

PAUTA: $2804 / 2011$

JULGADO: 05/102011

\section{Relatora}

Exma. Sra. Ministra MARIA THEREZA DE ASSIS MOURA

Presidente da Sessão

Exmo. Sr. Ministro ARI PARGENDLER

Subprocurador-Geral da República

Exmo. Sr. Dr. HAROLDO FERRAZ DA NOBREGA

Secretária

Bela. VANIA MARIA SOARES ROCHA

AUTUAÇÃ̃o

REQUERENTE : KIA MOTORS CORPORATION

ADVOGADO : SERGIO BERMUDES

REQUERIDO : WASHINGTON ARMÊNIO LOPES

ADVOGADO : ARNOLDO WALD FILHO E OUTRO(S)

REQUERIDO : CHONG JIN JEON

ADVOGADO : DEFENSORIA PÚBLICA DA UNIÂO - CURADOR ESPECIAL

REQUERIDO : ROBERTO UCHÔA NETO

ADVOGADO : LUIZ ROBERTO DE ANDRADE NOVAES E OUTRO(S)

REQUERIDO : ÁSIA MOTORS DO BRASIL S/A

REQUERIDO : SET PARTICIPAÇÕES E EMPREENDIMENTOS S/A

ADVOGADO : DEFENSORIA PÚBLICA DA UNIÂO - CURADOR ESPECIAL

REQUERIDO : SET TRADING S/A 


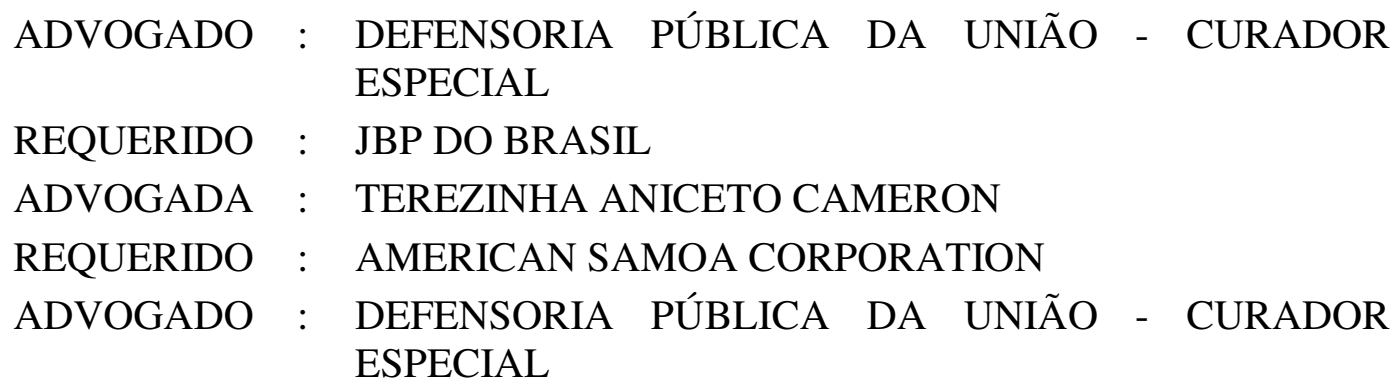

\section{CERTIDÃO}

Certifico que a egrégia CORTE ESPECIAL, ao apreciar o processo em epígrafe na sessão realizada nesta data, proferiu a seguinte decisão:

Prosseguindo no julgamento, após o voto-vista da Sra. Ministra Nancy Andrighi acompanhando o voto da Sra. Ministra Relatora, pediu vista antecipadamente o Sr. Ministro Massami Uyeda.

Aguardam os Srs. Ministros Gilson Dipp, Laurita Vaz, João Otávio de Noronha e Humberto Martins.

Não participaram do julgamento os Srs. Ministros Felix Fischer, Teori Albino Zavascki, Castro Meira e Arnaldo Esteves Lima.

Ausentes, justificadamente, os Srs. Ministros Cesar Asfor Rocha, Eliana Calmon e Francisco Falcão.

SENTENÇA ESTRANGEIRA CONTESTADA No 1 - KR (2007/0156979-5) (f)

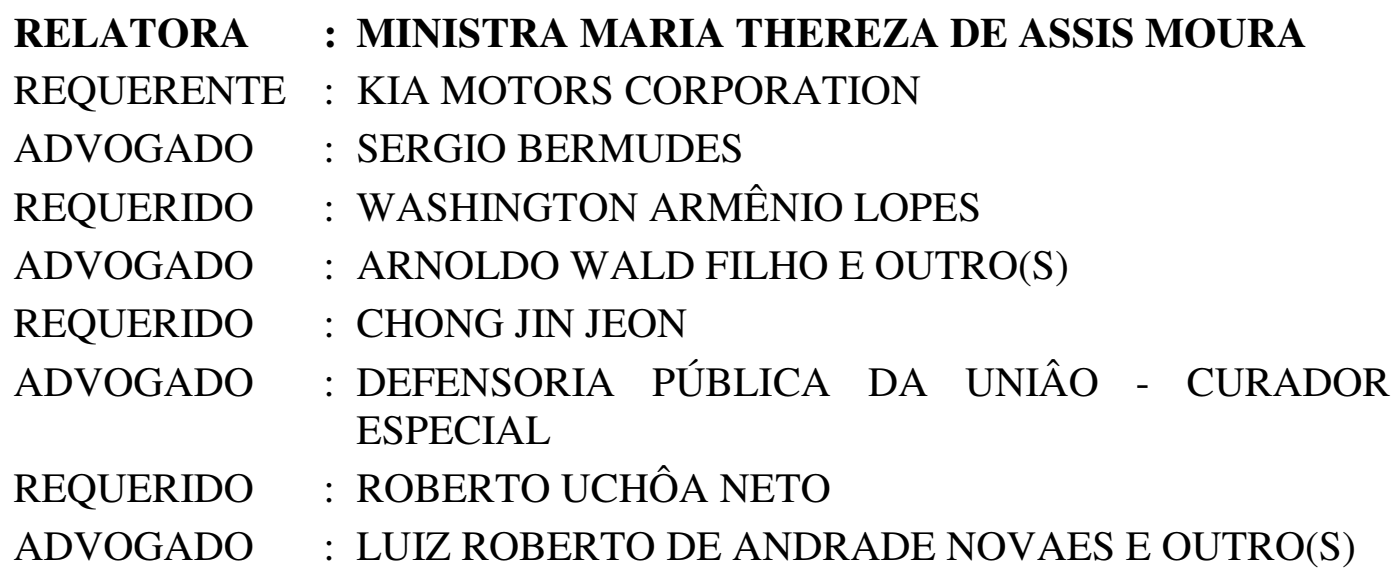




$\begin{array}{lllll}\text { REQUERIDO } & : \text { ÁSIA MOTORS DO BRASIL S/A } \\ \text { REQUERIDO } & : \text { SET PARTICIPAÇÕES E EMPREENDIMENTOS S/A } \\ \text { ADVOGADO } & \begin{array}{l}\text { DEFENSORIA PÚBLICA DA UNIÂO } \\ \text { ESPECIAL }\end{array} & \text { CURADOR } \\ \text { REQUERIDO } & : \text { SET TRADING S/A } & & \\ \text { ADVOGADO } & : \text { DEFENSORIA PÚBLICA DA UNIÃO } & \text { - CURADOR } \\ & \text { ESPECIAL } & & \\ \text { REQUERIDO } & : \text { JBP DO BRASIL } & & \\ \text { ADVOGADA } & : \text { TEREZINHA ANICETO CAMERON } \\ \text { REQUERIDO } & : \text { AMERICAN SAMOA CORPORATION } \\ \text { ADVOGADO } & : \text { DEFENSORIA PÚBLICA DA UNIÃO - CURADOR } \\ & \text { ESPECIAL }\end{array}$

\section{VOTO-VISTA}

O EXMO. SR. MINISTRO MASSAMI UYEDA:

Inicialmente, consigna-se que o processo em referência foi submetido ao julgamento da Corte Especial deste Superior Tribunal de Justiça, e, na sessão realizada em 05/102011, após o voto-vista da Sra. Ministra Nancy Andrighi, acompanhando o voto da Sra. Ministra Relatora, no sentido de deferir parcialmente o pedido de homologação da sentença estrangeira, pediu-se vista antecipadamente dos autos.

Cuida-se de pedido de homologação de sentença estrangeira arbitral, formulado por KIA MOTORS CORPORATION, tendo como requeridos WASHINGTON ARMÊNIO LOPES E OUTROS, e por objeto a decisão da lavra de Tribunal Arbitral, instituído na cidade de Nova Iorque.

Em razão da complexidade da discussão travada nos autos, será exposta uma breve síntese da controvérsia.

Os elementos dos autos dão conta de que a ASIA MOTORS COMPANY, empresa coreana de automóveis, firmou contrato de parceria (denominado joint venture) com os requeridos WASHINGTON ARMÊNIO LOPES E OUTROS, em 2406/1997, objetivando expandir a venda de veículos da ASIA MOTORS no Brasil e na América Latina (cf. cópia do contrato traduzido às fls. 75/172, volume 1).

Referido contrato continha, expressamente, nas cláusulas 14.3 a 14.5 (fls. 114/15, volume 1), a previsão de convenção de arbitragem (expressão que engloba tanto a cláusula compromissória quanto o compromisso arbitral). Previa, ainda, a criação de uma nova empresa (Asia Motors do Brasil), a ser constituída com o objetivo de regular a relação entre todos os envolvidos no contrato de parceria, contendo o contrato, inclusive, como anexos, minutas do Acordo de 
Acionistas e do Estatuto Social da empresa a ser criada, que posteriormente tornaram-se definitivos, nos exatos termos em que foram minutados.

Ressalte-se que, tanto no Acordo de Acionistas quanto no Estatuto Social da Asia Motors do Brasil, não constou a previsão de cláusula compromissória, tendo sido livremente eleito pelas partes, no Acordo de Acionistas, o Poder Judiciário do Brasil, mais especificamente o foro da Cidade de São Paulo, com renúncia a qualquer outro, para dirimir qualquer disputa decorrente do acordo (cf. cláusula 7.1, à fl. 146, volume 1), sendo que apenas as questões relacionadas a eventual opção de compra ou venda de ações estariam sujeitas à via arbitral.

Foi celebrado, também, entre a Asia Motors Company e a Asia Motors do Brasil, "contrato de cooperação técnica para Topic e Tower", por meio do qual a Asia Motors Company se comprometia a transferir tecnologia à Asia Motors do Brasil, o que permitiria a esta última construir uma fábrica de automóveis no Brasil (fls. 212/294, volume 2).

Em 2.3.1998, a recém constituída Asia Motors do Brasil realizou Assembléia Geral Extraordinária, onde os sócios aprovaram o aumento do capital social da companhia, imputando à Asia Motors Company a subscrição do capital social no valor aproximado de U\$232.000.000,00 (duzentos e trinta e dois milhões de dólares).

Em razão de tal deliberação, em 31/1/2000, a KIA MOTORS COMPORATION (sucessora da Asia Motors Company), ajuizou medida cautelar preparatória perante o r. Juízo de Direito da $23^{a}$ Vara Cível de SalvadorßBA, com o fim de sobrestar os efeitos das deliberações havidas na Assembléia Geral Extraordinária da Asia Motors do Brasil, tendo sido deferida a liminar e, na seqüência, proposta, em 29.2.2000, a ação principal, onde pleiteou-se a nulidade da referida Assembléia.

Essas ações resultaram no Recurso Especial n. 649.711/BA, julgado pela Terceira Turma deste Superior Tribunal de Justiça, que, por maioria de votos, conheceu e deu provimento ao apelo nobre, "para declarar a nulidade das deliberações aprovadas na assembléia geral extraordinária, objeto da presente ação, com a participação do Senhor Jong Kun Lee, julgando procedente a ação ordinária e a cautelar", tendo o decisum transitado em julgado em 7/12/2009.

Em 24/12/2001, a Kia Motors Corporation ingressou com pedido de procedimento arbitral perante a Câmara de Comércio Internacional (CCI), com fundamento na cláusula compromissória prevista no contrato de joint venture, suscitando, em síntese: a) violação dos contratos preliminar e definitivo de joint venture pelos acionistas brasileiros e pela Asia Motors do Brasil; b) nulidade da deliberação social ocorrida na Asia Motors do Brasil, no tocante ao aumento do capital social e ao boletim de subscrição que imputou à Kia Motors Corporation o aporte de U\$232 milhões de dólares americanos; e c) violação do acordo de cooperação técnica pela Asia Motors do Brasil (fls. 334/396).

Foi prolatada a sentença pelo Tribunal Arbitral (fls. 566841, volume 3, e fls. 842995, volume 4), que decidiu, em síntese, ter ocorrido violação ao contrato de 
joint venture e má-gestão da Asia Motors do Brasil pelos reclamados (exceto o de número 03), bem como declarou rescindido o contrato de joint venture e nulo o boletim de subscrição que impunha à Kia Motors Corporation a obrigação de integralizar o valor de aproximadamente U\$232.000.000,00 (duzentos e trinta e dois milhões de dólares), condenando, ainda, os reclamados (exceto o de número 03) a indenizarem a Kia Motors Corporation pelos prejuízos a ela causados.

Referido decisum é o objeto do presente pedido de homologação de sentença estrangeira.

Com a citação dos requeridos, WASHINGTON ARMÊNIO LOPES apresentou contestação (fls. 1.679/1.705, volume 7), alegando, em síntese, a existência de óbices ao pedido de homologação, quais sejam: i) ausência de citação das empresas "American Samoa Corporation" e "Bambari Internacional S. A." no procedimento arbitral; ii) ocorrência de renúncia tácita, pela Kia Motors Corporation, à cláusula compromissória prevista no contrato de joint venture, tanto pela existência de deliberações posteriores havidas entre as partes, quanto pela submissão prévia da controvérsia à análise do Poder Judiciário do Brasil; iii) não abrangência, pela convenção arbitral, dos temas submetidos à análise do Tribunal Arbitral de Nova Iorque.

Os interessados CHONG JIN JEON, ASIA MOTORS DO BRASIL S. A., SET PARTICIPAÇÕES, AMERICAN SAMOA CORPORATION E SET TRADING S. A. apresentaram contestação, por meio da Defensoria Pública da União, que contestou por negativa geral (fls. 1.54011 .542 e 1.824/1.827).

O interessado ROBERTO UCHÔA NETO apresentou concordância com o pedido de homologação (fls. 1.252/1.253).

A interessada JB DO BRASIL, citada por meio de carta de ordem, na pessoa do seu representante legal, não contestou o pedido (fls. 1.745/1.746).

A KIA MOTORS CORPORATION apresentou réplica às fls. 1.748/1.764, reiterando o pedido de homologação.

Por fim, o Ministério Público Federal ofereceu parecer, no sentido do deferimento do pedido de homologação (fls. 1.8541.857, volume 7).

Prestados referidos esclarecimentos, passa-se à análise dos requisitos necessários à procedência do pedido de homologação.

Na realidade, a sentença estrangeira encontra-se apta à homologação somente quando atendidos os requisitos dos arts. $5^{\circ}$ e $6^{\circ}$ da Resolução STJ n. 9/2005, quais sejam: (i) a sua prolação por autoridade competente; (ii) a devida ciência do réu nos autos da decisão homologanda; (iii) o seu trânsito em julgado; (iv) a chancela consular brasileira acompanhada de tradução por tradutor oficial ou juramentado; (v) a ausência de ofensa à soberania ou à ordem pública nacional.

É certo, outrossim, que, na homologação de sentença estrangeira, esta Corte Superior exerce juízo meramente delibatório, aferindo, apenas, se o pedido atende 
aos requisitos previstos no art. $5^{\circ}$ da Resolução n. 09/2005/STJ e se não fere o disposto no art. $6^{\circ}$ do mesmo ato normativo, sendo vedada a apreciação do mérito da sentença a ser homologada.

Em relação à alegação do requerido WASHINGTON, de que não teria havido a citação das empresas "American Samoa Corporation" e "Bambari Internacional S.A" no processo de arbitragem, concorda-se integralmente com o voto da eminente Ministra Relatora, porquanto, na própria sentença arbitral, há previsão de que as referidas empresas foram devidamente citadas, vindo, contudo, a tornarem-se revéis, o que afasta o óbice suscitado.

Da mesma forma, os requisitos do trânsito em julgado e da chancela consular brasileira acompanhada de tradução por tradutor oficial ou juramentado restaram comprovados pela farta documentação acostada aos autos do presente processo.

Contudo, em relação aos requisitos da prolação por autoridade competente e da ausência de ofensa à soberania ou à ordem pública nacional, discorda-se, data venia, do voto da eminente Ministra Relatora.

Com efeito.

Importante deixar assente que não se discute a possibilidade de o Poder Judiciário, sem adentrar na análise do mérito do litígio, examinar a competência do Tribunal Arbitral, uma vez que amplamente superada pela jurisprudência a regra tradicional alemã anteriormente vigente, conhecida como "KompetenzKompetenz", que previa que os árbitros detinham a competência exclusiva para decidir sobre sua própria competência, estando, inclusive, prevista no Regimento Interno deste Superior Tribunal de Justiça, a suscitação, pelo réu, como matéria de defesa, da incompetência da autoridade prolatora da decisão que constitui objeto do pedido de homologação.

Assentado o entendimento acima, o busílis da quaestio aqui agitada consiste em saber se: i) o Acordo de Acionistas e o Estatuto Social da Asia Motors do Brasil, ao modificarem e incorporarem cláusulas previstas no contrato de joint venture, passaram ou não a reger autonomamente as relações jurídicas existentes entre os contratantes; e ii) a ora requerente Kia Motors Corporation, ao submeter, à apreciação do Poder Judiciário do Brasil, em 31/01/2.000 (medida cautelar) e 29/02/2.000 (ação principal), questões relativas à condução dos negócios sociais pelos sócios brasileiros e às deliberações da Assembléia Geral Extraordinária da empresa Asia Motors do Brasil, havida em 2/3/1.998, teria, ou não, renunciado tacitamente à cláusula arbitral anteriormente pactuada no contrato de joint venture (celebrado em 24061.997), excluindo, portanto, referidas questões da apreciação dos árbitros.

Com a devida vênia ao voto da eminente Ministra Relatora, entende-se que a resposta é positiva para ambos os questionamentos.

Na verdade, embora tenha sido pactuada cláusula compromissória no contrato de joint venture e no contrato de cooperação técnica, prevendo a submissão de eventuais litígios à arbitragem, é certo que o Acordo de Acionistas e o Estatuto 
Social da Asia Motors previam solução diversa, qual seja, que eventuais disputas entre as partes contratantes - exceto no que se refere ao exercício do direito de compra e venda de ações -, fossem solucionadas pelo Poder Judiciário, com exclusão de qualquer outra autoridade.

Oportuno deixar assente, outrossim, que, embora não se olvide que o contrato de joint venture seja conhecido como "contrato guarda-chuva" - por servir de base para a regulamentação dos demais acordos necessários à viabilização do negócio , na hipótese dos autos, o seu teor foi integralmente incorporado ao Acordo de Acionistas, por expressa disposição das partes, sendo que o referido Acordo, por si só, passou a reger as relações jurídicas havidas entre as partes.

Logo, o contrato de joint venture firmado entre as partes se desnaturou, sendo incorporado por um contrato posterior, que, por ser mais amplo e abrangente, abandonou a sua característica de contrato acessório ou "contrato satélite".

A corroborar referida tese, veja-se, inclusive, que, em conformidade com os elementos dos autos, o Acordo de Acionistas, em determinadas cláusulas, previu alterações ao contrato de joint venture, modificando-o, indo além de suas previsões, ganhando autonomia própria e passando a regular, por conseqüência, a própria relação jurídica existente entre as partes, não podendo, assim, ser considerado um simples contrato acessório.

Ademais, a requerente Kia Motors Corporation renunciou tacitamente à via arbitral ao submeter ao Poder Judiciário, em 31/1/2.000 e 29.2.2000, respectivamente, as ações cautelar e principal, com o intuito de ver reconhecido o descumprimento do contrato de joint venture, já tendo havido, inclusive, o trânsito em julgado da matéria.

Relevante, no ponto, o fato de que, na medida cautelar, a Kia Motors Corporation ter exposto que a propositura de tal ação judicial não implicaria a renúncia expressa ou tácita à convenção de arbitragem anteriormente estabelecida no contrato de joint venture, fundamentando, também, que a cautelar seria preparatória de futuro procedimento arbitral.

Isso porque, obtido o provimento liminar e suspensos judicialmente os efeitos da deliberação havida na Assembléia Extraordinária da Asia Motors do Brasil, a Kia Motors Corporation não ingressou, como deveria, com procedimento arbitral, mas com a ação principal, perante o mesmo Juízo de Direito, fato que revela, sem dúvida, a sua intenção de renunciar ao Juízo arbitral, o que, repise-se, ocorreu tacitamente.

A propósito, cita-se recente precedente desta Corte Superior, no julgamento da SEC 826KR, relator Ministro Hamilton Carvalhido, DJ de 14/102.010, no sentido de indeferir o pedido de homologação de sentença arbitral estrangeira quando, embora pactuada cláusula compromissória, ficar comprovado que a autora/requerente submeta voluntariamente a questão ao crivo do Poder Judiciário, sendo este o caso dos autos. 
É importante a transcrição do seguinte trecho do acórdão, no que interessa à controvérsia, in verbis:

"De todo o exposto resulta que, não obstante a adoção da Justiça arbitral em cláusula compromissória, 'in casu', a própria autora se submeteu voluntariamente à competência da Justiça estatal, habilitando seu crédito nos autos de concordata preventiva deferida pela Justiça brasileira antes da prolação da sentença arbitral, assumindo regularmente a defesa do seu interesse, e ali vem buscando o recebimento do valor correspondente ao contrato mercantil que deu origem à decisão arbitral, impondo-se, dessa forma, indeferir o pedido de homologação da sentença arbitral estrangeira, pena de ofensa à soberania, nos termos do artigo $6^{\circ}$ da Resolução $n^{\circ} 9$, de 4 de maio de 2005, desta Corte de Justiça, 'verbis': 'Art. $6^{\circ}$ Não será homologada sentença estrangeira ou concedido exequatur a carta rogatória que ofendam a soberania ou a ordem pública.' Pelo exposto, indefiro o pedido de homologação da presente sentença estrangeira".

Assim, com o pronunciamento do Poder Judiciário Brasileiro, com trânsito em julgado - Resp n. , a se pretender homologar sentença estrangeira proferida após o trânsito em julgado da r. decisão judicial brasileira, há manifesta violação à soberania nacional, vulnerando-se o comando do artigo $1^{0}$, inciso I, da Constituição Federal de 1.988.

Constata-se, outrossim, que a Asia Motors do Brasil, que figurou como ré tanto na medida cautelar quanto na ação principal, também renunciou tacitamente à arbitragem, pois, acionada judicialmente, não alegou, como preliminar de contestação, a existência de convenção de arbitragem, concordando, portanto, que a solução da controvérsia se desse unicamente pelo Poder Judiciário.

Tal constatação torna-se mais evidente ainda pelo fato de que a Asia Motors do Brasil, ao ser acionada pela Kia Motors Corporation, perante o Tribunal Arbitral de Nova Iorque, prontamente alegou a incompetência do órgão arbitral para o julgamento da causa, eis que, segundo a concepção da Asia Motors do Brasil, restava claro que as partes, anteriormente, haviam renunciado à cláusula arbitral e apontado o Poder Judiciário como o único Órgão competente para dirimir eventuais dúvidas e solucionar eventuais litígios surgidos no decorrer das relações entre os sócios.

Desse modo, como o litígio que originou a sentença arbitral - objeto do presente pedido de homologação - não cuidou de questões atinentes à compra e venda de ações, mas sim de questões intrinsecamente relacionadas ao Acordo de Acionistas, e, considerando que o referido Acordo passou a regular as relações jurídicas havidas entre as partes, incorporando e alterando o próprio contrato de joint venture, bem como que a Kia Motors Corporation e a Asia Motors do Brasil renunciaram tacitamente à cláusula compromissória, conclui-se que o Poder Judiciário do Brasil é o único competente para solucionar as controvérsias submetidas ao Tribunal Arbitral.

Assim, a se pretender homologar sentença estrangeira proferida após o pronunciamento do Poder Judiciário brasileiro (Recurso Especial n. 649.711/BA), transitado em julgado em 7/12/2.009, há manifesta violação à soberania nacional, 
vulnerando-se o comando do art. $1^{\circ}$, inciso I, da Constituição Federal de 1.988, que assim dispõe, in verbis:

"Art. $1^{o}$ A República Federativa do Brasil, formada pela união indissolúvel dos Estados e Municípios e do Distrito Federal, constitui-se em Estado Democrático de Direito e tem como fundamentos:

I - a soberania;

$(\ldots)^{\prime \prime}$

Por todo o exposto, dissente-se da eminente Ministra Relatora e vota-se no sentido de indeferir o pedido de homologação de sentença estrangeira arbitral, condenando a requerente ao pagamento de honorários advocatícios no valor de $\mathrm{R} \$ 20.000,00$ (vinte mil reais).

É o voto.

MINISTRO MASSAMI UYEDA 


\section{CERTIDÃO DE JULGAMENTO}

CORTE ESPECIAL

Número Registro: 2007/0156979-5

SEC 1/KR

Número Origem: 200500003685

PAUTA: $2804 / 2011$

JULGADO: 19/102011

\section{Relatora}

Exma. Sra. Ministra MARIA THEREZA DE ASSIS MOURA

Presidente da Sessão

Exmo. Sr. Ministro ARI PARGENDLER

Subprocurador-Geral da República

Exmo. Sr. Dr. HAROLDO FERRAZ DA NOBREGA

Secretária

Bela. VANIA MARIA SOARES ROCHA

AUTUAÇÃ̃o

REQUERENTE : KIA MOTORS CORPORATION

ADVOGADO : SERGIO BERMUDES

REQUERIDO : WASHINGTON ARMÊNIO LOPES

ADVOGADO : ARNOLDO WALD FILHO E OUTRO(S)

REQUERIDO : CHONG JIN JEON

ADVOGADO : DEFENSORIA PÚBLICA DA UNIÂO - CURADOR ESPECIAL

REQUERIDO : ROBERTO UCHÔA NETO

ADVOGADO : LUIZ ROBERTO DE ANDRADE NOVAES E OUTRO(S)

REQUERIDO : ÁSIA MOTORS DO BRASIL S/A

REQUERIDO : SET PARTICIPAÇÕES E EMPREENDIMENTOS S/A

ADVOGADO : DEFENSORIA PÚBLICA DA UNIÂO - CURADOR ESPECIAL

REQUERIDO : SET TRADING S/A 


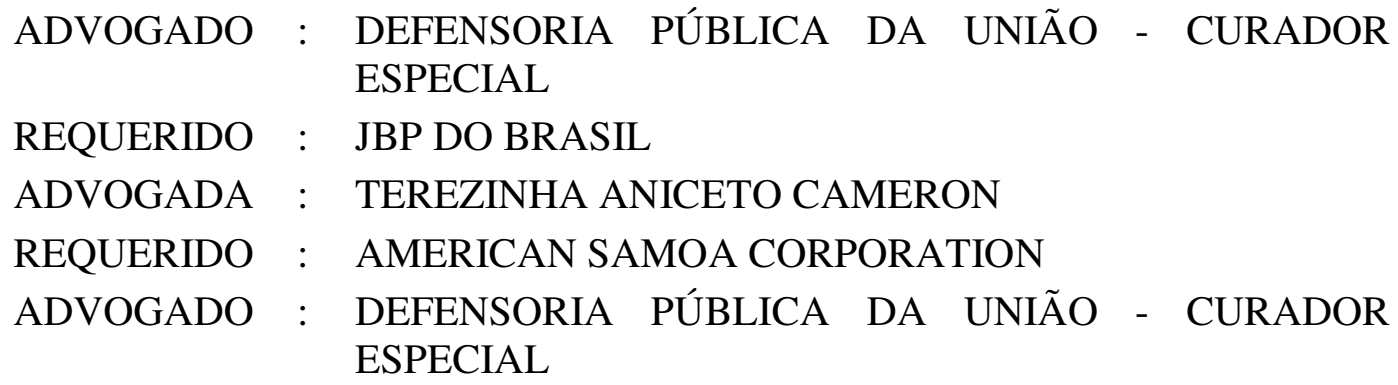

\section{CERTIDÃO}

Certifico que a egrégia CORTE ESPECIAL, ao apreciar o processo em epígrafe na sessão realizada nesta data, proferiu a seguinte decisão:

Prosseguindo no julgamento, após o voto-vista do Sr. Ministro Massami Uyeda indeferindo o pedido de homologação, e os votos dos Srs. Ministros Gilson Dipp, Laurita Vaz e Humberto Martins, acompanhando o voto da Sra. Ministra Relatora, a Corte Especial, por maioria, deferiu parcialmente o pedido de homologação, nos termos do voto da Senhora Ministra Relatora. Vencido o Sr. Ministro Massami Uyeda.

Os Srs. Ministros Raul Araújo, Mauro Campbell Marques, Paulo de Tarso Sanseverino, Cesar Asfor Rocha, Gilson Dipp, Francisco Falcão, Nancy Andrighi, Laurita Vaz e Humberto Martins votaram com a Sra. Ministra Relatora.

Não participaram do julgamento os Srs. Ministros Felix Fischer, Teori Albino Zavascki, Castro Meira e Arnaldo Esteves Lima.

Ausentes, justificadamente, os Srs. Ministros Cesar Asfor Rocha, Eliana Calmon, Francisco Falcão e João Otávio de Noronha.

Documento: 1056429 Inteiro Teor do Acórdão ～- DJe: 01/02/2012 